\title{
DETERMINAÇÃO E AVALIAÇÃO DE FATORES QUE AFETAM A PRODUTIVIDADE DE VACAS LEITEIRAS: ASPECTOS SANITÁRIOS E REPRODUTIVOS
}

\author{
CARLOS HUMBERTO CORASSIN
}

Tese apresentada à Escola Superior de Agricultura "Luiz de Queiroz”, Universidade de São Paulo, para obtenção do título de Doutor em Agronomia, Área de Concentração: Ciência Animal e Pastagens.

P I R A C I C A B A

Estado de São Paulo - Brasil

Janeiro - 2004 


\section{DETERMINAÇÃO E AVALIAÇÃO DE FATORES QUE AFETAM A PRODUTIVIDADE DE VACAS LEITEIRAS: ASPECTOS SANITÁRIOS E REPRODUTIVOS}

\section{CARLOS HUMBERTO CORASSIN}

Médico Veterinário

Orientador: Prof. Dr. PAULO FERNANDO MACHADO

Tese apresentada à Escola Superior de Agricultura "Luiz de Queiroz”, Universidade de São Paulo, para obtenção do título de Doutor em Agronomia, Área de Concentração: Ciência Animal e Pastagens.

P I R A C I C A B A

Estado de São Paulo - Brasil

Janeiro - 2004 


\section{Dados Internacionais de Catalogação na Publicação (CIP)}

DIVISÃO DE BIBLIOTECA E DOCUMENTAÇÃO - ESALQ/USP

\section{Corassin, Carlos Humberto}

Determinação e avaliação de fatores que afetam a produtividade de vacas

leiteiras: aspectos sanitários e reprodutivos / Carlos Humberto Corassin. -

Piracicaba, 2004

$101 \mathrm{p}$.

Tese (doutorado) - Escola Superior de Agricultura Luiz de Queiroz, 2004.

Bibliografia.

1. Produtividade animal 2. Reprodução animal 3. Saúde animal 4. Vaca leiteira I. Título

CDD 636.214

\section{"Permitida a cópia total ou parcial deste documento, desde que citada a fonte - $\mathrm{O}$ autor"}




\section{Dedicatória}

Dedico aos meus pais, Wilson, pelo exemplo de caráter, dignidade e trabalho e Claudete, pelo amor, confiança e compreensão; ao meu irmão Wilson, pela grande amizade e carinho.

Minha eterna gratidão 


\section{Agradecimentos}

À Fundação de Amparo à Pesquisa do Estado de São Paulo (FAPESP), pelo auxilio financeiro e por acreditar em nosso projeto.

À Escola Superior de Agricultura "Luiz de Queiroz" (ESALQ), pela oportunidade de realização desta pós-graduação.

Ao Professor Orientador Dr. Paulo Fernando Machado, pelo apoio e orientação sempre tão prestativa.

Aos professores Aleksandrs Spers, José Luiz Moraes Vasconcelos e Wilson Roberto Mattos, por participarem da minha banca de qualificação contribuindo de forma a engrandecer este trabalho.

Aos professores e funcionários do Departamento de Zootecnia, por tornarem possivel e agradável a minha estada nesse curso.

Ao colega de pós-graduação e médico veterinário Arlei Coldebella, pelo inestimável auxílio na análise estatística deste trabalho e amizade.

À equipe da Fazenda Colorado, em especial ao proprietário Lair Antônio de Souza e aos médicos veterinários Antônio Carlos Sobreira e Sérgio Soriano, que permitiram e viabilizaram a execução deste trabalho na fazenda e foram incansáveis no auxílio diário das tarefas. 
Aos funcionários e amigos da Clínica do Leite, por seu trabalho árduo que dedicam a essa instituição, em especial ao Laerte e ao João Carlos pelo envolvimento conciso a este trabalho.

À MCassab, em especial à médica veterinária Andréa S. Paulin, e à FMVZ-USP, na pessoa do Prof. Dr. Paulo Henrique Mazza Rodrigues, pelo auxílio com as análises bromatológicas deste experimento.

À minha tia, a Prof. Dra. Maria Luiza Corassin, por auxiliar na verificação ortográfica e gramatical deste material e por me incentivar na vida acadêmica.

A todos os professores e funcionários do Departamento de Zootecnia, por tornarem possivel a minha estada nesse curso.

Aos meus colegas de pós-graduação Arlei, Décio, Karyne, Laerte, Paula, Paulo Garcez e Rafael, pela amizade e companheirismo.

À toda minha família, fonte de alegria, segurança e força.

Ao meu grande protetor Santo Expedito, que sempre me acompanha, ajudando a superar as horas dificeis.

Enfim, a todos que de alguma forma colaboraram com este trabalho, o meu sincero... 


\section{SUMÁRIO}

Página

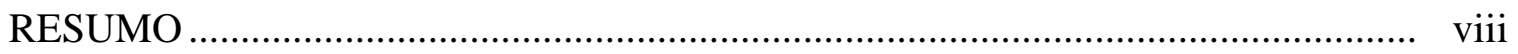

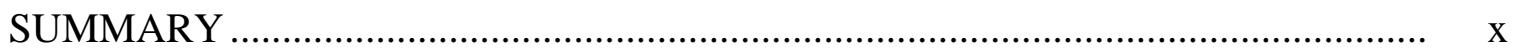

1 INTRODUÇÃ

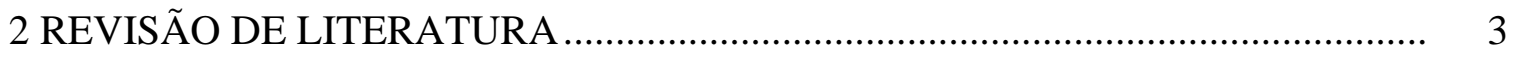

2.1 Produção de leite ............................................................................................. 3

2.1.1 Relação da produção de leite com a sanidade animal .......................................... 3

2.1.2 Relação da produção de leite com a reprodução ................................................ 5

2.2 Os componentes do leite associados à sanidade e reprodução............................... 7

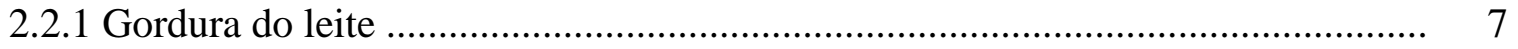

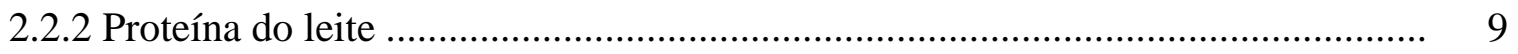

2.2.3 Nitrogênio uréico do leite (MUN) ............................................................... 10

2.3 Efeitos do estresse térmico sobre reprodução e produção....................................... 13

2.3.1 Efeitos do estresse térmico sobre a reprodução ................................................. 14

2.3.2 Efeitos do estresse térmico sobre a produção leiteira .......................................... 19

2.4 Sanidade (Desordens sanitárias do periparto) …................................................ 21

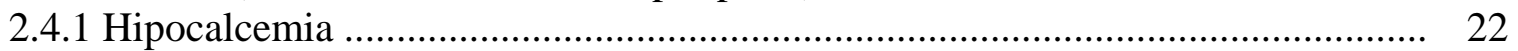

2.4.2 Retenção de placenta............................................................................... 24

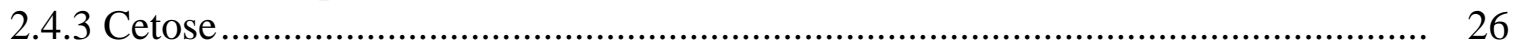

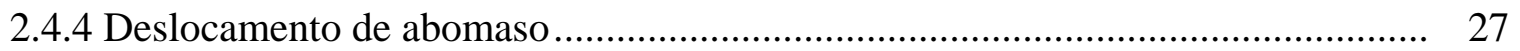

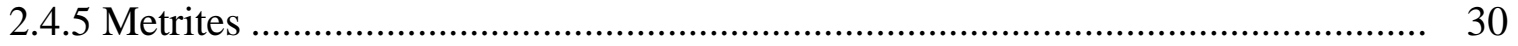

2.5 Efeitos do escore de condição corporal sobre a produção, reprodução e sanidade... 32

2.5.1 Escore de condição corporal e produção de leite ................................................ 33

2.5.2 Escore de condição corporal e reprodução........................................................ 36

2.5.3 Escore de condição corporal e sanidade.......................................................... 38

3 IMPORTÂNCIA DAS DESORDENS DO PERIPARTO E SEUS FATORES DE RISCO SOBRE A PRODUÇÃO DE LEITE DE VACAS HOLANDESAS ............... 40

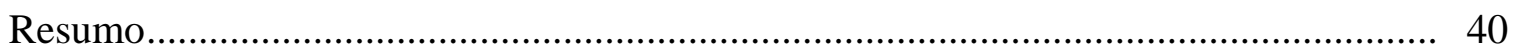




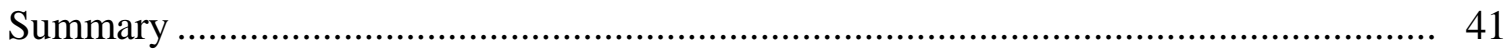

3.1 Introdução.............................................................................................................. 41

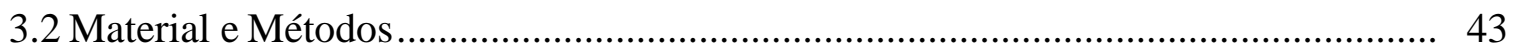

3.2.1 Animais e instalações...................................................................................... 43

3.2.2 Alimentação e monitoramento nutricional........................................................... 44

3.2.3 Coleta de dados experimentais....................................................................... 47

3.2.3.1 Produção de leite ........................................................................................ 47

3.2.3.2 Desordens sanitárias................................................................................. 47

3.2.3.3 Escore de condição corporal (ECC)........................................................... 48

3.2.4 Análise estatística..................................................................................... 49

3.3 Resultados e Discussão....................................................................................... 49

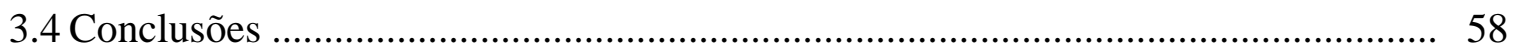

4 DETERMINAÇÃO DE FATORES DE RISCO ASSOCIADOS A FALHAS DE CONCEPÇÃO AO PRIMEIRO SERVIÇO EM VACAS LEITEIRAS DE ALTA

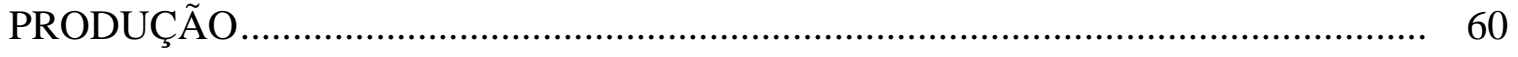

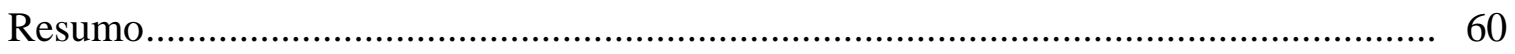

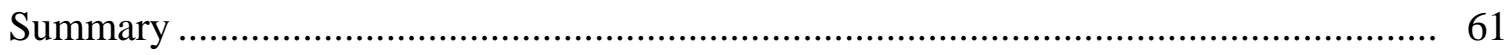

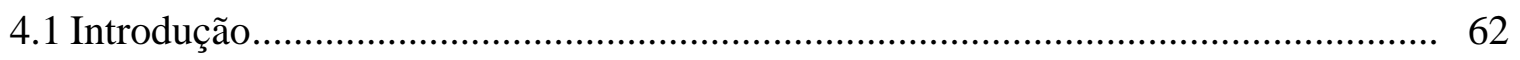

4.2 Material e Métodos ............................................................................................ 64

4.2.1 Seleção de animais ........................................................................................... 64

4.2.2 Alimentação e monitoramento nutricional............................................................. 65

4.2.3 Coleta de dados experimentais.................................................................... 67

4.2.3.1 Produção e composição do leite..................................................................... 68

4.2.3.2 Desordens sanitárias................................................................................. 68

4.2.3.3 Escore de condição corporal .......................................................................... 69

4.2.4 Análise estatística......................................................................................... 70

4.3 Resultados e Discussão ....................................................................................... 70

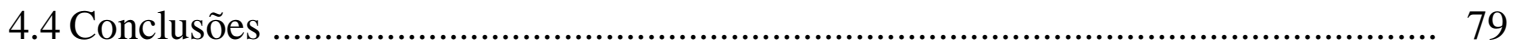

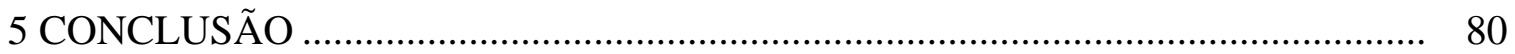

REFERÊNCIAS BIBLIOGRÁFICAS................................................................. 81 


\title{
DETERMINAÇÃO E AVALIAÇÃO DE FATORES QUE AFETAM A PRODUTIVIDADE DE VACAS LEITEIRAS: ASPECTOS SANITÁRIOS E REPRODUTIVOS
}

\author{
Autor: CARLOS HUMBERTO CORASSIN \\ Orientador: Prof. Dr. PAULO FERNANDO MACHADO
}

\section{RESUMO}

O objetivo deste trabalho foi determinar e avaliar os fatores sanitários e reprodutivos capazes de afetar a produtividade de vacas leiteiras. Pesquisou-se por meio de dois estudos correlacionais os efeitos de ocorrências sanitárias no periparto e seus respectivos fatores de risco sobre a produção de leite no pico e aos 305 dias em lactação, e os fatores de riscos para falhas na concepção ao primeiro serviço pós-parto (CPS). Para concretizar o objetivo deste trabalho, foram coletados mensalmente durante os anos de 2001 e 2002 dados de um rebanho comercial de vacas leiteiras de raça holandesa, localizado no Estado de São Paulo. Para a realização do primeiro estudo foram usadas 15.613 observações e para a análise estatística dos dados foram utilizadas a regressão logística e a análise de regressão múltipla. Os resultados obtidos nestas análises demonstraram que as doenças do periparto e seus fatores de risco afetaram a produção de leite com diferentes efeitos em função do número de lactações, exigindo desta maneira maior cuidado com adoção de medidas profiláticas para serem evitadas doenças e para maximizar a produção de leite dos animais. Foram usadas no segundo estudo 
13.594 observações e os dados foram analisados estatisticamente por meio de regressão logística, calculando-se a razão das chances no isolamento dos fatores de risco e na associação entre os riscos para sucesso ou falha na CPS. Os resultados obtidos indicaram que os principais fatores de risco foram o número da lactação, a época do ano ao primeiro serviço, a ocorrência de doenças no periparto, a relação entre as porcentagens de gordura e proteína do leite (RGP) e as alterações no escore de condição corporal (ECC). Os animais de primeira lactação apresentaram maior chance de sucesso ao primeiro serviço do que os animais multíparos. As vacas cobertas no período do inverno apresentaram, aproximadamente, cinco vezes mais chances de CPS do que as vacas cobertas no verão. Os animais que apresentaram doenças no periparto tiveram menor sucesso de concepção que os animais sadios. Os animais que apresentaram melhor condição ruminal, determinada pela RGP, principalmente durante o período de verão, tiveram melhor concepção do que os animais com RGP reduzida no verão. O ECC adequado nas diferentes fases produtivas das vacas (secagem, parto e cobertura) demonstrou ser uma importante ferramenta para identificar as vacas com risco de insucesso na concepção ao primeiro serviço. 


\title{
EVALUATION AND DETERMINATION OF FACTORS INFLUENCING DAIRY COWS PRODUCTIVITY: HEALTH AND REPRODUCTIVE ASPECTS
}

\author{
Author: CARLOS HUMBERTO CORASSIN \\ Adviser: PhD PAULO FERNANDO MACHADO
}

\section{SUMMARY}

These studies evaluate health and reproductive factors affecting dairy cows' productivity. Through correlation studies were evaluated health occurrences and risk factors during peripartum for milk production at peak, after 305 days of lactation and conception failures on first service pos-partum (CFS). Using a commercial herd of “dairy holsteins cows” located in São Paulo state - Brazil, data were collect in 2001 and 2002. On the first study were used 15,613 observations, the statistical analyses data were processed on logistic regression and multiple regression analyses. The analyses showed that peripartum diseases and risk factors directly affected milk production, with different effects based on lactations times, requesting extra care on prophylactics to avoid diseases and improve milk production. On the second study were used 13,594 observations, the statistical analyses data were processed on logistic regression calculating chances ratio on risk factors isolation and risk factors association to success or failure on first service pos-partum. Results indicated as mainly risks factors: lactation times, year period that first service occurred, peripartum diseases, body score condition (BSC), milk protein and fat ratio (PFR). First lactation animals presented more chance of success to the first service than multiparous. Cows inseminated during winter time showed 5 times more chances of CFS than ones inseminated on summer time. Animals 
with peripartum diseases had less conception success than healthy ones. Cows with better rumminal condition (FPR) had a much better conception than ones with lower FPR. The correct BSC on different productive steps (dry-off, calving and breeding) showed to be an important tool to identify animals with higher risks of failure on first service conception. 


\section{INTRODUÇÃO}

A pecuária leiteira é uma atividade economicamente desafiante, na qual, falhas podem causar prejuízos, ocasionando até a retirada do produtor da atividade.

A manutenção na atividade depende basicamente da eficiência do sistema de produção, que objetiva obter a maior produtividade com o menor custo possível. Para que a atividade seja rentável é necessário estar atento aos inúmeros fatores que podem ocasionar prejuízos; portanto, é necessário determinar os principais fatores indicadores da eficiência do sistema. Neste estudo serão avaliados aspectos relacionados a reprodução e sanidade, dentre os principais fatores que afetam a produtividade da atividade leiteira.

O monitoramento é a ferramenta que permite identificar os pontos problemáticos e os resultados das eventuais correções. É preciso, antes de iniciar um trabalho, verificar o que acontece, como acontece e em que proporções pode afetar a atividade, para que posteriormente sejam estabelecidos parâmetros e traçadas metas que possam ser realmente realizáveis.

A reprodução e a sanidade podem ser monitoradas de diversas formas e sofrem a interferência de inúmeros fatores intrínsecos ou não à vaca. Devido à complexidade destas determinações e à falta de estudos, principalmente nacionais, abordando dados sanitários, reprodutivos e produtivos de vacas com alta produção leiteira, decidiu-se estudar esses dois fatores, intimamente ligados e de extrema importância:

$\Rightarrow$ A sanidade (avaliando a lactação em função das doenças do parto);

$\Rightarrow$ A reprodução (determinando os fatores de podem afetar a concepção à $1^{\text {a }}$ cobertura.); 
O produtor e o veterinário poderão combater pontualmente as causas dos problemas sanitários se for possível determinar quais são as doenças que afetam a produção leiteira, quantificando as perdas causadas, para obter maior sucesso no controle sanitário do rebanho. Poderá ainda estimar o valor a ser investido em programas sanitários e avaliar se este investimento será recuperado com a futura produção de leite.

O mesmo poderá também ser feito em relação à reprodução, determinando quais os fatores de risco para concepção à $1^{\mathrm{a}}$ cobertura. Isolando-se os fatores que proporcionam as perdas na reprodução, ficará muito mais fácil a adoção de medidas técnicas e administrativas que visem diminuir as deficiências na reprodução do rebanho.

O trabalho nestas duas áreas cruciais da atividade leiteira facilita as ações dos produtores, veterinários e consultores, fornecendo orientação específica para soluções de cada um dos problemas, permitindo melhorar a produtividade nos rebanhos brasileiros. 


\title{
2 REVISÃO DE LITERATURA
}

\author{
2.1 Produção de leite
}

\subsubsection{Relação da produção de leite com a sanidade animal}

Há muito tempo o exame da questão relativa ao efeito do aumento da produtividade leiteira estar associado com um risco maior de ocorrência de doenças tem sido feito em diversos estudos, destacando-se o trabalho de alguns autores (Erb \& Grohn, 1988, Grohn et al., 1989, 1990, 1995, Heuer et al., 1999; Pryce et al., 1997 e 1998; Shanks et al., 1978 e Uribe et al., 1995). Contudo, as respostas a esta questão tem sido consideradas bastante vagas (Erb, 1987; Grohn et al., 1995 e Uribe et al., 1995), além de serem encontradas na literatura afirmações contraditórias (Rajala \& Grohn, 1998a).

Alguns autores conseguiram evidenciar maior incidência de doenças relacionadas com o aumento na produção leiteira (Aeberhard et al., 2001). Verificou-se que desordens metabólicas, clínicas ou subclínicas, mesmo quando discretas, causam freqüentemente diminuições na produção de leite (Erb et al., 1985).

Erb et al. (1981 e 1985), Dohoo et al. (1984) e Dohoo \& Martin (1984a e 1984b) investigaram os efeitos diretos e indiretos das doenças sobre a produção de leite. Os efeitos diretos referem-se às perdas ocorridas durante a lactação, após uma única ocorrência de doença. Os efeitos indiretos foram resultado do aumento nos riscos da recorrência após a primeira doença, ou devido ao efeito negativo de algumas doenças sobre a reprodução. 
Vários estudos apontam que a produção de leite corrigida para 305 dias de vacas pertencentes a rebanhos produtores de grande quantidade de leite foi afetada quando os animais sofreram doenças clínicas e/ou desordens reprodutivas (Dohoo \& Martin, 1984b; Erb et al., 1981 e 1985; Lucey et al., 1986 e Rowlands \& Lucey, 1986).

Deluyker et al. (1991), estudando um rebanho com produção média de 10.900 kg/leite/lactação, observaram que a produção de leite dos animais foi significativamente reduzida devido a ocorrência de casos de deslocamento de abomaso, mastite clínica, metrites primária e cetose.

Poucos estudos nacionais abordam o assunto. Em um estudo realizado no Estado de São Paulo, Cassoli et al. (2000) não encontraram diferenças entre as vacas acometidas por alguma doença do periparto ou aquelas totalmente saudáveis em relação a tais doenças para a produção de leite aos 305 dias, sendo este resultado indiferente, tanto para primíparas, quanto para multíparas. Quanto ao pico de produção de leite, as vacas multíparas que apresentaram alguma doença tiveram pico inferior ao das vacas não doentes.

Erb (1987) afirma que vários autores negaram que a elevação na incidência de doença esteja relacionada à crescente produção de leite (Bigras-Poulin et al., 1990; Erb, 1987; Grohn et al., 1995); para eles, como a secreção de leite tem alta prioridade metabólica, sendo mantida claramente às custas de outros processos reprodutivos e metabólicos, o esforço metabólico a que o animal é submetido, para que a produção seja alcançada, pode ocasionar uma maior freqüência das doenças (Bauman \& Currie, 1980).

Grohn et al. (1995) comentam que há falta de uma correlação demonstrável entre a produção de leite e a incidência de doença, servindo como uma possível indicação de que vacas mais produtivas não sejam necessariamente mais suscetíveis a doença, contanto que o manejo e a nutrição satisfaçam as necessidades biológicas aumentadas. 


\subsubsection{Relação da produção de leite com a reprodução}

O parto é acompanhado por mudanças no metabolismo de lipídios, carboidratos, proteínas e minerais, de forma a sustentar a produção de leite, direcionando as prioridades metabólicas para a produção de leite e não para a reprodução (Smith et al., 1981).

Vários estudos têm avaliado a correlação entre altas produções de leite e a reprodução de vacas leiteiras, apresentando resultados conflitantes.

Sargeant et al. (1998) sugerem que vacas com alta produção de leite (mais especificamente, do que vacas que são grandes produtoras de proteína) estão associadas a reduções no desempenho reprodutivo.

Vários estudos indicaram que a seleção genética para produção ocasionou declínio na fertilidade, determinando uma correlação desfavorável entre produção de leite e fertilidade (Hoekstra et al., 1994; Pryce et al., 1997, 1998, 2000).

Porém uma das explanações mais sensatas, baseada na revisão de vários trabalhos científicos, para explicar o efeito de altas produções leiteiras sobre a função reprodutiva, estabelece que é a ocorrência de uma deficiência energética severa no período do pós-parto, a qual proporciona um balanço energético negativo e conseqüentes alterações metabólicas, que pode ter efeito direto ou indireto sobre o sistema reprodutivo da vaca.

O atraso no reinicio da atividade ovariana após o parto está também associado à baixa ingestão de matéria seca (Hansen et al., 1992), à grande perda de peso ou de condição corporal no pós-parto (Butler \& Smith, 1989), ou ainda à grande exigência energética para alta produção de leite (Butler et al., 1981 e Hansen et al., 1992).

A alta taxa de aumento da produção de leite no início da lactação parece estar correlacionada negativamente com a taxa de concepção (Diskin, 1999). Provavelmente este efeito negativo é resultado da maior intensidade e da maior amplitude do balanço energético negativo das vacas de alta produção e não efeito da alta produção por si só. 
Vasconcelos et al. (1998) determinaram que vacas de alta produção e alto consumo de matéria seca (MS) possuem taxa de metabolização (“cleareance”) de progesterona (P4) maior em relação às vacas com menor consumo de matéria seca, justificando assim maior deficiência de P4, e conseqüentemente, possível menor concepção.

Após o parto, as vacas passam por um período de lento aumento na ingestão de alimentos, rápido aumento da produção de leite e uma intensa mobilização de reservas adiposas que afetam o desempenho reprodutivo (Butler \& Smith, 1989; Garnsworthy, 1988; Gearhart et al., 1990; Nebel \& McGilliard, 1993; Van Saun, 1991).

É estimado que $80 \%$ das vacas tenham balanço energético negativo no início da lactação, pois a energia necessária para produção de leite, e também para reprodução, não está disponível via dieta (Garnsworthy, 1988; Gearhart et al., 1990; Nebel \& McGilliard, 1993; Van Saun, 1991).

As vacas respondem individualmente a essa situação, tendo o desempenho sanitário e reprodutivo, particularmente a probabilidade da concepção, associado negativamente com a magnitude e severidade do balanço energético negativo do início da lactação (Butler \& Smith, 1989; Nebel \& McGilliard, 1993).

Devido à produção leiteira crescer com o aumento do número de lactações, e a alta produção de leite estar associada ao menor desempenho reprodutivo, é observado um efeito de redução no desempenho produtivo em função do aumento no número de lactações (Miettinem \& Setala, 1993).

Bagnato \& Oltenacu (1994) examinando dados de 1,2 milhões de lactações de 305 dias, coletados ao longo de 12 anos, notaram que as vacas de alta produção de leite tiveram uma taxa 0,15 menor ao $1^{\circ}$ serviço/concepção e 0,32 mais serviços por concepção que as vacas de baixa produção.

Avaliando estes dados podemos perceber o quanto é difícil determinar se o pior desempenho reprodutivo das vacas ocorre em função do aumento da produção de leite, ou verificar que ao longo das lactações os animais reduzem a capacidade reprodutiva devido a diversos fatores, tais como maior susceptibilidade a doenças (reprodutivas ou não) e maior sensibilidade ao estresse térmico. 


\subsection{Os componentes do leite associados à sanidade e reprodução}

A composição do leite de vaca varia em função de vários fatores, tais como raça, estação do ano, genética, estágio da lactação, sanidade e nutrição. As tendências econômicas atuais na comercialização do leite, provocando a demanda de certos produtos lácteos, afetam também a longo prazo a composição do leite.

A implementação de sistemas de pagamento está baseada em fazer com que os produtores orientem sua produção de acordo com as necessidades do mercado; por exemplo, se o mercado pagar incentivos para sólidos totais com bônus para proteína e gordura, os produtores irão começar a procurar tecnologias para aumentar a concentração destes componentes no leite.

\subsubsection{Gordura do leite}

A gordura é o componente de maior variabilidade no leite. De modo geral, a gordura pode variar de 2,2 a 4,0\%. Esta porcentagem é fortemente influenciada pela genética e fatores ambientais. Dentre os fatores ambientais, o manejo nutricional pode exercer uma influência muito importante na composição da gordura do leite.

De fato, se considerarmos a gordura, proteína e lactose como sendo os principais componentes do leite, a gordura é o componente de maior variação (Sutton, 1989). Provavelmente devido a esta variabilidade, foi o primeiro componente do leite a ser usado nos programas de pagamento do leite.

Uma considerável quantidade de pesquisas tem mostrado a relação entre a presença de forragens nas dietas e a concentração de gordura no leite de vacas. Assim sendo, a presença de forragens na dieta de vaca irá assegurar uma adequada concentração de gordura no leite (Sutton \& Morrant, 1989). Todavia, a determinação da proporção adequada de forragens nas dietas dependerá do tipo, da qualidade e da forma física dos diferentes alimentos que são fontes de fibra. 
As principais fontes de fibra na dieta são normalmente as forragens e, mesmo que seja possível o uso de outras fontes de fibra não oriundas das forragens, tem sido estabelecido como regra geral que uma dieta de gado leiteiro não deveria conter menos que $75 \%$ de fibra detergente neutra vinda das forragens. A forma física das forragens em dietas de vacas também deveria ser considerada a fim de maximizar a produção de gordura no leite (Sutton \& Morrant, 1989).

Quando as forragens são excessivamente picadas, com menos que $0,5 \mathrm{~cm}$, a efetividade da forragem em manter o bom estado do rúmen é diminuída e isto pode levar à acidose subclínica, que por sua vez, resultará numa produção diminuída de ácido acético (Emery, 1991). O acetato é o precursor da gordura do leite e qualquer diminuição de sua produção no rúmen resultará em concentrações sub-ótimas de gordura no leite (Sutton, 1989).

Durante o início da lactação, as vacas leiteiras alcançam sua máxima produção e normalmente entram em balanço energético negativo, já que não são capazes de consumir nutrientes suficientes para satisfazer as necessidades de sua alta produção de leite. Nesta fase, é necessário maximizar o consumo de nutrientes para permitir a máxima expressão do potencial genético dos animais. Ainda neste período, a adição de concentrados deve ser aumentada ao máximo, tendo cuidado para que não haja riscos de ocorrência de acidose ruminal.

Em geral, deve ser considerado que, quando as dietas contêm mais de $50 \%$ de concentrados (MS), há maiores riscos de redução no conteúdo de gordura no leite e de ocorrência de problemas na manutenção do equilíbrio ruminal. Nestas circunstâncias, os nutricionistas devem tomar cuidado e monitorar de perto o desempenho de cada formulação.

A proporção correta de FDN irá assegurar uma proporção correta de fibra na dieta; irá ainda manter a saúde do rúmen e garantir uma adequada proporção de ácidos graxos lipogênicos (acetato e butirato) e glucogênicos (propionato).

Entretanto, a forma física da fonte de fibra deve ser cuidadosamente avaliada, a fim de estimar a efetividade no conteúdo de FDN. A efetividade da FDN é 
mensurada na habilidade em manter a concentração de gordura do leite e na capacidade de estimular a ruminação (Linn, 1991).

Uma outra maneira de amenizar os efeitos da dieta sobre a diminuição da gordura do leite é o fornecimento mais freqüente de alimentos (Sutton \& Morrant, 1989). Com o oferecimento freqüente da dieta, o ambiente ruminal é mantido mais estável, com menores variações de $\mathrm{pH}$ e a manutenção dos microrganismos celulolíticos produtores de acetato.

\subsubsection{Proteína do leite}

O nitrogênio ou a proteína bruta do leite é composto pela caseína, proteínas do soro e frações de nitrogênio não protéico (NNP). No leite de vacas a proteína verdadeira constitui 95,1\% do nitrogênio total, sendo que a maior parte deste NNP é uréia. A caseína constitui 88\% do nitrogênio total ou 82\% da proteína verdadeira.

Caseína e gordura são os principais determinantes na produção de queijos, enquanto que as proteínas do soro, lactose e uréia são utilizadas em menor extensão no processamento do leite. Por causa da importância da concentração da proteína no leite, há uma tendência mundial em efetuar o pagamento do leite de acordo com a presença dela no conteúdo do leite. Entretanto, devido à importância da porcentagem de proteína verdadeira no leite usado para o processamento, há uma tendência em mensurar e pagar pela proteína verdadeira, ao invés da proteína total. Este fato se torna especialmente relevante se considerarmos que certas práticas alimentares podem causar variações consideráveis no conteúdo de NNP no leite (Sutton, 1989).

O aumento dos níveis de proteína na dieta acima das necessidades dos animais aumenta a proteína do leite, primariamente pela elevação da fração de NNP. Em termos gerais, aumentando a proteína bruta da dieta de 14 para 20\% (na matéria seca), verificamos um aumento na produção de leite pela elevação da digestibilidade, consumo alimentar e proteína para síntese do leite. O aumento na proteína do leite é somente marginal e muito deste aumento em proteína pode ser devido à uréia (Oldham, 1984). 
A amônia ruminal, a uréia do sangue, do plasma e do leite estão altamente correlacionadas. O balanço da dieta, no que tange a proporção de proteína degradável e não degradável no rúmen, tem uma relação próxima com a quantidade de uréia circulando no sangue e, conseqüentemente, na quantidade de uréia que entra no leite (Jonker et al., 1999).

Por outro lado, o fornecimento de níveis sub-ótimos de proteína na alimentação diminui a produção de leite mais do que a porcentagem de proteína no leite. Em geral poderia ser dito que as tentativas para modificar a porcentagem de proteína no leite não têm produzido evidências claras, a ponto de se recomendar práticas de manejo dirigidas a aumentar a proteína do leite acima dos níveis atuais.

\subsubsection{Nitrogênio uréico do leite (MUN)}

Os estudos sobre o nitrogênio uréico no leite (MUN), têm apresentado inúmeras controvérsias sobre sua utilidade como indicador do balanço protéico do animal e em conseqüência disto, do desempenho reprodutivo das vacas (Jonker et al., 1999).

O efeito do elevado consumo de proteína bruta sobre o desempenho reprodutivo de vacas em lactação é um assunto controverso, que pode ou não ocasionar efeitos indesejáveis sobre o intervalo entre cios, dias da $1^{\mathrm{a}}$ inseminação artificial, taxa de concepção, sobrevivência embrionária e outros (Fergunson et al., 1988 e Howard et al., 1987).

Revisando a literatura, Ferguson \& Chalupa (1989) demonstraram que o excesso de proteína degradável, em relação às exigências do animal, diminuiu a taxa de concepção. Além disso, ao estudarem os efeitos do excesso de proteína não degradável, também em relação às exigências do animal, demonstraram que a diminuição da taxa de concepção era ainda maior. Os autores postularam também que a porcentagem de proteína bruta na dieta é um fraco indicador da adequação da nutrição protéica de vacas, explicando que outros fatores, como energia da dieta e nível de produção da vaca, 
poderiam estar envolvidos na determinação das concentrações de uréia plasmática (PUN), uréia sangüínea (BUN) e uréia no leite (MUN).

A uréia é um produto de excreção do metabolismo do nitrogênio e sua determinação em amostras de soro sangüíneo, junto com a albumina, fornecem informação sobre a atividade metabólica protéica do animal. A concentração sangüínea de uréia (BUN) está em relação direta com o aporte protéico da dieta, bem com a relação energia: proteína (Oltner et al., 1985 e Kohn, 2000).

A uréia sangüínea, por apresentar baixo peso molecular, atravessa o epitélio alveolar da glândula mamária difundindo-se no leite, existindo uma alta correlação entre as concentrações de BUN e a concentração de uréia no leite (MUN) de uma vaca ( $r=0,904 ; p<0,01)$ (Roseler et al., 1993).

A quantidade de uréia tanto no sangue como no leite depende da relação energia: proteína, sendo que um aporte deficiente de proteínas está associado com valores diminuídos de uréia, enquanto que valores elevados de uréia indicam um aporte excessivo de proteínas (degradáveis e solúveis) no rúmen, ou estão relacionados com um aporte deficitário de energia (Kohn, 2000 e Jonker et al., 1999).

Com o objetivo de definir a qual destas duas últimas causas corresponde o aumento da uréia é útil determinar, junto com o MUN, a concentração de proteínas no leite, para uma interpretação em conjunto.

O conteúdo de proteínas do leite é dependente direto do aporte de energia da dieta. Um aporte deficiente de energia na dieta, leva à diminuição no conteúdo de proteínas no leite. Por outra parte, um excesso, em relação à energia, de proteínas degradáveis e solúveis no rúmen, leva a uma excessiva formação e absorção de amônia ruminal, com incremento de concentração de uréia no leite (Kohn, 2000).

Kaim et al. (1983), Bruckental et al. (1989), Canfield et al. (1990) e Larson et al. (1997) demonstraram uma diminuição significativa da taxa de concepção de grupos de animais que apresentaram concentrações de BUN iguais a 17, 32, 19 e 17 $\mathrm{mg} / \mathrm{dL}$, respectivamente para cada um dos estudos. 
Entretanto, Rajala-Schultz et al. (2001) sugeriram que os níveis de MUN adversamente associados com fertilidade podem ser inferiores aos reportados na literatura $(15,4 \mathrm{mg} / \mathrm{dL})$.

De forma contrária, Folman et al. (1981), Howard et al. (1987) e Carroll et al. (1988) não encontraram prejuízo na taxa de concepção mesmo quando os níveis de BUN chegaram a 15, 26 e 24 mg/dL, respectivamente. Melendez et al. (2000) ao estudar as concentrações de MUN de um rebanho da Flórida constatou que vacas com valores de MUN superiores a 16 mg/dL, cobertas durante os meses de verão, possuem um risco maior de não concepção à $1^{\text {a }}$ cobertura, quando comparadas a vacas com baixo MUN inseminadas nos meses de inverno, indicando que o MUN somente teve efeito sobre a não concepção quando associado à estação do ano e sendo assim, indicou a dificuldade de avaliar fatores como estação do ano e MUN isoladamente.

Os resultados do estudo de Godden et al. (2001) sugerem que um bom desempenho reprodutivo pode ser atingido mesmo em uma grande amplitude de concentrações de MUN.

Alguns autores (Bruckental et al., 1989 e Kaim et al., 1983) afirmam que as vacas multíparas são mais afetadas por desequilíbrios protéicos, embora Carroll et al. (1988) afirmem que as vacas primíparas sejam as mais suscetíveis.

Diversas hipóteses foram propostas para explicar os efeitos do desequilíbrio protéico sobre o desempenho reprodutivo de vacas leiteiras (Staples, 1990). Estas hipóteses podem ser classificadas em dois grandes grupos: os efeitos diretos e os efeitos indiretos.

Quanto aos efeitos diretos, as altas concentrações de uréia, amônia ou de outro composto nitrogenado desconhecido agiriam sobre o eixo hipotálamo-hipofisárioovariano, sobre os gametas, sobre os embriões em desenvolvimento ou sobre o sistema imune, prejudicando o processo de fertilização, o desenvolvimento embrionário ou a implantação do embrião (Butler et al., 1995 e Staples, 1990).

Existe ainda a teoria de que o excesso de amônia transformada em uréia pode interferir no metabolismo intermediário e influir nas concentrações de glicose, 
lactato e ácidos graxos livres no sangue e na funcionalidade do corpo lúteo, além de ocasionar uma diminuição da capacidade imunogênica dos macrófagos (Staples, 1990).

Os efeitos indiretos do desequilíbrio protéico seriam efetuados através do aprofundamento do balanço energético negativo, seja através do aumento da produção de leite, promovida pela maior disponibilidade de proteína, seja pelo maior gasto no processo da detoxificação da amônia (Jonker et al., 1999 e Staples, 1990).

\subsection{Efeitos do estresse térmico sobre reprodução e produção}

Segundo Yousef (1985), o estresse térmico pode ser definido como a somatória de forças externas ao animal homeotérmico, que atuam de forma a alterar a temperatura do estado de repouso, sendo este tipo de estresse capaz de desorganizar a fisiologia e o desempenho reprodutivo dos animais.

Na termoneutralidade, a vaca pode manter a homeostase sem o gasto excessivo de energia para termoregulação, estando esta energia, conseqüentemente, disponível para manter condições ótimas de saúde e desempenho (Yousef, 1985).

Quando o calor aumenta, o animal precisa eliminar energia direta para diminuir o calor excessivo e tentar manter o equilíbrio térmico interno. Todavia, nem sempre este mecanismo é suficiente. Por conseguinte, a temperatura corporal aumenta, afetando várias funções fisiológicas do corpo (Wolfenson et al., 2000).

O aumento da temperatura corporal causada pelo estresse térmico provoca conseqüências adversas diretamente na função celular, podendo, por exemplo, reduzir o percentual de embriões capazes de concluírem seu desenvolvimento (Ealy et al., 1995).

Além disso, as mudanças e adaptações fisiológicas pelas quais os animais passam durante o estresse térmico podem comprometer sistemas importantes em termos fisiológicos. Exemplo disto é a redistribuição do fluxo sangüíneo das vísceras para a periferia em períodos de estresse térmico. Apesar de aumentar a dissipação de calor do 
corpo no ambiente, essa resposta também ocasiona a diminuição na perfusão vascular da placenta (Alexander et al., 1987) e atraso no crescimento do feto (Collier et al., 1982).

A produção de leite, o consumo de alimentos e a atividade física são reduzidas durante os períodos de estresse térmico (Fuquay, 1981); ao mesmo tempo, a habilidade reprodutiva é afetada (Francos \& Macer, 1983 e Gwazdauskas, 1985). Está constatado que perdas produtivas e reprodutivas associadas com o EC são economicamente importantes (Igono et al., 1987).

Vários autores afirmam que o problema do estresse térmico tenderá a aumentar muito no futuro. A intensidade do estresse térmico poderá primeiramente aumentar em função do aquecimento global contínuo (Hulme, 1997). Em segundo lugar, a população mundial está crescendo de forma mais rápida nas áreas tropicais e subtropicais do que nas temperadas (Roush, 1994), assim é razoável supor que um número maior de animais de produção seja criado nessas regiões para suprir a demanda de consumo. E, por fim, as alterações na genética e fisiologia dos animais para aumento de produção os estão tornando menos capazes de regular a temperatura corporal e menos adaptados aos ambientes quentes.

\subsubsection{Efeitos do estresse térmico sobre a reprodução}

Os primeiros relatos da diminuição na fertilidade de vacas durante o verão são de 1940 (Erb et al., 1940) e 1941 (Seath \& Staples, 1941).

Parições durante as estações quentes do ano suprimiram a reprodução de vacas leiteiras no Arizona (Ray et al., 1992), Flórida (Silva et al., 1992), Kentucky (Olds et al., 1979), Mississipi (Moore et al., 1992) e Carolina do Norte (Farin et al., 1994; Faust et al., 1988; Seykora \& McDaniel, 1983). Nestes estudos, o estresse térmico reduziu drasticamente as taxas de concepção nas vacas leiteiras. Vacas paridas no verão tendem a ter menores taxas de concepção, sendo esta situação ainda mais agravada

quando as vacas produzem mais leite (Faust et al., 1988). Na Flórida, as taxas de concepção declinaram de 40 a 50\% durante meses frescos para menos de 10\% durante os meses quentes do ano (Badinga et al., 1985). 
Nos trabalhos de Farin et al. (1994), Faust et al. (1988), Seykora \& McDaniel (1983) e Silva et al. (1992), taxas menores de concepção foram relacionadas com o aumento de dias à $1^{\text {a }}$ cobertura, e a menor concepção na inseminação artificial, quando os animais pariram ou foram cobertos durante o verão.

Foram observadas taxas de concepção significativamente mais baixas em vacas cuja temperatura corporal era superior à normal no momento da inseminação, por causa da baixa fertilização e de uma alta incidência de mortes embrionárias (Fuquay, 1981). Uma maior mortalidade embrionária devido ao estresse térmico também foi observada nos estudos de Ealy et al. (1993) e Pursley et al. (1997).

A viabilidade dos óvulos e dos espermatozóides também foi reduzida significativamente quando as temperaturas do corpo apresentaram-se mais altas que o fisiológico, resultando em redução da fertilidade (Chenoweth \& Larsen, 1992). A libido dos touros, quando do uso de monta natural, também foi reduzida (Chenoweth \& Larsen, 1992).

Constatou-se que temperaturas altas afetam o desenvolvimento de embriões jovens, os quais são muito mais vulneráveis nos primeiros dias de vida, reduzindo-se drasticamente as taxas de sobrevida (Ealy et al., 1993; Fallon, 1962; Nebel \& Jobst, 1998; Stott \& Williams, 1969).

O estresse térmico afeta fortemente a expressão do cio pelas vacas, (Abilay et al., 1975 e Gangwar et al., 1965), diminuindo a intensidade e duração dos cios; desta forma é difícil a identificação dos animais para execução da cobertura, ocasionando um efeito negativo na incidência e na intensidade de montas (Nebel \& Jobst, 1998 e Thatcher \& Collier, 1986). Já no caso das novilhas, as taxas de concepção não se alteram tanto em função da estação do ano (Thatcher \& Colier, 1986 e Francos \& Macer, 1983).

Quando Thatcher \& Colier (1986) analisaram os resultados de 6555 inseminações realizadas em um rebanho, no período de três anos, eles encontraram uma taxa de concepção mais alta para as novilhas em relação às vacas em lactação, ao longo do ano. Esta diferença foi maior durante os meses de verão na Flórida (junho, julho, e agosto). Semelhantemente, a taxa de concepção para novilhas, em Israel, ficou inalterada 
durante o verão, enquanto que a fertilidade das vacas era reduzida (Francos \& Macer, 1983).

Uma possível explicação é que a produção metabólica de calor pelas vacas em lactação ocasione hipertermia no verão. Já as novilhas, com menor produção de calor interno, podem não se tornar hipertérmicas a temperaturas ambientais equivalentes. As respostas reprodutivas ao estresse térmico deveriam ser semelhantes, tanto para vacas como para novilhas, se a hipertermia produzida fosse equivalente. Devido a este fato, pode-se considerar que a lactação modifica a resposta do animal ao estresse térmico (Wilson et al., 1998a) e também que as novilhas podem responder fisiologicamente melhor ao estresse térmico, tendo o desempenho reprodutivo menos afetado que as vacas (Thatcher \& Colier, 1986).

Ainda avaliando o efeito do estresse térmico sobre as novilhas, Wilson et al. (1998b) determinaram que o estresse térmico inibiu o desenvolvimento do folículo dominante durante o período pré ovulatório. Constataram ainda que, em conseqüência do estresse térmico, as concentrações séricas de estradiol foram reduzidas, o declínio de progesterona na fase luteal foi atrasado e a porcentagem de novilhas com ciclos estrais com três ondas foliculares foi aumentado.

Durante a hipertermia induzida pelo estresse térmico, as novilhas e vacas em lactação (Wilson et al., 1998a e 1998b) sofreram mudanças semelhantes na função ovariana. Embora os mecanismos sejam somente entendidos parcialmente, este experimento demonstrou que uma resposta aguda ao estresse térmico influencia similarmente a função ovariana em novilhas e vacas.

Apesar dos efeitos do estresse térmico serem muito bem conhecidos, os mecanismos fisiológicos que conduzem à infertilidade de verão são apenas parcialmente entendidos; como conseqüência, muitos estudos publicados trazem resultados inconsistentes.

Algumas das perdas reprodutivas por estresse térmico (EC), são associadas com a diminuída expressão do estro (Her et al., 1988; Madan \&. Johnson,. 1973 e Younas et al., 1993). Uma hipótese explicativa para este acontecimento é que o EC inibe o desenvolvimento folícular ovariano e reduz as concentrações de estradiol 
(Ealy et al., 1993). Estudos comparativos de concentrações de estradiol no sangue de vacas, sob estresse térmico e vacas controle, geraram resultados inconsistentes (Gwazdauskas et al., 1985, Roman-Ponce, et al., 1981 e Rosenberg et al., 1982).

Outros estudos (Badinga et al., 1993 e Wolfenson, et al., 1995) empregaram ultra-sonografia para examinar o crescimento folícular em vacas sob EC. Badinga et al. (1993) concluíram que o EC agudo reduziu o tamanho do folículo dominante no $8^{\circ}$ dia do ciclo estral e a duração da primeira onda. Reduções no estradiol do folículo foram induzidas pelo estresse térmico, quando crônico, ocorrendo apenas no final do verão (Badinga et al. 1993). Wolfenson et al. (1995) injetaram uma dose luteolítica de $\mathrm{PGF}_{2} \alpha$ no $12^{\circ}$ ou $14^{\circ}$ dia do ciclo estral, obtendo conclusões semelhantes (redução do folículo dominante e estradiol em vacas com EC). A ultra-sonografia precedente a estes estudos sugere a redução da função folícular em vacas com EC, durante a primeira onda folícular ou quando a luteolise é induzida com $\mathrm{PGF}_{2} \alpha$

Em outro estudo de Wilson et al., (1998a), o estresse térmico inibiu o crescimento folícular e a dominância durante o período pré-ovulatório. A função ovariana anormal em vacas submetidas a estresse térmico manifestou-se pela diminuição da elevação de estradiol no proestro, menor tamanho da segunda onda do folículo dominante, maior número de ondas foliculares por ciclo de estral e fases luteais mais longas. A explicação do autor é que a diminuição no estradiol sérico pode ter interrompido os mecanismos luteolíticos naturais e resultado em fases luteais mais longas com ondas foliculares repetidas.

Gwazdauskas et al. (1975), procurando determinar as variáveis climáticas mais importantes na determinação da taxa de concepção, constataram a temperatura máxima no dia da inseminação e a ocorrência de chuva no dia de inseminação. Ingraham et al. (1974) afirmam porém que a média do índice de temperatura e umidade, dois dias antes da inseminação, teve uma relação mais alta que a mesma variável no dia de inseminação e no dia após a inseminação.

Diversas estratégias de manejo foram testadas para reduzir os efeitos do estresse térmico sobre a reprodução, resultando que a alteração do ambiente da vaca pelo 
uso de sombras, ventiladores, ou resfriadores evaporativos é a mais utilizada (Bucklin et al, 1991).

Esta técnica, contudo, nem sempre elimina todos os problemas associados com estresse térmico. Por exemplo, em rebanhos leiteiros do Arizona, o intervalo entre o parto e a concepção, durante o verão, permaneceu de 24 a 67 dias mais longo do que o intervalo observado durante inverno, embora, durante todo o verão, as vacas tenham sido mantidas em instalações com resfriadores evaporativos (King et al., 1988). Já RomanPonce et al., (1977), mantendo vacas em ambiente sombreado, conseguiram aumento na produção de leite e melhores taxas de concepção em relação às vacas mantidas em ambiente sem sombra.

Armstrong (1994) considera que as medidas de manejo sejam efetivas, reduzindo o efeito de estresse térmico somente até um certo grau; considera que tais medidas não são capazes de eliminar por completo o efeito deletério do estresse térmico sobre a reprodução.

Devido a afirmações como esta, prosseguem as buscas por estratégias reprodutivas adicionais, necessárias para combater os efeitos adversos do estresse térmico.

Uma das recentes estratégias encontradas consiste no uso de inseminação artificial em tempo fixo (IATF). Ela é baseada em protocolos que envolvem injeções previamente programadas de $\mathrm{GnRH}$ (ou seus agonistas) e $\mathrm{PGF}_{2} \alpha$, para provocar a sincronização de ovulação (Burke et al., 1996; Pursley et al., 1995; 1997a, 1997b e 1998 e Schmitt et al., 1996). O uso da IATF oferece vantagens por induzir a atividade reprodutiva logo no início da lactação, reduzindo a necessidade da detecção de estro, e assim sendo, mostra-se particularmente efetiva durante períodos de estresse térmico.

Outra estratégia possível para aumentar a função reprodutiva durante o estresse térmico consiste na suplementação alimentar das vacas com antioxidantes. Esta sugestão está baseada na evidência de que os efeitos da elevação das temperaturas durante o desenvolvimento de embriões cultivados se relaciona com a produção de radicais livres (Aréchiga et al., 1995). Aréchiga et al., (1995) determinou que a exposição de embriões de rato ao choque de calor diminui as concentrações 
intracelulares do antioxidante glutationa, e que quando houve a inibição da síntese de glutationa aumentou-se a sensibilidade ao choque térmico.

Em outros estudos, a adição de vários antioxidantes no meio de cultura provocou a diminuição dos efeitos da elevação de temperatura em embriões de bovinos e ratos (Aréchiga et al., 1994 e 1995 e Ealy et al., 1993 e 1994). Administrando injeções de vitamina E no momento da inseminação artificial não se obteve sucesso no aumento das taxas de concepção em vacas estressadas pelo calor; a explicação do autor (Ealy et al., 1994) para o insucesso é que o antioxidante não foi administrado por um número suficiente de dias para proteger o embrião da ação do estresse térmico.

A manipulação de certos ingredientes de dieta é uma outra estratégia benéfica: diminuir os níveis de fibra, respeitando-se os limites adequados para manter a função ruminal adequada, pode ser uma medida efetiva para o alivio parcial do estresse térmico (Cummins, 1989). Também é defendida como um dos possíveis meios de reduzir estresse térmico a prática de formular dietas com gordura suplementar, devido ao alto conteúdo de energia e baixo incremento de calor dos lipídios em relação a outros nutrientes (Beede \& Collier, 1986 e Morrison, 1983).

\subsubsection{Efeitos do estresse térmico sobre a produção leiteira}

A seleção genética de vacas com base na produtividade de leite reduziu a capacidade termorreguladora diante do estresse térmico (Berman et al., 1985) e ampliou a diminuição sazonal da fertilidade (Al-Katanani et al., 1998 e 1999). Acrescentando-se

a isto o emprego de novas tecnologias, tais como o uso de promotores de lactação (somatotropina - bST), o estresse térmico pode ser agravado, pelo fato de aumentar a produção de leite, a taxa metabólica e a produção de calor corporal (West et al, 1991; Hansen et al., 1992 e Cole \& Hansen, 1993).

Muito esforço foi investido para se encontrar raças ou cruzamentos, que sejam tolerantes ao calor e muito produtivos. Contudo, até hoje, este esforço não teve o êxito esperado pelos produtores de leite (McDowell et al., 1996). 
Entretanto, Ravagnolo \& Misztal (2000) e Ravagnolo et al. (2000) afirmam que há variabilidade genética dentro da raça Holandesa suficiente para permitir uma seleção voltada para a tolerância ao calor, para produção de leite, gordura e de proteína. Estes autores definiram uma habilidade de produção regular, que é a habilidade genética para produzir leite na ausência de tolerância de calor, e um efeito genético para tolerância ao calor, que consiste na habilidade genética para evitar a redução do rendimento de leite quando submetida à exposição ao estresse térmico. Desta maneira afirmam ser possível selecionar simultaneamente animais com ambas as características. Isto também é possível para as características reprodutivas, que parecem mesmo ser mais susceptíveis ao estresse térmico do que a produção (Hansen, 2000).

Gasparino (1996) em seu estudo encontrou diferenças na produção de leite em função da época do parto, assegurando que ela foi influenciada, direta e/ou indiretamente, pela época do parto.

Devido às diferenças de temperatura e umidade entre as estações do ano, o impacto do ambiente sobre o animal poderá ser maior ou menor (Hansen et al., 1992). É evidente o efeito que as estações do ano podem exercer sobre a qualidade e a quantidade de volumosos produzidos, e o efeito destes sobre o estado nutricional do animal. Todavia, os efeitos e a intensidade do estresse térmico sobre a produção leiteira em função da época do parto dependem da tecnologia utilizada na atividade.

O efeito será maior quando for maior a dependência às pastagens e ao ambiente (por exemplo, o sombreamento), sendo tal efeito reduzido se ocorrer durante o ano inteiro o fornecimento de alimentos com alta qualidade, sombreamento e adoção de técnica de controle de temperatura ambiental (Pires, 1984 e Hansen, 2003).

No Brasil e no exterior, a estação de parição tem sido mencionada por muitos autores como um importante fator que afeta a produção de leite, seja de vacas Holandesas ou mestiças (Almeida et al., 1997; Balieiro et al., 1997; Costa et al., 1982; Gasparino, 1996; Matos et al., 1996; Mota et al., 1996; Queiroz et al., 1987; Ribas et al., 1996). 


\subsection{Sanidade (Desordens sanitárias do periparto)}

Apesar das doenças do periparto costumeiramente não afetarem um grande número de animais do rebanho, seus efeitos na vaca afetada podem ser grandes, causando inúmeras perdas à atividade. O parto é um evento crucial na vida da vaca, estando a maioria das doenças e custos veterinários, associados mais ao pós-parto do que a qualquer outro período do ciclo produtivo.

As desordens do periparto não devem ser analisadas apenas isoladamente, pois existe forte relação entre elas. Estudos citam, por exemplo, a hipocalcemia como fator de risco para outras desordens: distocias, retenção de placenta, cetose, prolapso de útero, metrites e deslocamento de abomaso. Várias destas doenças ocorrem como complexos de desordens, nos quais uma doença pode predispor à outra (Grohn et al., 1990; Risco, 1992; Correa et al., 1993 e Emanuelson \& Oltenacu, 1998). Os complexos de desordens podem aumentar o risco de infecções uterinas no pós-parto, afetando a fertilidade das vacas por causar atrasos na involução uterina e predispor a alterações degenerativas na função do ovário (Bosu \& Peter, 1987).

Além de serem fatores que afetam diretamente os órgãos reprodutivos, muitas destas doenças reduzem o consumo de alimentos, prejudicando o equilíbrio energético; causam a mobilização de reservas corporais dos nutrientes, afetando a produção e a composição do leite.

As doenças podem afetar a eficiência produtiva por reduzir a produção de leite, o desempenho reprodutivo ou a expectativa de vida da vaca leiteira (Dohoo et al., 1983). Contudo, o efeito da ocorrência de doenças no periparto sobre a produção do leite não é fácil de ser avaliado, pois depende de vários fatores, tais como a habilidade em reconhecer os sintomas da doença, a rapidez na execução do tratamento, bem como do manejo geral do rebanho (Ostergaard et al., 2000). Além disso, diferentes critérios de diagnóstico podem afetar as estimativas, ou mesmo invalidar o estudo.

Outra constatação é que vacas com altas produções são mais susceptíveis a doenças e que durante os períodos quentes do ano o número de ocorrências aumenta 
(Dohoo \& Martin, 1984a; Dohoo et al., 1984; Markusfeld, 1990; Grohn, 1990 e Sargeant et al., 1998).

Assim sendo, fica difícil determinar se o efeito sobre a reprodução é devido às grandes produções de leite, ao estresse térmico ou somente às doenças ou a suas causas isoladamente.

\subsubsection{Hipocalcemia}

A paresia puerperal (também denominada hipocalcemia ou febre de leite) é uma doença metabólica comum em animais leiteiros, que ocorre no parto ou nas proximidades deste, especialmente em vacas com grande produção de leite.

A doença é caracterizada por um rápido declínio nas concentrações de Cálcio (Ca) do plasma, resultante da mobilização relativamente grande de Ca para formação do leite (principalmente o colostro); também se caracteriza por causar fraqueza muscular.

Uma vaca que produz, por exemplo, 10 litros de colostro, perde aproximadamente 23 g de Ca em uma única ordenha. Esta quantia é aproximadamente nove vezes maior do que o Ca presente em todo o pool de plasma da vaca (Horst et al., 1997).

O cálcio perdido deve ser reposto pelo aumento da absorção de Ca intestinal, por aumento da reabsorção de Ca dos ossos, ou por ambos os processos.

Durante o período seco, quando as exigências de Ca são mínimas (10 a 12 g Ca/dia), estes mecanismos estão relativamente inativos (Ramberg et al., 1984). Por ocasião do parto, porém, a vaca precisa suprir a necessidade de $30 \mathrm{~g}$ de $\mathrm{Ca} / \mathrm{dia}$. Como conseqüência desta súbita exigência de $\mathrm{Ca}$, todas as vacas experimentam algum grau de hipocalcemia durante o primeiro dia pós-parto, até que o intestino e os ossos se adaptem à demanda de Ca resultante da lactação (Curtis et al., 1984).

Os sinais clínicos variam de tremores musculares, nos estágios iniciais, até paralisia flácida, coma e morte nos estágios avançados. Os tratamentos de Ca intravenosos (normalmente 8 a $10 \mathrm{~g}$ de $\mathrm{Ca}$ ) produzem muito bons resultados e são 
capazes de manter a vaca viva até que os intestinos e ossos se adaptem aos mecanismos que transportam o Ca. Aproximadamente de 60 a 70\% das vacas morrem dentro de um ou dois dias após a manifestação dos sintomas, quando não tratadas (Hibbs, 1950).

A importância da hipocalcemia para a atividade leiteira não é bem quantificada devido à pequena incidência de casos; além disso, o tratamento é eficaz e facilmente realizado. Os valores de incidência reportados em estudos variam de 1,2\% a 14, 1\%, demonstrando a grande maioria dos estudos incidências inferiores a 7\%.

A incidência de hipocalcemia aumenta em função da idade, sendo esta relação explicada pelo fato de que a produção de leite aumenta, enquanto que a disponibilidade de cálcio diminui com a idade (Oetzel et al., 1988 e Oetzel, 1993).

A hipocalcemia é uma doença economicamente importante, podendo reduzir a vida produtiva de uma vaca em 3 ou 4 anos (Payne, 1968). O custo médio por caso de febre de leite foi calculado recentemente em US\$ 334 (Guard, 1996). Este valor baseia-se no custo direto, associado com o tratamento dos casos clínicos e com as perdas de produção calculadas. Vacas com febre de leite são mais suscetíveis a problemas secundários que aumentam significativamente o custo de produção.

Animais que desenvolvem o quadro de hipocalcemia possuem níveis elevados de cortisol no plasma em comparação com animais que não a desenvolveram, acentuando a já deprimida capacidade imunológica da vaca no pós-parto (Curtis et al., 1984). Curtis et. al (1983) demonstrou que vacas se recuperando da febre de leite têm oito vezes maior chance de sofrerem de cetose e mastite (especialmente mastite por coliforme) do que vacas que nunca tiveram febre de leite.

A incidência de distocia, retenção de placenta, deslocamento de abomaso (síndrome da vaca caída) e prolapso uterino também são grandemente aumentadas como resultado de febre de leite (Horst et al., 1997). 


\subsubsection{Retenção de placenta}

A retenção das membranas fetais (RMF), mais comumente denominada retenção de placenta (RP), constitui uma desordem freqüente no pós-parto, podendo ser definida patologicamente como a retenção das membranas fetais por um período maior que 12 a 24 horas após a parição (dependendo dos autores). Em condições normais, a placenta é expelida dentro do período de 3 a 12 h após o parto (Roberts, 1986).

Trabalhos relatam que a incidência de retenção de placenta varia de 3 a 39\% sendo estes dados muito influenciados pela definição de RP utilizada (Grunert, 1986, Laven \& Peters, 1996). Em um grande estudo americano, realizado pelo USDA (USDA, 1996), a incidência de RP obtida para vacas leiteiras foi de 7,8 \%.

A retenção de placenta ocasiona significativas perdas econômicas, pois muitas vacas com RP desenvolvem metrite e podem sofrer de infertilidade (Coleman et al., 1985), sendo que a RP também pode provocar a diminuição da produção de leite (Lucey et al., 1986).

O número de casos e a incidência podem aumentar com partos anormais (distocias, gêmeos, cesarianas, induzidos, abortos e prematuros), com rebanhos infectados por brucelose, leptospirose, vibriose, listeriose, rinotraqueite infecciosa bovina e outros organismos infecciosos, com problemas de manejo, com deficiências nutricionais (vitaminas A e E, minerais como selênio, cobre e iodo), com doenças metabólicas e mastites agudas na parição.

Permanecem obscuros tanto os mecanismos de expulsão da placenta como as causas da RP. Vários fatores como idade, espécie, hereditariedade, ambiente, hormônios e nutrição foram sugeridos como causas da RP (Hurley \& Doane, 1989).

Gunnink (1984) propôs uma teoria instigante, afirmando que no parto, quando cessa o suprimento de sangue para a placenta, esta se torna um "corpo estranho" ao organismo. $\mathrm{O}$ autor sugeriu que o sistema imune materno reconhece o "corpo estranho" e "ataca" a placenta fetal, expelindo-a. Os dados, porém, são conflitantes e nenhum fator isolado, endócrino ou nutricional, é capaz de fornecer uma explicação satisfatória do porquê das vacas desenvolverem esta desordem. 
A retenção de placenta aumenta o risco de ocorrência de metrites, resultando em redução da fertilidade, aumento dos dias para concepção e aumento no risco de descarte, além de acarretar diminuição da produção de leite. São evidentes, portanto, as graves conseqüências econômicas. O custo estimado por caso, somando-se os custos de tratamento e perda de produção, foi de US\$ 285 (Guard, 1996).

No estudo realizado por Rajala \& Grohn (1998b) a retenção de placenta teve um efeito negativo significante sobre a produção de leite durante várias semanas após o parto. Lucey et al. (1986) determinaram que a retenção de placenta suprimiu a produção leite por aproximadamente quatro semanas depois do parto; Rowlands \& Lucey (1986) informaram que a retenção de placenta reduziu a produção de leite no pico de lactação, mantendo este efeito negativo por um período maior; eles calcularam uma redução de 7\% na produção aos 305 dias para as vacas com retenção placenta.

No estudo de Van Werven et al. (1992) as vacas mais velhas diminuíram a produção de leite em função do aumento na duração dos casos da retenção de placenta. Simerl et al. (1992) observaram que a produção de leite das vacas de primeira lactação foi reduzida devido à retenção de placenta. Deluyker et al. (1991) reportaram que vacas com RP tiveram produções médias menores durante os primeiros cinco dias após o parto.

Martin et al. (1986) não determinaram nenhum efeito da retenção das membranas fetais sobre a produção de leite ao longo dos 305 dias de lactação. A perda da tonicidade muscular do útero, comum durante quadros de retenção de placenta, é também um dos principais causadores do prolapso uterino (Risco et al., 1984).

Como a retenção de placenta possui múltiplas causas, torna-se difícil estabelecer sua origem; um efetivo sistema de coleta de dados pode ajudar na identificação dos fatores causais. 


\subsubsection{Cetose}

Cetose constitui uma desordem metabólica por vezes incluída na categoria de síndrome da vaca gorda, e seu nome tem origem nas características dos metabólitos presentes durante sua ocorrência. Trata-se de um problema metabólico associado ao suprimento inadequado de energia no início da lactação de vacas leiteiras de alta produção, caracterizado por queda na concentração de glicose e aumento excessivo de corpos cetônicos no sangue (Gustafsson et al., 1993). Este quadro é conhecido como acetonemia, podendo ocorrer na forma clínica ou subclínica (Lean et al., 1991 e 1992). Normalmente ocorre entre os 10 dias e 6 semanas após o parto; contudo, a maioria dos casos se concentra por volta de três semanas após o parto (Grummer, 1993).

Ocorre um grande aumento nas concentrações plasmáticas de corpos cetônicos, o acetoacetato e o $\beta$-hidroxibutirato. A maior concentração de corpos cetônicos é resultado do equilíbrio energético negativo causado pelo aumento das necessidades de nutrientes para a síntese de leite. A retirada da glicose da circulação sangüínea (hipoglicemia) para síntese da lactose do leite estimula indiretamente a mobilização de ácidos graxos do tecido adiposo e a subseqüente oxidação destes ácidos graxos no fígado. Estes ácidos graxos são metabolizados por vários tecidos, mas tendem a se acumular no fígado (como acetil-CoA), devido à reduzida habilidade da utilização destes pelo fígado. O excesso de acetil-CoA é convertido então em cetonas: acetoacetato, $\beta$-hidroxibutirato e acetona. Estes, por sua vez, podem ser metabolizados por vários tecidos, inclusive pelos músculos. Contudo quando a produção de corpos cetônicos ultrapassa a capacidade de uso pelos tecidos periféricos, há o acúmulo, desenvolvendo-se então o quadro clínico ou subclínico da cetose (Risco, 1992).

A sintomatologia clínica inclui a diminuição da produção leiteira, com sinais de hipofagia, perda rápida de peso, sinais de acometimento do sistema nervoso central, hálito cetótico característico (odor de acetona), hipoglicemia, hipoinsulinemia, 
altos níveis de ácidos graxos livres no sangue, letargia e por vezes morte (Guard, 1995 e Veenhuizen et al., 1991).

A incidência de cetose nos rebanhos é bastante variável; em rebanhos canadenses, Dohoo et al., (1984a e 1984b) encontraram incidência de 9,6\%; já Duffiled et al., (1998) encontraram $14,1 \%$ de animais acometidos.

Nos EUA, a incidência varia de 4 a 7\%, sendo mortal para 1\% e causando o descarte de $5 \%$ destes animais. A perda de produção calculada é de $200 \mathrm{~kg}$ por lactação. Estas perdas podem ser maiores quando somadas às perdas causadas pela cetose sub-clínica (Schlatter, 1997).

No Brasil poucas pesquisas fornecem dados sobre a incidência em rebanhos leiteiros. Lago (1997) encontrou 13,56\% (sub-clínica) e 0,84\% (clínica); Fonseca (1997) observou o acometimento de 21,7\% dos animais (clínica). Contudo nos estudos nacionais citados o número de animais avaliados sempre foi pequeno (inferior a 100 observações).

As altas concentrações de corpos cetônicos no sangue foram relacionadas com a redução de fertilidade (Andersson, 1998; Andersson et al., 1991; Butler \& Smith, 1989; Emanuelson et al., 1993) e com o aumento no risco de ocorrência de infecções uterinas (Dohoo \& Martin, 1984a).

\subsubsection{Deslocamento de abomaso}

O deslocamento de abomaso (DA) é uma doença comum em vacas com altas produções de leite (Grymer, 1980; Robb et al., 1986 e Cameron et al., 1998). Ocorre com maior freqüência até oito semanas pós-parto. Causa perda econômica devido aos custos de tratamento, ao descarte prematuro, à perda de produção e à morte (Geishauser et al., 1997).

As teorias para explicar a sua ocorrência são variadas, indo desde a obesidade das vacas (vacas com ECC maior de 4,5) até a diminuição no consumo de forragens ou de fibra efetiva (Shaver, 1997). 
Trabalhos citam uma incidência entre $0,9 \%$ e 2,5\%, sendo variável segundo os sistemas de criação (confinado ou a pasto) e os regimes de alimentação (dietas completas, fornecimento separado de concentrado e volumoso, etc.).

As estimativas da incidência média anual de DA para esquerda (DAE) variam de 1,4 a 5,8\% (Correa et al., 1990; Curtis et al., 1985, Erb et al., 1984; Jordan \& Fourdraine, 1993; Markusfeld, 1987; Massey et al., 1993 e Pehrson \&. Shaver, 1992).

Phearson \& Shaver (1992) obtiveram uma taxa de incidência média para DAE de 5\% (0 a 21,7\%) pesquisando 71 rebanhos e um total de 5742 vacas. As taxas de incidência variaram de 1\% (0 a 3\%) em 34 rebanhos de baixa incidência (<3\% DAE) a 8,7\% (3,2\% a 21,7\%) em 37 rebanhos com alta incidência (> 3\% DAE).

Jordan \& Fourdraine (1993) encontraram uma taxa de incidência média para DAE de 3,3\% (0 a 14\%) pesquisando 61 rebanhos (com aproximadamente 244 vacas por rebanho) de alta produção (média 11.096 kg de leite por lactação).

Apesar das perdas financeiras serem grandes, variando de US\$ 256 a US\$ 406 por caso, no estudo realizado por Bartlett et al. (1986), que associou as despesas com o tratamento e as perdas de produção, ou de US\$ 100 a US\$ 200 por caso, no estudo de Eicker (1995), no qual também se constatou que 10\% das vacas diagnosticadas com DA são descartadas ou morrem precocemente, as pesquisas nesta área permanecem escassas e com resultados controversos.

Eicker (1995) observou ainda nesse estudo que as vacas tratadas que permaneceram no rebanho produziram $350 \mathrm{~kg}$ menos de leite no mês seguinte do que vacas sem DA, demonstrando claramente desta forma as perdas na produção provocadas por esta desordem metabólica.

Apesar de que o deslocamento de abomaso pode ocorrer tanto para direita como para esquerda, de oitenta a noventa por cento dos casos de deslocamento ocorrem para esquerda (Guard, 1990; Pehrson \&. Shaver, 1992 e Whitlock, 1969).

O deslocamento de abomaso (DA), quer seja para direita ou para esquerda, é considerado como uma doença multifatorial. Estudos epidemiológicos identificaram como fatores de risco potencial: a raça (Constable et al., 1992), o sexo do bezerro (Constable et al., 1992), a idade da vaca (Constable et al., 1992; Erb \& Grohn, 
1988 e Markusfeld, 1987), o tipo do parto: normal ou distócico (Constable et al., 1992 e Markusfeld, 1987), e a época do ano (Constable et al., 1992; Erb \& Grohn, 1988; Markusfeld, 1987 e Robb et al., 1986).

Também foi encontrada importante associação entre o DA e outras desordens do periparto: hipocalcemia (Curtis et al., 1983; Hull \& Wass, 1973; Martin,1972 e Massey et al., 1993), cetose (Curtis et al., 1985, Pehrson \& Shaver. 1992; Van Dijk et al., 1989) e metrites (Markusfeld, 1987).

Uma especulação surgiu sobre a associação entre desordens do metabolismo energético (fígado gordo e cetose) e a ocorrência de DA (Curtis et al., 1985, Erb \& Grohn, 1988 e Van Dijk et al., 1989). O balanço energético negativo é o fator desencadeante do desenvolvimento da cetose e fígado gordo, sendo que este desequilíbrio freqüentemente pode começar durante o período de pré-parto (Grummer, 1993).

Outra possível explicação está no fato de que vacas super condicionadas realmente apresentarem redução de apetite após o parto. Esta redução de apetite limita o consumo de forragem e diminui as contrações e o tônus da musculatura do rúmen. Com isto, o abomaso tem a possibilidade de movimentação (Geishauser et al., 1997). Dietas com reduzidas proporções de fibra também podem reduzir o tônus da musculatura ruminal e o enchimento ruminal (Shaver, 1997).

A nutrição tem impacto significativo na incidência de DA e talvez seja o fator causal mais controlável (Cameron et al., 1998). Medidas preventivas recomendadas incluem evitar o consumo excessivo de concentrados durante o período seco, alimentando-se os animais com fibra longa antes e após o parto e manter o controle da condição corporal. 


\subsubsection{Metrites}

As metrites e endometrites são inflamações do útero. Metrites envolvem o endométrio, os tecidos glandulares e as camadas musculares. Já as endometrites envolvem apenas o endométrio e os tecidos glandulares e não apresentam sinais sistêmicos, sendo costumeiramente associadas a uma infecção crônica do útero no pósparto, geralmente com presença de bactérias patogênicas do tipo Arcanobacterium pyogenes. (Lewis,1997 e Bondurant, 1999).

Note-se que normalmente em estudos correlacionais o termo metrite é usado para denominar ambos casos (Sandals et al., 1979; Erb et al., 1984, 1985; Grohn et al., 1989; Oltenacu et al., 1983 e 1990; Correa et al., 1993; Emanuelson, 1993).

Desordens uterinas, principalmente infecções uterinas não específicas, reduzem a eficiência reprodutiva de vacas leiteiras. Em alguns rebanhos, $40 \%$ das vacas no pós-parto podem ser diagnosticadas e tratadas com infecções uterinas. Além de reduzir a eficiência reprodutiva, as infecções uterinas aumentam os custos de saúde do rebanho; freqüentemente reduzem o consumo de alimento, causam uma redução significativa na produção de leite e forçam os produtores a descartar vacas produtivas que poderiam permanecer no rebanho (Lewis, 1997).

As infecções uterinas podem ter um impacto considerável na rentabilidade de uma propriedade leiteira. Em 1986 calculou-se que o custo para cada vaca em lactação portadora de uma infecção uterina (metrite) era de US\$ 106 (Bartlett et al.,1986).

Clinicamente, o desafio é identificar quais dessas vacas acometidas apresentam verdadeiro risco de ter a fertilidade prejudicada. O meio mais comum de diagnóstico de infecções uterinas é a palpação transrectal do útero. Porém este método é subjetivo e freqüentemente falho devido a ocorrência de eventos normais e a variabilidade na involução uterina (Morrow et al., 1966; Gier \& Marion, 1968). Também é dificilmente associado com o desempenho reprodutivo (Studer \& Morrow, 1978; Miller et al., 1980; Lewis, 1997). 
Os resultados de diagnósticos obtidos através de vaginoscopia são mais fortemente associados com infecção bacteriana e com redução no desempenho reprodutivo (Miller et al, 1980; Dohmen et al., 1995); contudo esta ferramenta não é geralmente empregada devido ao fato de aumentar o risco de novas infecções, ocasionadas pelo mau uso da técnica. As biópsias de endométrio no pós parto constituem outra técnica usada, tendo demonstrado grande utilidade para avaliar o desempenho reprodutivo, mas a própria técnica está associada a efeitos danosos sobre a fertilidade (Bonnett et al., 1993).

A incidência das infecções uterinas apresentadas em diversos estudos varia consideravelmente em função de que muitos pesquisadores não descrevem os métodos de diagnóstico, a classificação das infecções uterinas, o período pós-parto durante o qual as infecções foram diagnosticadas, o número de partos das vacas, as características produtivas das vacas ou as práticas de manejo do rebanho (Lewis, 1997).

Um estudo demonstrou que de vacas examinadas entre o $5^{\circ}$ e $14^{\circ}$ dia pósparto em sete rebanhos, 36\% foram diagnosticadas com metrites, sendo que a variação entre rebanhos foi de 24,8 a 51,3\%, o que demonstra que aparentemente houve um efeito de rebanho (Markusfeld, 1987). Já em outro estudo com 31 rebanhos, os quais foram examinados uma única vez durante os primeiros 30 dias pós-parto, 7,8\% das vacas foram diagnosticadas com metrites, mas a variação da incidência entre rebanhos não foi informada, e a classificação de metrites incluiu endometrites, metrites e piometras (Curtis et al.,1985). Sendo assim, fica difícil estabelecer uma incidência média de infecções uterinas.

A maioria dos casos de metrites tem início no período pós-parto, durante a involução uterina (período em que o útero retorna ao tamanho normal, o que varia de 26 a 55 dias). Nesta fase é essencial que haja uma ótima higiene e manejo sanitário, pois neste estressante período a vaca apresenta-se extremamente vulnerável a inúmeras infecções.

Um grande número de microorganismos está implicado como causadores de metrites. Bactérias, fungos, vírus e protozoários são encontrados em úteros quando há quadros de metrites. 
O principal momento da contaminação, particularmente em relação a bactérias e fungos, ocorre durante o parto ou no pós-parto imediato. $\mathrm{O}$ trato reprodutivo está muito susceptível neste momento, especialmente se existirem traumas ou lesões na vagina e vulva, e se as defesas naturais do animal estiverem suprimidas.

Qualquer manipulação durante o parto pode facilmente introduzir estes organismos no útero. Já as infecções virais (IBR, BVD, leptospirose, etc.) geralmente atingem o útero pela via sistêmica. Uma outra forma das infecções alcançarem o útero ocorre durante a monta natural (campilobacteriose e tricomoniose).

Os sinais clínicos comuns nas metrites incluem a presença de descarga vaginal purulenta, odor e alterações nas paredes do útero (tamanho e consistência).

Alguns estudos relatam que vacas com grandes ECC possuem uma maior incidência de metrites, possivelmente devido ao fato das vacas gordas possuírem a musculatura uterina fraca.

\subsection{Efeitos do escore de condição corporal sobre a produção, reprodução e sanidade}

Devido a desequilíbrios entre o consumo de energia e a energia usada para produção de leite, a condição física dos animais é alterada ao longo do ciclo de lactação (Fergunson, 1992; Otto et al., 1991).

O escore de condição corporal (ECC) é uma ferramenta de manejo que pode ser usada para monitorar a quantidade e a mobilização de tecido adiposo ajudando na indicação de animais que se encontram em balanço energético negativo (Butler \& Smith, 1989; Edmonson et al., 1989; Garnsworthy, 1988; Gearhart et al., 1990; Nebel \& McGilliard, 1993).

Extremos da condição física do animal, obesidade ou emaciação, quando do parto, podem predispor vacas a problemas reprodutivos, produtivos e de sanidade. 
O escore de condição corporal (ECC) demonstra a quantidade de reservas corporais acumuladas especialmente sob a forma de gordura (Weaver, 1991). De 50 a $70 \%$ da gordura corporal nas vacas da raça Holandesa encontra-se nos tecidos subcutâneo e muscular e de 23 a 30\% na gordura intra-abdominal. A gordura subcutânea é mobilizada primeiro, a intra-abdominal em segundo e por último a intramuscular (Lamond, 1970).

O método utilizado consiste em estabelecer, mediante inspeção e palpação, a cobertura de músculo e gordura subcutânea nas áreas dos processos transversos lombares e da fossa ísquio-caudal, classificando o animal por meio de pontuações de um (extremamente magro) a cinco (obeso).

Nos Estados Unidos o sistema de escores mais utilizado é aquele proposto por Wildman et al. (1982), com escala de 1 a 5, e intervalos de 0,25 pontos para medir o escore de condição corporal (Chalupa et al., 1996; Edmonson et al., 1989).

É recomendada a determinação do ECC idealmente em quatro oportunidades durante o ciclo produtivo da vaca leiteira (secagem, parto, pico de lactação e momento da cobertura).

Os valores recomendados são de 3,0 a 4,0 desde que a vaca é seca até o parto, diminuindo para 2,5 a 3,0 até os dois meses de lactação e depois recuperando aos três meses de lactação para 2,5 a 3,5 pontos (Weaver, 1991). O mais importante é que a variação do ECC entre dois períodos nunca seja superior a 1,0 ponto, sendo a variação ideal a de 0,5 .

\subsubsection{Escore de Condição Corporal e Produção de Leite}

Muito da informação que relaciona o ECC com a produção de leite baseia-se em estudos desenvolvidos no Reino Unido (Garnsworthy, 1988). Esses estudos utilizaram pequeno número de vacas, com raças e estratégias de manejo diferentes dos usados nos EUA. Tais estudos prévios usaram uma escala de quatro pontos, em lugar da 
escala vigente de cinco pontos para avaliar o ECC. Estes fatores dificultam a extrapolação dos resultados para as condições americanas e também para as brasileiras, porque utilizamos a escala de cinco pontos e possuímos rebanhos com diferente genética e tipo de manejo.

Em uma revisão de trabalhos realizados no Reino Unido, Garnsworthy (1988) sugeriu que a relação entre ECC ao parto (ECCP) e a produção de leite foi variável, e que vacas com ECC maior ao parto geralmente perdem mais unidades de condição corporal durante a lactação, o que poderia influenciar negativamente a produção de leite.

Vacas que estão gordas ou super condicionadas ao parto apresentam maior risco de produzirem menos leite e terem mais problemas reprodutivos e de saúde (Boisclar et al., 1986; Fronk, et al., 1980; Gearhart et al., 1990 e Morrow, 1975); porém vacas gordas ou super condicionadas (que possam representar os extremos do ECC) não são encontradas costumeiramente em rebanhos de alta produção.

Boisclar et al., (1986) e Gearhart et al., (1990) em seus estudos não conseguiram isolar nenhuma relação entre os problemas de saúde ou reprodutivos dos animais com a variação do ECC.

As conclusões de estudos mais recentes, realizados nos EUA, que investigaram o ECC e produção de leite, também são muito variáveis.

Em um estudo realizado com 66 vacas constatou-se que as produções diárias de leite e as produções acumuladas das vacas que pariram com um ECC superior ou inferior a 3,5 em uma escala de cinco pontos não foram diferentes (Ruegg et al., 1992). A média de produção de leite diária também não foi influenciada pela quantidade de condição corporal (CC) perdida.

Ferguson (1992) em seu estudo não informou qualquer influência significativa do ECC ao parto sobre a produção de leite de 1300 vacas. Pedron et al., (1993) em estudo realizado na Itália indicaram que o ECC ao parto não era importante para a produção total de leite, mas que as mudanças no ECC influenciaram o pico de produção e a forma da curva de lactação. 
Contrário a isto, Waltner et al. (1993) citam que o ECC ao parto e as alterações no ECC durante a lactação são capazes de afetar a produção total de leite corrigido (3,5\% de gordura) para os 90 dias da lactação.

Ruegg (1994) não encontrou diferenças na produção de leite corrigida para os 305 dias de lactação ou no pico de produção ao estudar 429 vacas de 13 rebanhos canadenses, baseando-se no ECC ao parto.

O escore de condição corporal ao parto aparenta ter pequena influência sobre a produção de leite. As alterações no ECC, que estão relacionadas ao ECC ao parto, influenciaram porém as produções de leite de diversos estudos (Domecq et al., 1997a).

O efeito do ECC no momento da secagem (ECCS) ou as mudanças de ECC durante o período seco (pré-parto) não foram incluídas em estudos prévios, mas autores afirmam que podem influenciar a produção de leite (Domecq et al., 1997a).

A taxa de aumento da produção de leite no início da lactação é importante para a produção total da lactação e pode refletir com mais precisão as mudanças na dinâmica biológica. A taxa de aumento da produção de leite pode ser associada com o ECC ou com as alterações do ECC (Gearhart et al., 1990).

Vacas que apresentam um ECC maior tendem a perder mais condições corporais (gastam o excesso de reserva energética disponível na produção de leite) do que vacas com ECC baixo (Butler \& Smith, 1989; Erb et al., 1985; Gearhart et al., 1990; Sorenson \& Enevoldsen. 1991). As vacas mais magras são capazes de aumentar a ingestão de matéria seca mais rápido e alcançar o balanço energético positivo mais cedo que as vacas mais gordas (Gearhart et al., 1990).

Em um dos poucos trabalhos realizados no Brasil relacionado com essa temática, Lago et al. (2001) mostraram que o ECC não influenciou a produção de leite das vacas até a $8^{\mathrm{a}}$ semana de lactação. 


\subsubsection{Escore de Condição Corporal e Reprodução}

Estima-se que $80 \%$ das vacas que se encontram no período inicial da lactação sofrem com o balanço energético negativo (Butler \& Smith, 1989; Garnsworthy, 1988; Gearhart et al., 1990; Nebel \& McGilliard, 1993 e Van Saun, 1991), respondendo de forma individual ao balanço energético negativo através de diferentes mecanismos, tais como o aumento no consumo de alimento, a mobilização de tecido adiposo e menor produção de leite (Butler \& Smith, 1989; Garnsworthy, 1988 e Nebel \& McGilliard, 1993).

O desempenho reprodutivo destas vacas, particularmente a probabilidade de concepção, pode ser associado negativamente com a magnitude e severidade do balanço energético negativo no início da lactação (Butler \& Smith, 1989 e Nebel \& McGilliard, 1993).

O ECC constitui uma ferramenta muito bem aplicada no manejo reprodutivo uma vez que pode ser usado para monitorar a mobilização de tecido adiposo, assim indicando o equilíbrio energético dos animais e servindo para predizer o estado reprodutivo dos animais (Butler \& Smith, 1989; Edmonson et al., 1989; Garnsworthy, 1988; Gearhart et al., 1990 e Nebel \& McGilliard, 1993).

Se a concepção é relacionada a ECC, a dimensão das alterações do ECC durante o início de lactação pode ser usada para determinar se as metas nutricionais são alcançadas e identificar potenciais problemas nutricionais, sanitários e reprodutivos (Butler \& Smith, 1989; Garnsworthy, 1988 e Nebel \& McGilliard, 1993).

Segundo vários estudos, o ECC de uma vaca ao parto parece não ter nenhuma relação com concepção ou o número de serviços por concepção (Butler \& Smith, 1989; Nebel \& McGilliard, 1993; Pedron et al., 1993; Ruegg et al., 1992 e Ruegg \& Milton, 1995).

Garnsworthy (1988) em seu estudo concluiu que o ECC ao parto, ou ECC no momento da cobertura não esteve relacionado com a taxa de concepção. Contudo, as perdas de CC entre o parto e a cobertura influenciaram negativamente a concepção. 
Butler \& Smith (1989), Ferguson (1992), e Ferguson \& Otto (1989) obtiveram resultados semelhantes de concepção ao primeiro serviço (CPS) para vacas agrupadas de acordo com perdas de ECC. Vacas que perderam de 0,5 a 1,0 ponto de ECC tiveram a taxa de CPS de $53 \%$, e as vacas que perderam $>1,0$ ponto de ECC entre 0 parto e a cobertura tiveram uma taxa de $17 \%$.

Ruegg \& Milton (1995) em um estudo com vários rebanhos identificaram uma associação marginal $(\mathrm{P}=0,09)$ entre as perdas de ECC e número de coberturas. Já em outro estudo, Ruegg et al. (1992) indicaram que as perdas de ECC não estiveram relacionadas com o número de coberturas por concepção.

Vários estudos anteriormente citados usaram o número de coberturas (ou serviços) por concepção para investigar as relações entre ECC e a fertilidade das vacas. Contudo, o número de serviços por concepção pode não ser o melhor indicador do papel do ECC no sucesso ou fracasso da concepção porque a dimensão e a duração do balanço energético negativo, monitorado pelo ECC, muda ao longo da lactação.

Um método mais direto para avaliar a relação entre ECC e concepção foi utilizado por Butler \& Smith (1989), Ferguson (1992), e Ferguson e Otto (1989), os quais apenas consideraram a concepção ao primeiro serviço (CPS). Normalmente, com o avanço da lactação, a dimensão e a duração do balanço energético negativo é reduzida. Se o balanço energético negativo (monitorado pelas mudanças do ECC) está associado com CPS, a associação provavelmente estaria no início de lactação quando o balanço energético é muito mais acentuado, devendo-se assim concentrar as pesquisas neste período.

O uso do ECC para monitorar mudanças no balanço energético negativo durante o período seco e durante os primeiros 30 dias da lactação (período periparto) pode ser importante para CPS (Domecq et al., 1995 e 1997b).

A associação entre o ECC do periparto e CFS não foi examinada em vacas com grandes produções (>11.000 kg / ano), sendo que estas vacas são mais propensas a um acentuado balanço energético negativo e a maiores diminuições no ECC (Nebel \& McGilliard, 1993). 
A maioria dos estudos citados acima não controlaram as variáveis biológicas ou de manejo, tais como as estações do ano, a produção de leite e as desordens sanitárias que também podem influenciar muito a concepção e os resultados dos estudos.

\subsubsection{Escore de Condição Corporal e Sanidade}

Dados provenientes de diversas pesquisas e estudos de observação sugerem que as mudanças no ECC podem influenciar a saúde e a produtividade das vacas leiteiras (Gearhart et al., 1990).

A rápida mobilização das reservas corporais logo após o parto pode ser associada com uma incidência mais alta de desordens metabólicas, acarretando prejuízos na fertilidade e outros problemas de saúde (Morrow et al., 1979; Perkins et al., 1985).

Em 1979, Zamet et al. determinaram que o aumento da mortalidade e complicações no pós-parto podem acontecer em vacas que sofreram diminuição de peso durante o período seco.

Vacas menos produtivas têm mais dias vazios e com isto ganham melhores condições corporais durante o decorrer da lactação (Wildman et al., 1982). Vacas com grandes produções devem parir com quantia adequada de reservas corporais para que a mobilização ajude a satisfazer as exigências de energia e proteína para produção de leite no início da lactação.

Para Gearhart et al. (1990), que analisaram dados de ECC coletados em produtores comerciais, o ECC pode ser relacionado à saúde das vacas; animais super condicionados na secagem tiveram o risco aumentado de apresentar problemas reprodutivos e de laminite na lactação subseqüente. Estes resultados sugerem que embora possam ser feitos ajustes no ECC durante o período seco, tais correções podem afetar a saúde de vaca adversamente ao parto; portanto este manejo não pode ser um 
substituto para correção de erros no momento da secagem, devendo ser evitados altos ECC em qualquer fase da lactação.

Waltner et al. (1993), revisando diversos estudos, citam que a taxa e a quantia de perda de gordura corporal são os indicadores mais específicos de suscetibilidade de doença. Vacas super condicionadas ao término de lactação ou aos 30 DEL são mais propensas a cistos ovarianos, infecções de casco e metrites. Contudo, quando realizaram seu próprio estudo, Waltner et al., (1993) não conseguiram relacionar o ECC a variáveis de reprodução ou doença; porém justificaram estes resultados afirmando que o grau de variação do ECC provavelmente está limitado no rebanho estudado devido ao manejo intensivo. Rebanhos com maiores variações no ECC exibem uma relação entre ECC e reprodução e doença.

Conclui-se claramente que o ECC deve ser suficiente ao parto para permitir a máxima produção e saúde, mas que o ECC excessivo ao parto, a perda excessiva de ECC durante a lactação e a diminuição da produção de leite indicam desempenho sub ótimo. 


\section{IMPORTÂNCIA DAS DESORDENS DO PERIPARTO E SEUS FATORES DE RISCO SOBRE A PRODUÇÃO DE LEITE DE VACAS HOLANDESAS}

Resumo

Este estudo investigou efeitos de ocorrências sanitárias periparto e seus respectivos fatores de risco sobre a produção de leite, no pico e aos 305 dias em lactação. Foram utilizadas 512 vacas holandesas de um rebanho comercial do Estado de São Paulo tiveram seu desempenho sanitário e nutricional acompanhados desde o início do período pré-parto até o final da lactação. A ocorrência de doenças, os escores de condição corporal (no pré-parto e parto), as produções e composições do leite foram registradas. Para análise estatística dos dados, foram utilizadas a regressão logística e a análise de regressão múltipla. Os resultados obtidos demonstraram que as doenças do periparto e seus fatores de risco afetaram a produção de leite com efeitos diferentes em função do número de lactações, exigindo desta maneira maior cuidado com adoção de medidas profiláticas para se evitar as doenças e maximizar a produção de leite dos animais.

Palavras chave: doenças do periparto, doenças do parto, produção de leite, vacas leiteiras. 


\title{
The importance of peripartum health disorders and risk factors on Holsteins cows milk production
}

\author{
Summary
}

This study evaluates the effects of peripartum health disorders on milk production, during the peak and at 305 days of lactation. Data were collected from a commercial herd of holstein cows, recording nutritional and health performance like, diseases, body condition scores (at drying off and calving), daily production and milk composition, during pre calving to the end of lactation. Data recorded were processed through statistic methods: logistic regression and multiple regression analysis. Results of study showed a directly correlation from peripartum diseases and milk production. Different effects were found, based on peripartum diseases and lactation order, requiring attention on prophylactics actions to be taken in order to avoid disease and maximize milk production.

Keys words: peripartum health disorders; calving diseases; milk production; dairy cows

\subsection{Introdução}

O constante aumento na produção de leite ocorrido nas últimas décadas pode ser atribuído à combinação de melhorias no manejo, na nutrição e na intensa seleção genética.

Por outro lado, essas melhorias trouxeram impactos negativos, tais como aumento nas condições de estresse dos animais, e sob certas condições, aumento na ocorrência de desordens metabólicas e infecciosas no período do periparto (Erb \& Grohn, 1988; Emanuelson \& Oltenacu, 1998 e Grohn et al., 1990). 
Para que esses efeitos indesejados sejam minimizados, há necessidade do conhecimento acurado dos fatores que afetam a sanidade da vaca (o número de lactações, a estação do ano ao parto, o histórico sanitário), e as associações entre os problemas sanitários e a condição nutricional dos animais.

O estudo dos efeitos do ambiente, como das estações do ano (inverno e verão), e do manejo nutricional, utilizando-se o escore de condição corporal (ECC) nas diferentes fases da lactação (secagem e parto), procurando identificar os fatores de risco das doenças do periparto, poderá gerar informações úteis na elaboração de estratégias para redução da ocorrência das mesmas, diminuindo o efeito destas sobre o pico de produção e aumentando a produção de leite ao longo da lactação (Fergunson, 1992).

A redução na capacidade produtiva dos animais ocasionada pela ocorrência de doenças no periparto resulta em grande perda econômica. Pesquisadores demonstraram queda na produção de leite aos 305 dias, na ordem de 11\% em vacas com deslocamento de abomaso (Fleisher et al., 2001), sendo este efeito maior durante os primeiros 120 dias da lactação (Raizman \& Santos, 2002).

A retenção de placenta aumenta o risco de ocorrência de metrites, resultando em redução da fertilidade, aumento dos dias para concepção e aumento no risco de descarte, além de acarretar diminuição da produção de leite. São evidentes, as graves conseqüências econômicas. O custo estimado por caso, somando-se os custos de tratamento e perda de produção, foi de US\$ 285 (Guard, 1996).

A importância da hipocalcemia para a atividade leiteira não é bem quantificada devido à pequena incidência de casos; além disso, o tratamento é eficaz e facilmente realizado. Contudo é considerada uma doença economicamente importante, podendo reduzir a vida produtiva de uma vaca em 3 ou 4 anos (Payne, 1968).

Para cada caso de cetose clínica é calculada uma perda de produção de 200kg por lactação, sendo que essas perdas podem ser maiores quando somadas às perdas causadas pela cetose sub-clínica (Schlatter, 1997). Bartlett et al. (1986), calcularam que o custo para cada vaca em lactação portadora de uma infecção uterina (metrite) era de US\$106. 
Diversos estudos demonstraram redução na produção de leite, aumento no custo de produção devido a despesas com veterinário e medicamentos, e maior número de descarte de animais acometidos por desordens sanitárias no periparto (Fleisher et al., 2001; Guard et al., 1996 e Van Dorp et al., 1998).

O objetivo deste estudo foi avaliar a associação existente entre as doenças do periparto, e destas com a época do ano ao parto e os escores de condição corporal. Procurou-se também determinar quais desses fatores e doenças afetam o pico e a produção de leite em 305 dias de lactação, quantificando seus impactos.

\subsection{Material e Métodos}

\subsubsection{Animais e instalações}

Neste estudo foi utilizado dados provenientes de uma fazenda comercial (com 600 animais em lactação), localizada no município de Araras, no Estado de São Paulo, região de clima subtropical, com temperatura máxima de $35^{\circ} \mathrm{C}$ em dezembro, janeiro e fevereiro e mínima de $10{ }^{\circ} \mathrm{C}$ em maio, junho e julho. As vacas estiveram confinadas em free-stalls dotados de ventiladores e aspersores (posicionados acima da linha dos canzis), acionados automaticamente quando a temperatura ambiente ultrapassava $23^{\circ} \mathrm{C}$. As vacas em lactação eram divididas em oito grupos de acordo com a produção e número da lactação. As vacas primíparas foram mantidas no mesmo grupo durante toda a lactação.

Foram utilizados 15.613 dados zootécnicos e sanitários provenientes das lactações de 512 fêmeas bovinas, multíparas e primíparas, da raça Holandesa, com

produção média no pico de 43,3 kg, média de produção acumulada aos 305 dias de 9.982 kg e média de 61 dias em lactação até o pico. 
Todos os animais paridos entre outubro de 2000 e novembro de 2001 foram incluídos no estudo. As vacas multíparas entraram no estudo no momento da secagem e as novilhas, 60 dias antes da data prevista do parto.

A coleta de dados foi concluída quando os animais encerraram a lactação ou aos 305 dias em lactação, ou o que primeiro aconteceu. As vacas descartadas ou mortas durante o período do estudo não tiveram seus dados analisados (22 animais).

\subsubsection{Alimentação e monitoramento nutricional}

Os animais foram alimentados sete vezes por dia, ocorrendo o primeiro fornecimento às 5:00 horas e o último às 21:00 horas. Todos os animais em lactação receberam uma única ração completa (TMR - total mixed ration), composta com os ingredientes citados na Tabela 1, e com a composição bromatológica citada na Tabela 2. Após 150 dias em lactação todas as vacas receberam a cada 12 dias, injeções de 500 mg de somatotropina recombinante bovina, via subcutânea.

As dietas foram formuladas seguindo as recomendações do NRC Dairy Cattle (NRC, 2001), sendo calculadas e avaliadas com auxílio do software Spartan Ration Evaluator - Balancer, versão 2.0, 1992 (MSU, 1992). Durante o período do estudo os ingredientes utilizados na dieta foram substituídos conforme a disponibilidade de mercado e a flutuação de preços.

Para a coleta de amostras representativas da dieta, mensalmente, foram estendidas na extensão do cocho três lonas plásticas (no início, meio e final do cocho) com dimensões de 1,5m x 1,0m, antes da distribuição de alimento aos animais. Após a passagem do vagão distribuidor de ração completa, as amostras de cada uma das lonas plásticas foram misturadas e homogeneizadas, sendo uma amostra da dieta retirada deste volume, a qual foi mantida armazenada em câmara fria até o momento da análise laboratorial. Através das análises laboratoriais foram determinados os teores de proteína

bruta, extrato etéreo, matéria seca, matéria mineral, fibra detergente neutro e fibra detergente ácido, segundo a metodologia proposta por Goering e Van Soest (1970). 
Essas análises foram realizadas mensalmente no laboratório de análises bromatológicas da FMVZ-USP.

Tabela 1. Composição da dieta das vacas em lactação por ingredientes em \% da matéria seca

\begin{tabular}{lc}
\hline \multicolumn{1}{c}{ Ingrediente } & $\% \mathrm{MS}$ \\
\hline Silagem de milho & 36,60 \\
Pré-secado de “Coast Cross” & 9,00 \\
Polpa cítrica peletizada & 11,18 \\
Gérmen de milho & 13,40 \\
Farelo de soja & 11,98 \\
Protenose de milho & 2,22 \\
Silagem de grão de milho com alta umidade & 12,51 \\
Concentrado mineral e vitamínico* & 2,22 \\
Sais de sabões de cálcio (gordura protegida) & 0,89 \\
\hline
\end{tabular}

*Composição: Ca 17,69 \%; Pt 3,33 \%; Mg 4,60 \%; Na 8,67 \%; K 3,58 \%; Cl 10,22 \%; S 1,43\%; Vit. A (1000 UI/kg) 221,28; Vit. D3 (1000 UI/kg) 34,23; Vit. E (UI/kg) 885,12; Fe (mg/kg) 1.545,42; Cu (mg/kg) 715,21; Mn (mg/kg) 1.442,12; Zn (mg/kg) 2.314,37; Co (mg/kg) 5,21; I (mg/kg) 21,02; Se (mg/kg) 10,46; Fl (mg/kg) 333,50; monesina (mg/kg) 352,80.

Tabela 2. Composição bromatológica média da dieta das vacas em lactação, durante o período experimental em \% da matéria seca

\begin{tabular}{lc}
\hline \multicolumn{1}{c}{ Nutriente } & Bromatológica \\
\hline Matéria seca (\%) & 51,2 \\
Proteína bruta & 15,9 \\
Extrato etéreo & 3,8 \\
Fibra em detergente ácido & 21,4 \\
Fibra em detergente neutro & 36,8 \\
Carboidratos não estruturais & 37,7 \\
Matéria mineral & 5,9 \\
\hline
\end{tabular}


O acompanhamento da nutrição dos animais foi realizado através da avaliação do consumo de matéria seca (CMS) e do controle do tamanho de partículas da dieta. O consumo de matéria seca foi obtido através das pesagens diárias, da dieta fornecida e das sobras de cocho de cada lote. Com estes dados foi calculado o consumo diário por animal. O valor do consumo de matéria seca utilizado neste estudo foi a média dos consumos diários de cada mês.

O tamanho de partículas da dieta foi avaliado através do Separador de Partículas da Universidade da Pensilvânia, seguindo a metodologia dos mesmos (Lammers et al., 1996). As partículas foram determinadas como a porção retida na peneira superior (grossa - 19mm), na peneira média (média - 8mm) e o restante da amostra (fina), sendo expressos em porcentagens do total. Essa avaliação foi feita mensalmente, nos mesmos dias das coletas de amostras da dieta para as análises bromatológicas.

A Tabela 3 apresenta a análise descritiva (relativa 12 amostragens) das variáveis relacionadas aos consumos de matéria seca (CMS) e aos tamanhos de partículas.

Tabela 3. Análise descritiva das variáveis relacionadas aos consumos de matéria seca e aos tamanhos de partículas

\begin{tabular}{|c|c|c|c|c|c|c|}
\hline & Variáveis & Média & D. Padrão & C. V. (\%) & Mínimo & Máximo \\
\hline 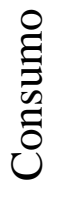 & $\begin{array}{c}\text { Matéria Seca } \\
\text { (kg/dia) }\end{array}$ & 22,46 & 1,73 & 7,72 & 19,10 & 24,82 \\
\hline \multirow{3}{*}{ 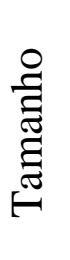 } & Grossa (\%) & 25,13 & 3,15 & 12,52 & 21,99 & 32,28 \\
\hline & Media (\%) & 34,50 & 1,85 & 5,37 & 32,71 & 38,02 \\
\hline & Fina (\%) & 40,37 & 4,66 & 11,54 & 29,70 & 45,23 \\
\hline
\end{tabular}


Os valores médios obtidos para o CMS e para o tamanho de partículas são semelhantes com os valores médios encontrados na literatura e são considerados normais para vacas da raça Holandesa, criadas em regime intensivo (Heinrichs et al., 1999; Hettinga, 1989 e Linn, 1991).

\subsubsection{Coleta de dados experimentais}

\subsubsection{Produção de leite}

As vacas foram ordenhadas três vezes ao dia, em sala de ordenha informatizada. As produções de leite de cada vaca foram medidas e registradas eletronicamente via computadores.

Os cálculos do pico de produção, dia do pico e da produção corrigida para 305 dias em lactação foram realizados utilizando-se o software “Gerencial” do Programa de Análise de Rebanhos Leiteiros da Clínica do Leite, ESALQ-USP.

\subsubsection{Desordens Sanitárias}

Todas as doenças foram diagnosticadas e registradas pelo mesmo veterinário. Estes dados foram coletados em visitas diárias à fazenda. As doenças foram codificadas como ocorridas ou não ocorridas ( 0 = não e $1=\operatorname{sim}$ ). Ocorrências repetidas ou de um mesmo diagnóstico em uma mesma vaca não foram registradas; desta forma, o cálculo das incidências das doenças levou em consideração apenas a primeira ocorrência de cada doença. As doenças de interesse para o estudo foram: hipocalcemia, cetose clínica, deslocamento de abomaso, retenção de placenta e metrites primárias ou secundárias. As definições das desordens sanitárias são demonstradas na tabela 4 e são semelhantes às utilizadas em outros estudos.

Os dados sobre as doenças foram coletados após exame clínico de todos animais: 24 horas após o parto, entre o dia 8 e 10 da lactação e quando os animais apresentaram sinais clínicos de acometimento sistêmico ou alterações bruscas na produção de leite. 
Tabela 4. Definições das desordens sanitárias avaliadas

\begin{tabular}{|c|c|}
\hline Desordem & Definição \\
\hline Hipocalcemia & $\begin{array}{l}\text { Fraqueza, baixa temperatura e resposta favorável a terapia } \\
\text { endovenosa com cálcio. }\end{array}$ \\
\hline Retenção de Placenta & Retenção das membranas fetais > 18 h após o parto. \\
\hline Cetose Subclínica & $\begin{array}{l}\text { Determinação da presença de corpos cetônicos na urina } \\
\text { com auxílio de fita reagente (Ketostic - Bayer }{ }^{\circledR} \text { ). }\end{array}$ \\
\hline Metrite Primária & $\begin{array}{l}\text { Descarga abundante e útero com tamanho anormal } \\
\text { durante a palpação trans-rectal, diagnosticada no primeiro } \\
\text { mês de lactação (checada a partir de } 8 \text { dias pós parto). }\end{array}$ \\
\hline Metrite Secundária & Metrite diagnosticada após caso de retenção de placenta. \\
\hline Deslocamento de Abomaso & $\begin{array}{l}\text { Som metálico durante a auscultação abdominal e correção } \\
\text { cirúrgica. }\end{array}$ \\
\hline
\end{tabular}

\subsubsection{Escore de condição corporal (ECC)}

Toda avaliação do escore de condição corporal (ECC) foi feita por um único indivíduo, segundo a metodologia visual descrita por Wildman et al., (1982). As avaliações foram feitas no momento da entrada dos animais no estudo (secagem) e ao parto.

A avaliação do ECC no momento da entrada dos animais no experimento (ECC à secagem), foi feita no dia em que os animais foram transferidos para o lote préparto. Desta forma, tanto os animais multíparos (que foram tratados com a terapia da vaca seca, sessenta dias antes do parto), como os primíparos (transferidos para o lote pré-parto 60 dias antes da data prevista do parto), tiveram o escore de condição, determinado como ECC à secagem, avaliado desta maneira.

As medidas do ECC ao parto foram realizadas no dia após o parto, no momento do exame clínico pós-parto a que todos animais foram submetidos. 


\subsubsection{Análise estatística}

As análises estatísticas descritivas e a modelagem foram realizadas utilizando-se o sistema de análises estatísticas SAS (1999). Para a determinação das associações entre as doenças e da associação destas com fatores de manejo e ambiente foram realizadas análises de regressão logística, utilizando-se, para tal, o procedimento LOGISTIC do SAS ${ }^{\circledR}$ (1999), calculando-se a razão das chances, também denominada de odds ratio.

A razão chance (ou odds ratio) é uma medida da força de associação entre variáveis independentes e dependentes, que é extensivamente usada em estudos epidemiológicos (Erb et al., 1985 e Gearhart et al., 1990). Os odds ratio (OR) são o “log” natural do parâmetro estimado obtido na análise de regressão logística. Um odds ratio de 1,0 sugere que não existe alguma associação entre as variáveis dependentes e independentes; valores maiores ou menores que 1,0 indicam associação positiva ou negativa entre as variáveis, respectivamente (Domecq et al., 1997).

Já para a determinação dos fatores responsáveis por alterações no pico e na produção de leite estimada para 305 dias foi efetuada a análise de regressão múltipla, utilizando-se o método de seleção de variáveis "stepwise”, através do procedimento REG do pacote estatístico SAS ${ }^{\circledR}$ (1999).

\subsection{Resultados e Discussão}

Ao todo, neste estudo, foram computados 285 diagnósticos veterinários positivos. A incidência das doenças encontrada é apresentada na Tabela 5. Estas incidências estão de acordo com dados contidos na literatura, referentes a rebanhos com os mesmos níveis de produção leiteira e condições semelhantes de manejo (Domecq et 
al., 1997; Erb \& Grohn, 1988; Gearhart et al., 1990; Grohn et al., 1990; Markusfeld, 1990 e Risco, 1992).

As metrites primárias e as retenções de placenta foram as doenças mais presentes neste rebanho, ocorrendo poucos casos de hipocalcemia e deslocamento de abomaso. A grande incidência de metrites primárias pode ser explicada devido ao manejo adotado nesta propriedade, onde o diagnóstico de metrites é realizado precocemente (a partir do oitavo dia pós parto) aumentando assim muito o número de animais acometidos, neste índice não foi considerado a necessidade ou não do tratamento dos animais.

Tabela 5. Incidência de desordens sanitárias em vacas da raça Holandesa de alta produção comparado com dados da literatura

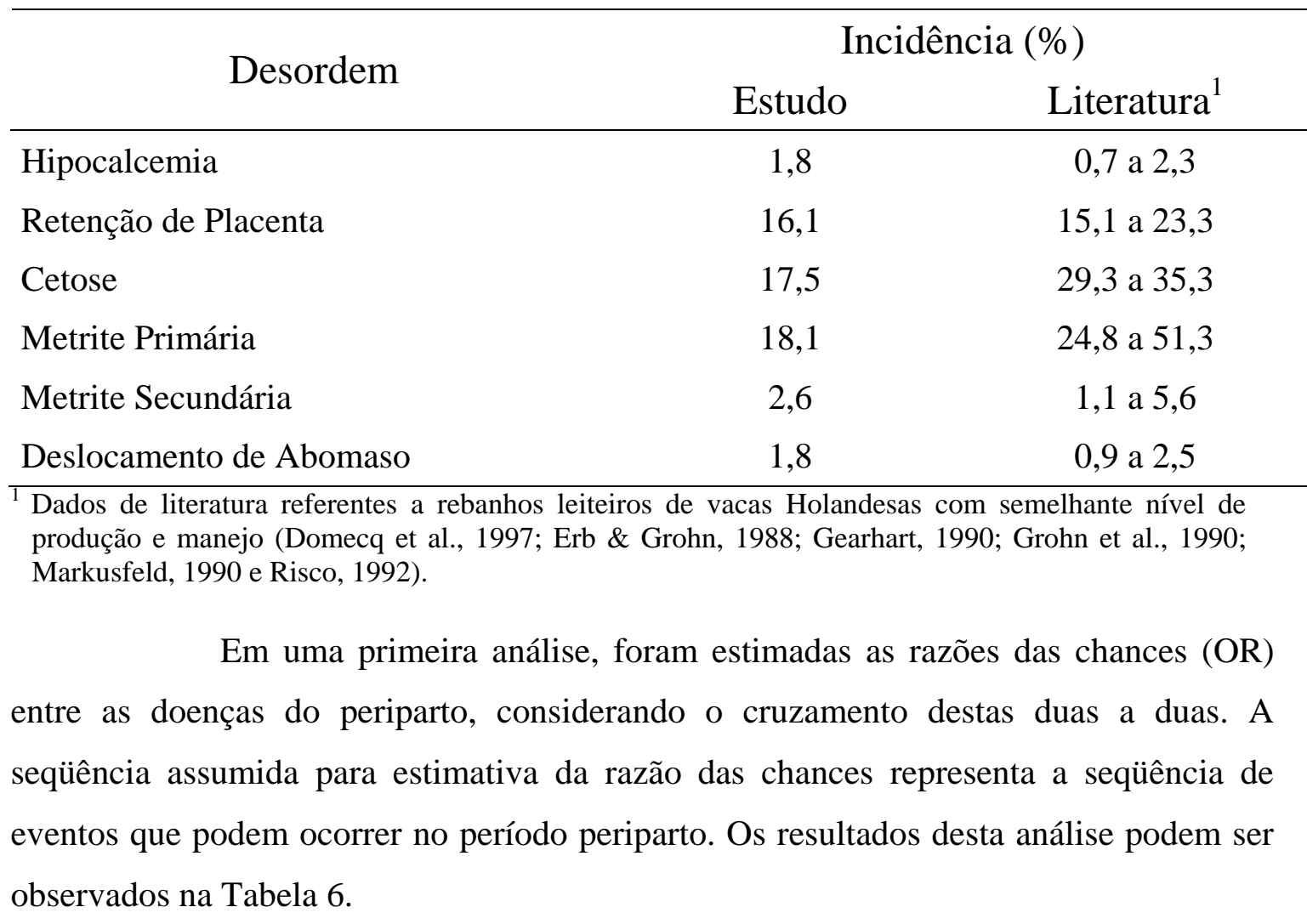


Tabela 6. Associação entre desordens primárias e secundárias (razão de chances) em vacas da raça Holandesa de alta produção

\begin{tabular}{|c|c|c|c|c|c|}
\hline \multirow[b]{2}{*}{ Desordem Primária } & \multicolumn{5}{|c|}{ Desordem Secundária } \\
\hline & $\begin{array}{c}\text { Retenção de } \\
\text { Placenta }\end{array}$ & Cetose & $\begin{array}{l}\text { Metrite } \\
\text { Primária }\end{array}$ & $\begin{array}{c}\text { Metrite } \\
\text { Secundária }\end{array}$ & $\begin{array}{c}\text { Deslocamento } \\
\text { de Abomaso }\end{array}$ \\
\hline Hipocalcemia & $4,33^{* *}$ & & & & \\
\hline Retenção de Placenta & & & $0,39 * *$ & $4,74^{* * *}$ & \\
\hline Cetose & & & $1,73^{* *}$ & & $6,17 * * *$ \\
\hline Metrite primária & & & & & \\
\hline Metrite secundária & & & & & $4,88 *$ \\
\hline
\end{tabular}

* = significativo pelo Teste de $\chi^{2}$ ao nível de $10 \%(\mathrm{p} \leq 0,10)$;

** = significativo pelo Teste de $\chi^{2}$ ao nível de $5 \%(\mathrm{p} \leq 0,05)$;

*** = significativo pelo Teste de $\chi^{2}$ ao nível de $1 \%(\mathrm{p} \leq 0,01)$.

Vacas com hipocalcemia tiveram 4,33 vezes $(\mathrm{p} \leq 0,05)$ mais chances de reterem as membranas fetais, sendo estes resultados semelhantes aos obtidos em vários estudos (Bendixen et al., 1987; Curtis et al., 1985; Dohoo \& Martin, 1984 e Markusfeld, 1984 e 1990).

Neste estudo, e em outros (Correa et al., 1993; Curtis et al., 1985; Erb et al., 1984; Emanuelson \& Oltenacu, 1998; Erb \& Grohn, 1988; Grohn et al., 1990; Markusfeld, 1984), a cetose foi fator de risco para deslocamento de abomaso (OR =6,17 e p $\leq$ 0,01). A metrite secundária, considerada como uma complicação decorrente da retenção de placenta, foi também identificada como fator de risco para o deslocamento de abomaso $(\mathrm{OR}=4,88$ e $\mathrm{p} \leq 0,05)$.

A relação entre a cetose e o deslocamento de abomaso é classificada como bidirecional, pois o deslocamento de abomaso também pode ocasionar a cetose (Curtis et al., 1985, Dohoo \& Martin, 1984).

As metrites primárias $(\mathrm{OR}=1,73$ e $\mathrm{p} \leq 0,05)$ foram relacionadas como fatores de risco para cetose. Isto pode ser explicado pelo fato dos animais doentes, acometidos por metrites, estarem sujeitos a menor ingestão de matéria seca, consumindo suas próprias reservas corporais, sendo mais susceptíveis a cetonúria (Curtis et al., 1985; Emanuelson \& Oltenacu, 1998). 
Confirmando o esperado, vacas com retenção de placenta tiveram 4,74 (p $\leq 0,01)$ vezes mais chances de terem metrite secundária, e 0,39 $(\mathrm{p} \leq 0,10)$ vezes menores riscos de terem metrite primária.

Em uma segunda parte da análise estatística foram associadas as desordens do periparto com o número das lactações (primíparas e multíparas), as estações do ano ao parto (verão ou inverno) e ECC (ao parto e antes do parto). Esta análise gerou o modelo de regressão logística final para cada uma das desordens estudadas.

As estimativas da razão das chances para os fatores de risco de cada doença, isolados como significativos pelo modelo, considerando-se um nível mínimo de significância de $10 \%$ (p $\leq 0,10)$, são apresentados na Tabela 7.

Tabela 7. Estimativas da razão das chances para os fatores de risco segundo o modelo final da regressão logística para cada uma das desordens do periparto em vacas da raça Holandesa de alta produção

\begin{tabular}{|c|c|c|c|}
\hline Desordens & Fatores de Risco & $\begin{array}{c}\text { Razão das } \\
\text { chances }\end{array}$ & $\mathrm{P}^{1}$ \\
\hline \multicolumn{4}{|l|}{ Hipocalcemia } \\
\hline \multirow[t]{3}{*}{$(n=09)$} & Multípara vs primípara & 1,48 & 0,0542 \\
\hline & Inverno vs Verão & 7,69 & 0,0676 \\
\hline & R. Placenta vs não & 4,35 & 0,0435 \\
\hline \multicolumn{4}{|l|}{ R. Placenta } \\
\hline$(n=79)$ & Multípara vs primípara & 1,33 & 0,0005 \\
\hline \multicolumn{4}{|l|}{ Cetose } \\
\hline$(n=86)$ & ECC ao parto & 2,04 & 0,0256 \\
\hline \multicolumn{3}{|l|}{ Metrite Primária } & 0,0001 \\
\hline \multicolumn{4}{|c|}{ Metrite Secundária } \\
\hline \multirow[t]{2}{*}{$(n=13)$} & Desloc. Abomaso vs não & 12,9 & 0,0292 \\
\hline & R. Placenta vs não & 5,88 & 0,0042 \\
\hline $\begin{array}{l}\text { Desloc. Abomasc } \\
(n=09)\end{array}$ & Cetose vs não & 9,45 & 0,0030 \\
\hline
\end{tabular}


No modelo final para hipocalcemia constatou-se que os animais multíparos tiveram 1,48 vezes mais chance de desenvolverem esta enfermidade do que os animais primíparos, que as vacas paridas no inverno tiveram 7,69 vezes mais chance de terem essa doença do que as que pariram no verão, enquanto que as vacas que tiveram retenção de placenta tiveram 4,35 vezes mais chances de serem acometidas por essa mesma enfermidade; tais fatos podem ser explicados por uma maior produção de leite das multíparas e dos animais paridos no inverno e pela retenção de placenta ter entre uma de suas causas a deficiência de contração da musculatura uterina, a qual pode ser relacionada à deficiência de cálcio na circulação sangüínea e musculatura, ocorrência comum nos casos de hipocalcemia (Nebel \& McGilliard, 1993).

O risco da retenção de placenta foi mais freqüente nos animais multíparos (1,33 vezes), quando comparado com animais primíparos. Estes resultados são semelhantes aos citados por Joosten et al. (1987), que indica que a maior ocorrência de retenção de placenta em vacas mais velhas se dá pelo fato desses animais serem mais afetados pelo estresse (ambiental e nutricional), serem sujeitos a gestações mais longas e mais susceptíveis a infecções bacterianas e virais.

O aumento de uma unidade de ECC ao parto (acima de 3,5) aumentou o risco de ocorrência de cetose em 2,04 vezes, resultado similar aos obtidos por Gearhart et al., (1990) e Ruegg \& Milton (1995), sendo explicado pelo fato dos animais supercondicionados (ECC > 4,0) serem mais susceptíveis ao balanço energético negativo após o parto devido à menor ingestão de matéria seca, quando comparados a vacas com ECC adequado (ECC entre 3,0 e 3,5). Quanto mais intenso for o balanço energético negativo, maior será a mobilização de reservas lipídicas, proporcionando maior chance da ocorrência de cetose.

Com relação as vacas com deslocamento de abomaso, a maior chance $(\mathrm{OR}=8,52)$ de desenvolverem um quadro de cetose, é devido a esta patologia ser caracterizada por uma acentuada redução na ingestão de matéria seca, ocasionando o agravamento do balanço energético negativo e forçando o animal utilizar intensamente as reservas corporais lipidicas. 
As vacas multíparas $(\mathrm{OR}=0,51)$ apresentaram menor chance de sofrerem de metrite primária. A correlação esperada entre a metrite secundária (devido à retenção de placenta) e a retenção de placenta foi confirmada com a razão das chances de 5,88.

Os animais portadores de cetose apresentaram 9,45 vezes mais chances de desenvolverem deslocamento de abomaso. Isto é explicado pelo fato de que as vacas com quadro avançado de cetose têm uma acentuada redução no consumo de matéria seca (hipomotilidade ou atonia ruminal), que pode suprimir o trânsito ruminal e aumentar a concentração de ácidos graxos voláteis no líquido ruminal, fatores primários para a ocorrência de deslocamento do abomaso.

Todas estas relações e as respectivas razão das chances podem ser observadas na Figura 1.

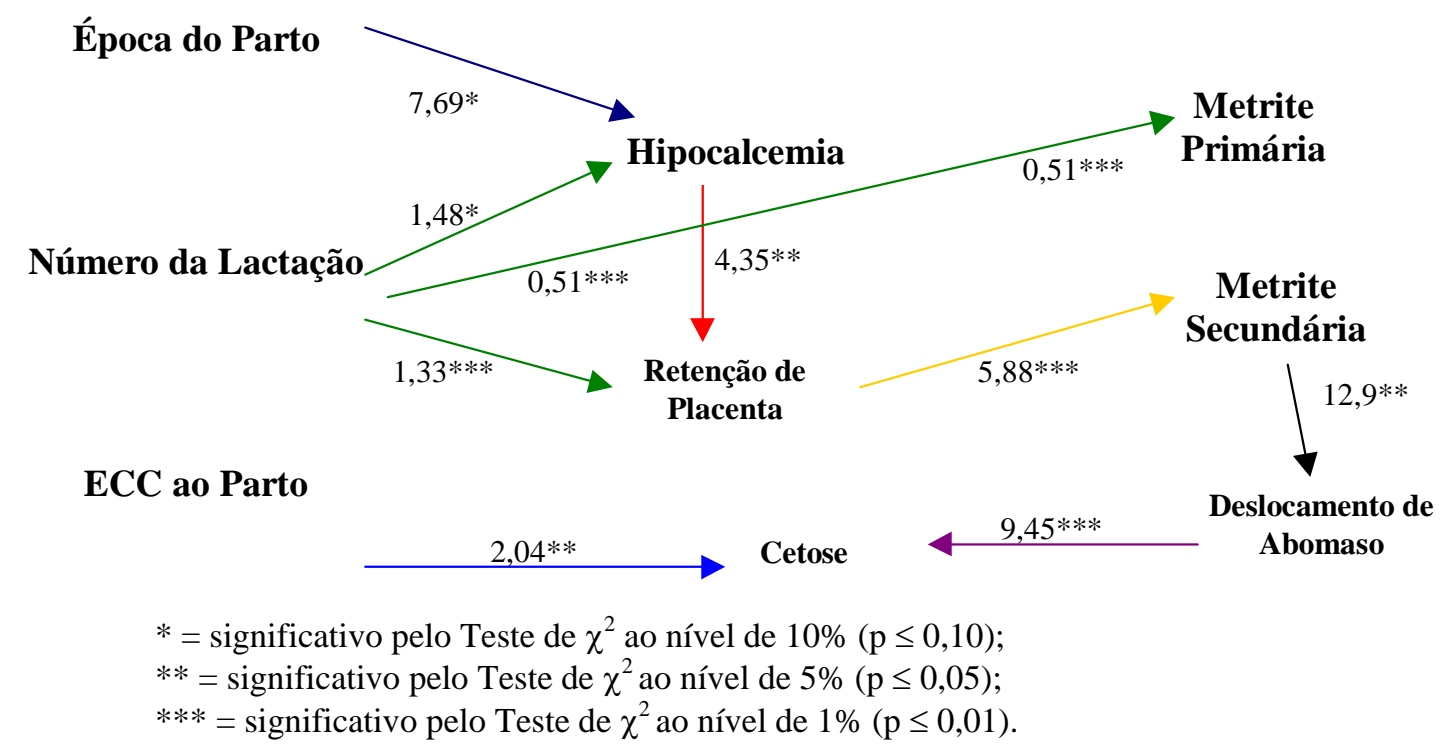

Figura 1 - Relações entre as doenças do periparto e seus fatores de risco em vacas da raça Holandesa de alta produção

Nas figuras 2 e 3 são apresentadas nos gráficos de "box-plot” os valores de produção (em quilos de leite) obtidos para o pico e produção de leite aos 305 dias em lactação, em função do número de lactação (primíparas e multíparas), época do ano ao parto e acometimento ou não por doenças. 


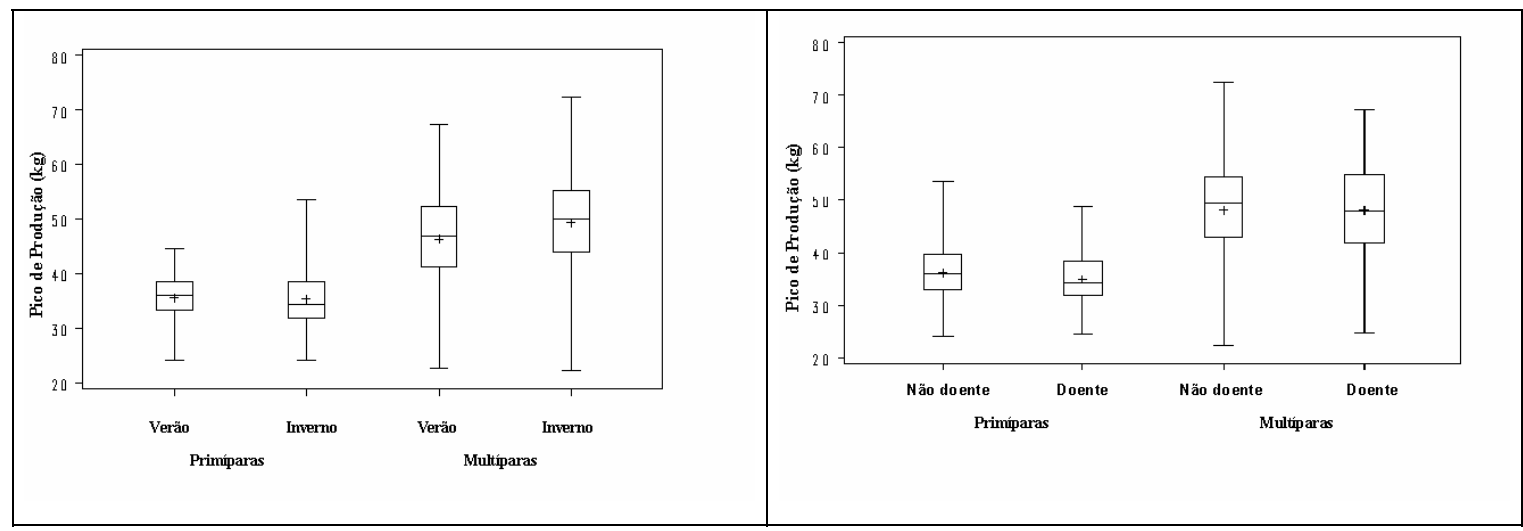

Figura 2 - Box-plot para produção de leite no pico, em função do número de lactações, época do ano ao parto e acometimento ou não por doenças

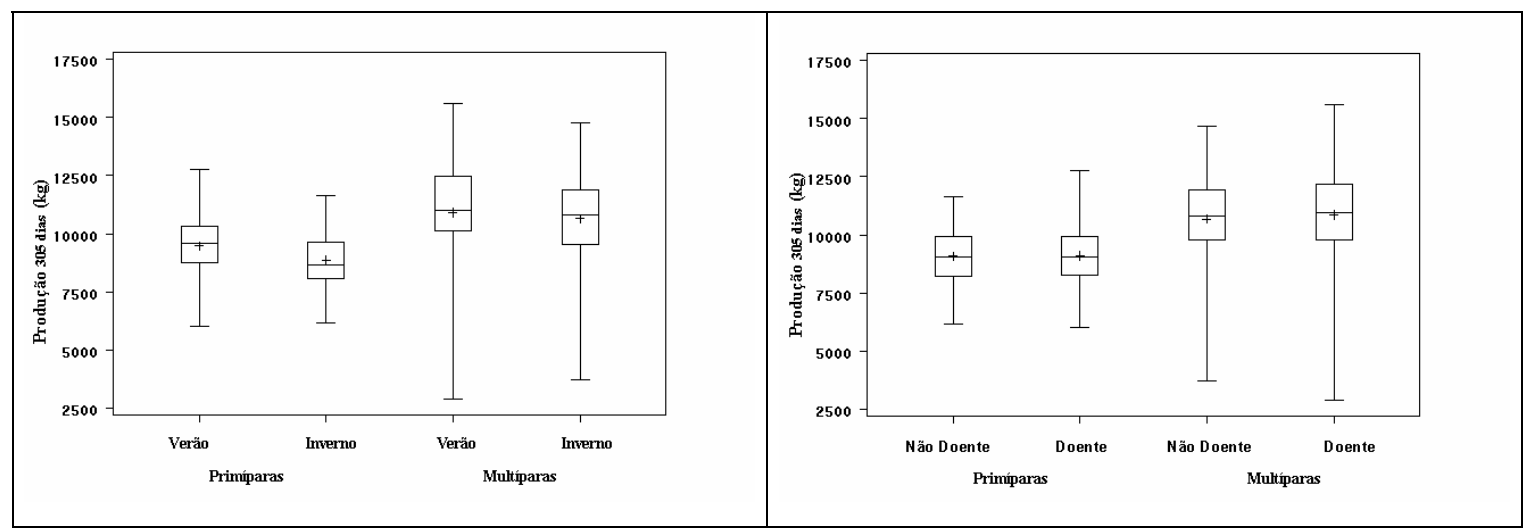

Figura 3 - Box-plot para produção de leite aos 305 dias em lactação, em função do número de lactações, época do ano ao parto e acometimento ou não por doenças

Na terceira parte da análise estatística, utilizando-se a regressão múltipla “stepwise”, foram isolados e quantificados os fatores responsáveis por alterações no pico e na produção de leite aos 305 dias. Nesta análise, os efeitos foram divididos em função do número da lactação dos animais (primíparas e multíparas) devido à presença de heterogeneidade de variâncias, detectada entre vacas primíparas e multíparas, para o pico e a produção de leite aos 305 dias.

Em relação ao pico de produção, as multíparas apresentaram como fator negativo as metrites secundárias, reduzindo o pico em 4,78 $\mathrm{kg}$ de leite $(\mathrm{p}=0,0721)$. Como fatores positivos, foram isoladas as estações do ano ao parto (vacas paridas no 
inverno produziram 3,12 quilos a mais no pico ( $\mathrm{p}=0,0011$ ), quando comparadas a vacas paridas no verão) e o ECC à secagem (o aumento de uma unidade no ECC representou um aumento de 1,44 kg de leite no pico, $\mathrm{p}=0,1050$ ).

As primíparas tiveram o pico afetado apenas de maneira positiva pelo ECC antes do parto, no qual o aumento de uma unidade de ECC à secagem representou $1,45 \mathrm{~kg}$ de leite a mais no pico $(\mathrm{p}=0,0327)$. Estas informações estão disponíveis na Tabela 8.

Tabela 8. Fatores responsáveis por alterações no pico de produção de leite em vacas Holandesas multíparas e primíparas de alta produção

\begin{tabular}{|c|c|c|c|c|}
\hline $\mathrm{NL}^{1}$ & Fatores & $\begin{array}{c}\text { Alterações } \\
\text { Estimadas (Kg) }\end{array}$ & Valor de F & $\mathrm{P}^{2}$ \\
\hline$\tilde{y}$ & Inverno vs Verão & 3,12 & 10,82 & 0,0011 \\
\hline 芛 & $\begin{array}{l}\text { ECC a secagem } \\
\text { (60 dias pré-parto) }\end{array}$ & 1,44 & 2,64 & 0,1050 \\
\hline$\sum$ & Metrite Secundária & $-4,78$ & 3,26 & 0,0721 \\
\hline 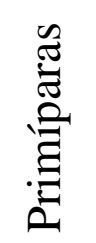 & $\begin{array}{l}\text { ECC a secagem } \\
\text { (60 dias pré-parto) }\end{array}$ & 1,45 & 4,64 & 0,0327 \\
\hline
\end{tabular}

$\mathrm{NL}^{1}=$ Número de lactações.

$\mathrm{p}^{2}=$ nível descritivo de probabilidade pelo teste $\mathrm{F}$.

A produção de leite a 305 dias, para vacas multíparas, somente foi afetada pelo ECC ao parto. O aumento de uma unidade de ECC ao parto representou 466,4 kg de leite a mais por lactação, nas vacas multíparas $(\mathrm{p}=0,0180)$. Este resultado confirma os obtidos por Ruegg \& Milton (1995), de que vacas com maiores reservas corporais, até o limite ideal de 3,75 unidades de ECC produzem mais leite (Tabela 9). 
Tabela 9. Fatores responsáveis por alterações na produção de leite estimada para 305 dias em vacas Holandesas multíparas e primíparas de alta produção

\begin{tabular}{|c|c|c|c|c|}
\hline $\mathrm{NL}^{1}$ & Fatores & $\begin{array}{c}\text { Alterações } \\
\text { Estimadas (kg) }\end{array}$ & Valor de F & $\mathrm{P}^{2}$ \\
\hline 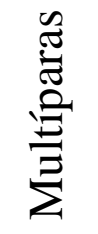 & ECC ao parto & 466,4 & 5,66 & 0,0180 \\
\hline 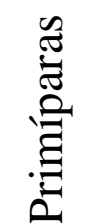 & Inverno vs Verão & $\begin{array}{l}-410,8 \\
-545,9\end{array}$ & 7,08 & 0,0074 \\
\hline
\end{tabular}

$\mathrm{NL}^{1}=$ Número de lactações.

$\mathrm{p}^{2}=$ nível descritivo de probabilidade pelo teste $\mathrm{T}$.

A produção de leite aos 305 dias das primíparas foi afetada pela ocorrência de cetose e devido a estação do ano ao parto. As primíparas que sofreram cetose e as que pariram no inverno, perderam, respectivamente, 410,8 kg e 545,9 kg de leite, ao longo dos 305 dias da lactação, em relação às vacas que não tiveram cetose e as que pariram no verão.

Estes resultados demonstram que as vacas primíparas deste estudo se apresentaram mais susceptíveis às doenças e às alterações climáticas do que as vacas multíparas (Tabela 9); contudo, deve ser ressaltado que a incidência de doenças neste estudo não foi elevada e que os casos foram prontamente tratados, podendo com isto diminuir a gravidade dos problemas. No caso de propriedades com alta incidência de doenças, os animais provavelmente apresentarão um desempenho diferente, podendo ter a produção e o pico afetados de outra maneira.

Em relação à estação do ano ao parto, as primíparas que pariram no verão, quando comparadas às primíparas que pariram no inverno, produziram uma quantidade maior de leite aos 305 DEL, provavelmente devido ao fato que o maior período da 
lactação (cerca de 2/3 da lactação) ocorreu durante a época do inverno (as primíparas possuem uma maior persistência de lactação, melhorada ainda mais pelo uso da somatotropina bovina recombinante).

Quanto à implicação financeira, no caso do rebanho estudado (512 animais em lactação), o prejuízo devido às doenças do periparto (cetose e o fato dos animais parirem no verão) alcançou o valor de R\$ 20.807,66 ao longo da lactação (Tabela 10), calculando-se somente a diminuição na produção de leite, sem incluir os custos de tratamento (medicamentos, veterinário, descarte de leite). Este valor foi calculado a partir do valor médio de R \$ 0,49 (CEPEA, 2003) para o litro de leite pago ao produtor. Esta quantidade de leite perdida representa cerca de 1,2\% de todo leite produzido na fazenda ao longo de 305 dias em lactação, considerando-se que uma propriedade leiteira alcança um lucro máximo de $10 \%$ ao ano, estes fatores (considerando apenas a perda produtiva) estão consumindo grande parte da saúde financeira da atividade.

Tabela 10. Prejuízo calculado na produção de leite, da propriedade estudada, devido às doenças do periparto e seus fatores de risco

\begin{tabular}{|c|c|c|}
\hline \multirow{2}{*}{ Fator de Risco e/ou Doença } & \multicolumn{2}{|c|}{ Prejuízo } \\
\hline & Quilos de leite & $\mathrm{R} \$^{1}$ \\
\hline Cetose (primíparas) & 14.789 & $7.246,61$ \\
\hline Inverno vs. Verão (primíparas) & 46.410 & $22.740,90$ \\
\hline Total ao longo de 305 dias & 61.199 & $29.987,51$ \\
\hline
\end{tabular}

${ }^{1}$ Calculado pelo valor de R\$ 0,49 para o litro de leite pago ao produtor (CEPEA, 2003).

\subsection{Conclusões}

Neste estudo foi possível determinar um modelo complexo da ocorrência das doenças durante o periparto, envolvendo as próprias doenças e outros fatores de risco (nutricionais e ambientais). 
A retenção de placenta e a cetose foram determinadas como fatores de risco para várias desordens. Também foram considerados fatores de risco o número de lactações, a estação do ano ao parto e o escore de condição corporal ao parto, quando incluídos no modelo.

Além disto, os resultados obtidos demonstraram que as doenças do periparto e seus fatores de risco são capazes de afetar significativamente a produção de leite. Contudo, os efeitos tiveram amplitude diferente conforme foram considerados em relação a animais primíparos ou multíparos.

Nas vacas primíparas houve efeito maior das doenças, enquanto que nas multíparas os efeitos maiores foram em relação às alterações do escore de condição corporal e a época do parto.

Não se pode esquecer, contudo, que os dados utilizados neste estudo foram coletados em uma única e bem operada propriedade leiteira, com alta produção de leite (Média de Equivalente Adulto $9.982 \mathrm{~kg}$ ), e uso intensivo de programas de prevenção e diagnóstico de doenças. Assim, a confirmação destes resultados em outros rebanhos de menor produção é necessária, antes de serem generalizados para situações diversas.

Estes resultados demonstram também que há necessidade de maior cuidado com as medidas profiláticas para se evitar as doenças, e que seja mantida especial atenção ao manejo nutricional, monitorado através do ECC, e ao controle ambiental, para que se maximize a produção de leite e a sanidade dos animais. 


\section{DETERMINAÇÃO DE FATORES DE RISCO ASSOCIADOS A FALHAS DE CONCEPÇÃO AO PRIMEIRO SERVIÇO EM VACAS LEITEIRAS DE ALTA PRODUÇÃO}

Resumo

Este estudo investigou fatores potenciais de riscos para falhas na concepção ao primeiro serviço pós-parto (CPS). Vacas holandesas $(n=427)$ de um rebanho comercial do Estado de São Paulo tiveram seu desempenho reprodutivo, sanitário e nutricional acompanhados desde o início do período pré-parto até o diagnóstico de gestação ao primeiro serviço. A ocorrência de doenças e os escores de condição corporal (ECC), no pré e pós parto, e as produções e composições do leite, no pós-parto, foram registradas. Análises de regressão logística, calculando-se a razão das chances, foram utilizadas no isolamento dos fatores de risco, e na associação entre os diversos riscos para sucesso ou falha na CPS. As principais variáveis ordenadas foram o número da lactação, a época do ano ao primeiro serviço, a relação entre as porcentagens de gordura e proteína do leite (RGP) e a produção de leite na época do $1^{\circ}$ serviço, dias em lactação ao $1^{\circ}$ serviço e as alterações no ECC. Os animais de primeira lactação apresentaram maior chance de sucesso ao primeiro serviço do que os animais multíparos. As vacas cobertas no período do inverno apresentaram, aproximadamente, cinco vezes mais chances de CPS do que as vacas cobertas no verão. Animais que apresentaram desordens sanitárias no periparto e baixo ECC ao parto tiveram menor sucesso de concepção que os animais sadios. Os animais que apresentaram melhor 
condição ruminal, determinada pela RGP, e maior produção de leite, durante o período de verão, tiveram uma melhor concepção do que os animais com RGP reduzida e menores produções no verão. O ECC, adequado nas diferentes fases produtivas das vacas (secagem, parto e cobertura), demonstrou ser uma importante ferramenta para identificar vacas com risco de insucesso na concepção ao primeiro serviço.

Palavras chave: reprodução, componentes do leite, escore de condição corporal, vacas leiteiras, concepção ao primeiro serviço.

\section{Determination of health factors associated with first conception service failures affecting milk productivity on lactating dairy cows}

Summary

This study evaluated potential factors that would increase the risks for failure on the first post partum service (CFS). Data were collected from a commercial herd of holstein cows $(n=427)$ of the São Paulo State, recording nutritional and health performance scores like, diseases, body condition, milk daily production and composition from pre calving to the first service conception check. Data recorded were processed through logistic regression analysis, in order to define the success or failure at first conception service, calculating odds ratio with isolated and association of several risk factors. Variables like number of lactation, first service season, peripartum diseases event, body condition scores (BCS) changes, milk fat and protein ratio (FPR). First lactation animals showed better chances of success on first service than multiparous animals. Cows inseminated during the winter showed five times more chance of CFS occurrence than the ones inseminated in during summer time. Health cows had a better conception performance than the ones with peripartum diseases, animals with better ruminal condition (FPR) mainly at summer time, presented better conception than ones with lower FPR. The BCS correctly applied to the animal on different steps of life, dry 
off, insemination and first service demonstrated to be an important tool on identifying cows with higher risk for failure of conception at first service.

Key Words: reproduction, milk components, body condition score; dairy cows, first conception service.

\subsection{Introdução}

A reprodução, dentro da pecuária leiteira, ocupa papel de destaque, sendo um dos fatores de maior contribuição para a viabilidade econômica da atividade como um todo (Martin, 1992).

Atualmente, grande número de trabalhos publicados tem estudado o declínio da eficiência reprodutiva dos bovinos leiteiros. Butler (1998) ao estudar rebanhos leiteiros de Nova York (EUA) apresentou dados que evidenciam um declínio na taxa de concepção à primeira cobertura, de 65\% em 1951 para 40\% em 1996. Lucy (2001), ao revisar trabalhos publicados no Journal of Dairy Science, confirmou esse declínio. Em 1950, os pesquisadores reportavam taxas de concepção de aproximadamente 55\% (Casida, 1961); já os trabalhos publicados recentemente reportam taxas de aproximadamente $45 \%$ de concepção em estros espontâneos (Dransfield et al., 1998) e de aproximadamente 35\% em inseminações em tempo fixo (Schmitt et al., 1996 e Pursley et al., 1998). Essa menor eficiência reprodutiva foi citada em trabalhos feitos no mundo inteiro (Roche, 2000; Royal et al., 2000 e Macmilan et al., 1996), sendo sugerido que a redução na fertilidade é relacionada ao aumento da produção leiteira.

Sendo assim, evidencia-se a necessidade de estudos que possam verificar se o mesmo ocorre nos rebanhos brasileiros, e identificar possíveis causas da redução no desempenho reprodutivo, determinando fatores que possam contribuir para a infertilidade dos animais. Interessam ao pesquisador eventos de natureza fisiológica, 
patológica, terapêutica, ambiental e de manejo, os quais podem ou não interagir, influenciando o desempenho reprodutivo das vacas.

A análise de parâmetros tais como intervalo entre partos, taxa de detecção de cio, dias do parto ao primeiro serviço, taxa de concepção, doses de sêmen por concepção e intervalo de cios podem auxiliar muito na avaliação da fertilidade do rebanho.

Analisando estes parâmetros, De Kruif (1993) destaca que a fertilidade de um rebanho deve ser avaliada baseando-se em três critérios principais: a taxa de concepção à primeira cobertura; o número de serviços necessários por concepção e o intervalo do parto à concepção. Contudo, utilizando-se a avaliação da taxa de concepção à $1^{\text {a }}$ cobertura serão avaliados todos os animais liberados após o período voluntário de espera, durante a fase de lactação onde os animais encontram-se com acentuado balanço energético negativo. $\mathrm{O}$ parâmetro referente exclusivamente ao intervalo do parto à concepção, pode ser muito variável nas diversas propriedades, devido ao uso de diferentes períodos voluntários de espera, dificultando assim a comparação entre rebanhos e estudos.

Para se atingir a máxima eficiência reprodutiva é importante que as vacas retornem à função reprodutiva o mais rápido possível. Segundo Erb \& Smith (1987), os principais fatores que afetam a retomada da função reprodutiva no pós-parto estão ligados à vaca (alta produção de leite no início da lactação, época do parto, peso corpóreo, escore de condição corporal, raça, idade e número de lactações), ao bezerro (tamanho, sexo, mortalidade fetal e incidência de partos gemelares), problemas do periparto (distocias, hipocalcemia, prolapsos de útero ou vagina, retenção de placenta, metrite, cetose, deslocamento de abomaso) e, ainda, mastites, laminites e outras conseqüências da alta produção leiteira.

Conforme afirmações de Call \& Stevenson (1985) e Erb \& Grohn (1988), pode-se concluir que o período do periparto é o momento chave, extremamente importante, para otimizar-se a reprodução de vacas leiteiras, pois é um momento em que há sobreposição de eventos potencialmente conflitantes e antagônicos, tais como a demanda energética máxima para o início da lactação e a necessidade da retomada da 
atividade cíclica ovariana (Markusfeld, 1990 e Peters, 1996), devendo ainda ser considerado o risco de ocorrência de fatores negativos, tais como, infecções do trato reprodutivo (Hussain, 1989) e doenças metabólicas (Lean et al., 1992), comuns no pósparto.

O objetivo deste estudo foi investigar fatores potenciais de riscos para falhas na concepção ao primeiro serviço pós-parto (CPS) em vacas com altas produções de leite.

\subsection{Material e Métodos}

\subsubsection{Seleção de animais}

Este estudo foi desenvolvido em uma fazenda comercial (com 600 animais em lactação), localizada no município de Araras, no Estado de São Paulo, região de clima subtropical, com temperatura máxima de $35{ }^{\circ} \mathrm{C}$ em dezembro, janeiro e fevereiro e mínima de $10{ }^{\circ} \mathrm{C}$ em maio, junho e julho. As vacas estiveram confinadas em “free-stalls” dotados de ventiladores e aspersores, acionados automaticamente quando a temperatura ambiente ultrapassava os $23^{\circ} \mathrm{C}$. A produção de leite em equivalente adulto calculada do rebanho foi de aproximadamente $10.000 \mathrm{~kg}$. As vacas em lactação foram divididas em oito grupos baseados na produção e número de lactação. As vacas primíparas foram mantidas no mesmo grupo durante toda a lactação.

As vacas multíparas entraram no estudo no momento da secagem. Todas as vacas secas durante os meses de novembro de 2000 e novembro de 2001 foram incluídas no estudo. Todas a novilhas que tiveram o primeiro parto previsto entre novembro de 2000 e novembro de 2001 entraram no estudo 60 dias antes da data prevista para o parto. A coleta de dados foi concluída quando as vacas atingiram 150 dias em lactação ou no primeiro serviço, quando este foi inferior aos 150 dias em lactação. As vacas descartadas ou mortas antes dos 150 dias de lactação não tiveram seus dados analisados. 


\subsubsection{Alimentação e monitoramento nutricional}

Os animais foram alimentados sete vezes ao dia, ocorrendo o primeiro fornecimento às 5:00 horas e o último às 21:00 horas. A dieta foi do tipo total e única para todos animais, composta com os ingredientes citados na Tabela 1 e com composição bromatológica citada na Tabela 2.

Tabela 1. Composição da dieta das vacas em lactação por ingredientes em \% da matéria seca

\begin{tabular}{lc}
\hline \multicolumn{1}{c}{ Ingrediente } & $\% \mathrm{MS}$ \\
\hline Silagem de milho & 36,60 \\
Pré-secado de “Coast Cross” & 9,00 \\
Polpa cítrica peletizada & 11,18 \\
Gérmen de milho & 13,40 \\
Farelo de soja & 11,98 \\
Protenose de milho & 2,22 \\
Silagem de grão de milho com alta umidade & 12,51 \\
Concentrado mineral e vitamínico* & 2,22 \\
Sais de sabões de cálcio (gordura protegida) & 0,89 \\
\hline
\end{tabular}

*Composição: Ca 17,69 \%; Pt 3,33 \%; Mg 4,60 \%; Na 8,67 \%; K 3,58 \%; Cl 10,22 \%; S 1,43\%; Vit. A (1000 UI/kg) 221,28; Vit. D3 (1000 UI/kg) 34,23; Vit. E (UI/kg) 885,12; Fe (mg/kg) 1.545,42; Cu $(\mathrm{mg} / \mathrm{kg})$ 715,21; Mn (mg/kg) 1.442,12; Zn (mg/kg) 2.314,37; Co (mg/kg) 5,21; I (mg/kg) 21,02; Se (mg/kg) 10,46; Fl (mg/kg) 333,50; monesina (mg/kg) 352,80.

Tabela 2. Composição bromatológica média da dieta das vacas em lactação, durante o período experimental (em \% matéria seca)

\begin{tabular}{lc}
\hline \multicolumn{1}{c}{ Nutriente } & \% Matéria Seca \\
\hline Matéria seca (\%) & 51,2 \\
Proteína bruta & 15,9 \\
Extrato etéreo & 3,8 \\
Fibra em detergente ácido & 21,4 \\
Fibra em detergente neutro & 36,8 \\
Carboidratos não estruturais & 37,7 \\
Matéria mineral & 5,9 \\
\hline
\end{tabular}


As dietas foram formuladas seguindo as recomendações do NRC Dairy Cattle (NRC, 2001), sendo calculadas e avaliadas com auxílio do software Spartan Ration Evaluator - Balancer, versão 2.0, 1992 (MSU, 1992). Durante o período do estudo os ingredientes utilizados na dieta foram substituídos conforme a disponibilidade de mercado e flutuação de preços.

Para a coleta de amostras representativas da dieta, na extensão do cocho foram estendidas três lonas plásticas (início, meio e final do cocho) de dimensões de 1,5m x 1,0m, antes da distribuição dos alimentos aos animais. Após a passagem do vagão distribuidor de ração, as amostras de cada uma das lonas plásticas foram misturadas e homogeneizadas, sendo retirada deste volume uma amostra da dieta, que foi mantida armazenada em câmara fria até o momento da análise laboratorial. Através das análises bromatológicas, realizadas mensalmente, foram determinados os teores de proteína bruta, extrato etéreo, matéria seca, matéria mineral, fibra detergente neutro e fibra detergente ácido, segundo a metodologia proposta por Goering e Van Soest (1970), no laboratório de análises bromatológicas da FMVZ-USP.

O acompanhamento da nutrição dos animais foi realizado através da avaliação do consumo de matéria seca (CMS) e do controle do tamanho de partículas da dieta. O consumo de matéria seca foi obtido através das pesagens diárias, da dieta fornecida e das sobras de cocho de cada lote. Com estes dados foram calculados os consumos diários por animal. O valor do consumo de matéria seca usado neste estudo foi a média dos consumos diários de cada mês.

O tamanho de partículas da dieta foi avaliado através dos Separadores de Partículas da Universidade da Pensilvânia, seguindo a metodologia do mesmo (Lammers et al., 1996). As partículas foram determinadas como a porção retida na peneira superior (grossa - 19mm), na peneira média (média - 8mm) e o restante da amostra (fina), sendo expressos em porcentagens do total. Essa avaliação foi feita mensalmente, nos mesmos dias das coletas de amostras da dieta para as análises bromatológicas.

A Tabela 3 apresenta a análise descritiva (relativa a 12 amostragens anuais) das variáveis relacionadas aos consumos de matéria seca (CMS) e aos tamanhos das partículas. 
Tabela 3. Análise descritiva das variáveis relacionadas aos consumos de matéria seca e aos tamanhos de partículas

\begin{tabular}{|c|c|c|c|c|c|c|}
\hline & Variáveis & Média & D. Padrão & C. V. (\%) & Mínimo & Máximo \\
\hline 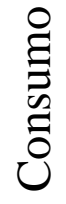 & $\begin{array}{c}\text { Matéria Seca } \\
\text { (kg/dia) }\end{array}$ & 21,75 & 2,29 & 10,54 & 17,11 & 24,32 \\
\hline \multirow{3}{*}{ 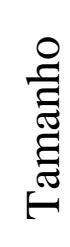 } & Grossa (\%) & 25,13 & 3,15 & 12,52 & 21,99 & 32,28 \\
\hline & Media (\%) & 34,50 & 1,85 & 5,37 & 32,71 & 38,02 \\
\hline & Fina (\%) & 40,37 & 4,66 & 11,54 & 29,70 & 45,23 \\
\hline
\end{tabular}

Os valores médios obtidos para o CMS e para o tamanho de partículas são semelhantes aos valores médios encontrados na literatura e considerados normais para vacas da raça Holandesa criadas em regime intensivo (Heinrichs et al., 1999; Hettinga, 1989 e Linn, 1991).

\subsubsection{Coleta de dados experimentais}

Foram coletados 13.594 dados zootécnicos e sanitários referentes à concepção à primeira cobertura ocorrida após 60 dias em lactação (confirmada 40 a 45 dias após a $1^{\mathrm{a}}$ inseminação artificial, por palpação retal), produção e composição de leite na primeira cobertura (uréia, gordura, proteína), época do ano em relação à parição e à cobertura, escore de condição corporal à secagem, ao parto e à $1^{\text {a }}$ cobertura, além de doenças ao periparto (hipocalcemia, retenção de placenta, metrites primária e secundária, cetose e deslocamento de abomaso). 


\subsubsection{Produção e composição do leite}

As vacas foram ordenhadas três vezes ao dia, em sala de ordenha informatizada. As produções diárias de leite de cada vaca foram medidas e registradas eletronicamente via computadores. A partir destes dados foi calculada a produção de leite ao primeiro serviço (média de produção calculada com dados de produção leiteira dos 5 dias anteriores e 5 dias posteriores a cobertura).

Foram coletadas mensalmente amostras de leite, segundo as recomendações do IDF Standards (1996), sempre na ordenha da manhã, diretamente do copo medidor, sendo transferidas para os frascos de coleta (contendo o conservante bronopol), e encaminhadas ao Laboratório da Clínica do Leite (ESALQ/USP), para determinação dos teores de gordura, proteína e uréia.

As concentrações de gordura e proteína foram determinadas por leitura de absorção infravermelha, e as concentrações de nitrogênio uréico no leite determinadas através de um método enzimático e espectrofotométrico de trans-reflectância.

\subsubsection{Desordens sanitárias}

Todas as doenças foram diagnosticadas e registradas por um veterinário, sendo estes dados coletados em visitas diárias à fazenda. As doenças foram codificadas como ocorridas ou não ocorridas ( 0 =não e $1=\operatorname{sim})$. Ocorrências repetidas ou de um mesmo diagnóstico, em uma mesma vaca não foram registradas, desta forma, o cálculo das incidências das doenças levou em consideração apenas a primeira ocorrência de cada doença. As doenças de interesse para o estudo foram: hipocalcemia, cetose clínica, deslocamento de abomaso, retenção de placenta e metrites primárias ou secundárias. As definiç̧ões das desordens sanitárias são demonstradas na tabela 4 e são semelhantes às utilizadas em outros estudos. 
Tabela 4. Definições das desordens sanitárias avaliadas

\begin{tabular}{|c|c|}
\hline Desordem & Definição \\
\hline Hipocalcemia & $\begin{array}{l}\text { Fraqueza, baixa temperatura e resposta favorável a terapia } \\
\text { endovenosa com cálcio. }\end{array}$ \\
\hline Retenção de Placenta & Retenção das membranas fetais > 18 h após o parto. \\
\hline Cetose Subclínica & $\begin{array}{l}\text { Determinação da presença de corpos cetônicos na urina } \\
\text { com auxílio de fita reagente (Ketostic - Bayer }{ }^{\circledR} \text { ). }\end{array}$ \\
\hline Metrite Primária & $\begin{array}{l}\text { Descarga abundante e útero com tamanho anormal } \\
\text { durante a palpação transrectal, diagnosticada no primeiro } \\
\text { mês de lactação. }\end{array}$ \\
\hline Metrite Secundária & Metrite diagnosticada após caso de retenção de placenta. \\
\hline Deslocamento de Abomaso & $\begin{array}{l}\text { Som metálico durante a auscultação abdominal e correção } \\
\text { cirúrgica. }\end{array}$ \\
\hline
\end{tabular}

\subsubsection{Escore de condição corporal}

Toda avaliação de escore de condição corporal (ECC) foi feita por um único indivíduo, segundo a metodologia visual descrita por Wildman et al., (1982). As avaliações foram feitas no momento da entrada dos animais no estudo, ao parto e no momento da cobertura.

A medida do ECC no momento da entrada dos animais no experimento (ECC à secagem), foi feita no dia em que os animais foram transferidos para o lote préparto. Desta forma, tanto os animais multíparos (que foram tratados com antibiótico intramamário no processo de secagem, sessenta dias antes do parto), como os primíparos (transferidos para o lote pré-parto 60 dias antes da data prevista do parto), tiveram o escore de condição, determinado como ECC à secagem avaliado desta maneira. As medidas do ECC ao parto, foram realizadas no dia após o parto, no momento do exame clínico do animal. Já a medida do ECC à cobertura foi realizada no dia da realização do primeiro serviço. 


\subsubsection{Análise estatística}

As análises estatísticas descritivas e a modelagem foram realizadas utilizando-se o sistema de análises estatísticas SAS (1999). Para a determinação dos fatores de risco para concepção à primeira inseminação, foram realizadas análises de regressão logística múltipla, utilizando-se, para tal, o procedimento LOGISTIC do SAS (1999), calculando-se a razão das chances, também denominada de odds ratio.

A razão de chance (ou odds ratio) é uma medida da força de associação entre variáveis independentes e dependentes, que são extensivamente usados em estudos epidemiológicos (Erb et al., 1985 e Gearhart et al., 1990). O odds ratio (OR) é o "log” natural do parâmetro estimado obtido na análise de regressão logística. Um odds ratio de 1,0 sugere que não existe alguma associação entre as variáveis dependentes e independentes; valores maiores ou menores que 1,0 indicam associação positiva ou negativa entre as variáveis, respectivamente (Domecq et al., 1997). Neste estudo, o modelo de regressão logística múltipla foi utilizado devido as variáveis serem dependentes discretas.

\subsection{Resultados e Discussão}

Neste estudo foi incluído um total de 427 animais. A taxa de concepção ao $1^{\circ}$ serviço (CPS) para o rebanho foi de 33,5 \%. As 163 vacas primíparas obtiveram uma taxa de CPS de 40,9\% e as 264 vacas multíparas obtiveram a taxa de CPS de 26,1\%. Foi observada uma concentração de partos e de coberturas no inverno (respectivamente 58,3\% e 79,9\%). Dos animais avaliados, 61,8\% eram multíparos e 50,1\% não tiveram nenhuma doença durante o período do periparto. A média anual de produção de leite foi superior a $10.000 \mathrm{~kg}$ por vaca. 
Na Tabela 5 estão apresentadas as freqüências e porcentagens e das variáveis qualitativas avaliadas.

Tabela 5. Estatística descritiva para as variáveis qualitativas estudadas como fatores de risco para concepção ao primeiro serviço de vacas leiteiras

\begin{tabular}{|c|c|c|}
\hline Fatores & Freqüência & $\%$ \\
\hline \multicolumn{3}{|l|}{ Número da Lactação } \\
\hline Primíparas & 163 & 38,2 \\
\hline Multíparas & 264 & 61,8 \\
\hline \multicolumn{3}{|l|}{ Época do Parto } \\
\hline Verão & 178 & 41,7 \\
\hline Inverno & 249 & 58,3 \\
\hline \multicolumn{3}{|l|}{ Época de Cobertura } \\
\hline Verão & 86 & 20,1 \\
\hline Inverno & 341 & 79,9 \\
\hline \multicolumn{3}{|l|}{ Doenças } \\
\hline Não & 214 & 50,1 \\
\hline Sim & 213 & 49,9 \\
\hline \multicolumn{3}{|c|}{ Concepção ao $1^{\circ}$ serviço (CPS) } \\
\hline Não & 284 & 66,5 \\
\hline Sim & 143 & 33,5 \\
\hline
\end{tabular}

Na Tabela 6, podem ser observadas individualmente as incidências de cada uma das doenças avaliadas no estudo. A incidência de doenças deste estudo está de acordo com as apresentadas em outros estudos (Domecq et al., 1997; Erb \& Grohn, 1988; Gearhart, 1990; Markusfeld, 1990 e Risco, 1992), feitos com rebanhos de mesmo nível produtivo e características de manejo semelhantes. No presente estudo, a metrite foi a doença de maior incidência no rebanho (19,5\%).

Devido ao reduzido número de ocorrência de casos de algumas doenças (por exemplo: hipocalcemia e deslocamento de abomaso), pelo fato dos casos apresentarem 
diferentes graus de severidade e também devido à associação entre as desordens, foi decidido avaliar as doenças em um único conjunto. Assim, na avaliação das doenças foram consideradas apenas duas classes de animais: os doentes e os não doentes.

Tabela 6. Incidência de desordens sanitárias avaliadas como fatores de risco para concepção ao primeiro serviço de vacas leiteiras

\begin{tabular}{lc}
\hline \multicolumn{1}{c}{ Desordem } & Incidência (\%) \\
\hline Hipocalcemia & 1,8 \\
Retenção de Placenta & 16,1 \\
Cetose & 17,5 \\
Metrite Primária & 18,1 \\
Metrite Secundária & 2,6 \\
Deslocamento de Abomaso & 1,8 \\
\hline
\end{tabular}

Na Tabela 7 são descritas as médias, os coeficientes de variação, os desvios padrão e os valores mínimos e máximos de todas estas variáveis quantitativas avaliadas no estudo.

Tabela 7. Estatística descritiva das variáveis quantitativas estudadas como fatores de risco para concepção ao primeiro serviço de vacas leiteiras

\begin{tabular}{lccccc}
\hline \multicolumn{1}{c}{ Fatores } & Média & D. Padrão & C.V. (\%) & Mínimo & Máximo \\
\hline Produção leite no pico (kg) & 43,25 & 9,80 & 22,66 & 22,20 & 72,40 \\
DEL até o pico & 61,15 & 10,72 & 17,54 & 45 & 90 \\
Produção ao 1 ${ }^{\circ}$ serviço $(\mathrm{kg})$ & 38,91 & 9,06 & 23,28 & 17,00 & 63,40 \\
DEL até o 1 ${ }^{\circ}$ serviço & 82,32 & 19,50 & 23,68 & 60 & 150 \\
Gordura (\%) & 2,94 & 0,72 & 24,36 & 1,21 & 6,52 \\
Proteína (\%) & 2,82 & 0,25 & 8,78 & 2,24 & 3,97 \\
Relação Gordura/Proteína & 1,05 & 0,28 & 26,80 & 0,42 & 2,80 \\
MUN (mg/dL) & 12,90 & 3,17 & 24,57 & 2,60 & 21,68 \\
ECC ao parto & 3,57 & 0,51 & 14,35 & 2,30 & 5,00 \\
ECC à cobertura & 3,28 & 0,53 & 16,03 & 2,00 & 4,80 \\
ECC à secagem & 3,53 & 0,65 & 18,43 & 2,20 & 5,00 \\
\hline * DEL = Dias em lactação, MUN = Nitrogênio ureíco no leite, ECC = Escore de condição corporal
\end{tabular}


A média geral de produção de leite diária do rebanho foi igual a 38,91 kg, produção esta considerada alta quando comparada com a média de 22,62 kg para rebanhos brasileiros da raça holandesa (Machado, 2003). O número médio de dias em lactação (DEL) até o pico foi de 61,15, sendo que o primeiro serviço foi realizado após o pico (a média de DEL até o primeiro serviço foi de 82,32).

As concentrações médias de nitrogênio ureíco no leite (MUN), gordura (G) e proteína (P) no mês da cobertura foram de 12,9 mg/dL, 2,94\% e 2,82\%, respectivamente, e a relação gordura/ proteína (RGP) média foi de 1,05.

O valor médio de MUN (12,9 mg/dL) obtido neste estudo está abaixo do considerado crítico para reprodução segundo vários autores (Kaim et al., 1983; Bruckental et al., 1989; Canfield et al., 1990; Larson et al., 1997 e Melendez et al., 2000). Eles verificaram que a diminuição significativa da taxa de concepção das vacas somente ocorreu quando os valores médios de MUN foram superiores a 15,4 mg/dL. Entretanto, Rajala-Schultz et al. (2001), afirmaram ser possível o decréscimo na capacidade reprodutiva, mesmo com valores inferiores a estes $(15,4 \mathrm{mg} / \mathrm{dL})$, em situações específicas, como condições de estresse térmico. No presente estudo não foi determinado o efeito negativo do MUN sobre a reprodução dos animais, provavelmente porque a média obtida $(12,9 \mathrm{mg} / \mathrm{dl})$ está dentro da faixa considerada ideal (10 a 14 $\mathrm{mg} / \mathrm{dl})$.

As concentrações médias de gordura (2,94\%) e proteína (2,82\%) obtidas no estudo próximo ao momento da inseminação artificial, apesar de serem baixas em relação a vários trabalhos, também estão dentro dos padrões citados na literatura (2,2 a 4,0\% para gordura e 2,8 a 3,6\% para proteína) (Fonseca \& Santos, 2000 e Sutton, 1989). A relação entre gordura e proteína do estudo $(1,05)$ também está de acordo com a literatura, que indica valores entre 1,0 e 1,1 como ideais (Carvalho, 2000, Hutjens, 2001 e Loeffler et al., 1999).

Possivelmente devido aos valores médios de G e P estarem dentro dos padrões considerados como normais pela literatura, não foi possível correlacionar diretamente estes componentes do leite com a reprodução. 
As médias obtidas de ECC ao parto, à cobertura e à secagem foram, aproximadamente, 3,6, 3,3 e 3,5 unidades. Estes valores médios indicam que tais valores se encontravam dentro das metas sugeridas na literatura (Fergunson, 1992), para o ECC ao parto $(3,5), \quad$ cobertura $(3,0)$ e período seco $(3,5)$. Dentre todas as variáveis estudadas, apenas os fatores significativos a 0,20 e as interações entre elas foram avaliadas para o modelo final. Com este procedimento, foram excluídas as seguintes variáveis: época do parto, concentrações de MUN e teores de gordura e proteína do leite. Foram mantidas outras variáveis: o número da lactação, a época da cobertura, o estado sanitário, a produção de leite ao $1^{\circ}$ serviço, os dias em lactação até o $1^{\circ}$ serviço, os ECC ao parto, secagem e cobertura e a relação gordura/proteína do leite. O modelo final da regressão logística para os fatores de risco de concepção pode ser observado na Tabela 8. 
Tabela 8. Odds ratio, intervalos de confiança a $90 \%$ e nível descritivo de probabilidade para a regressão logística, para os fatores de risco de para concepção de vacas leiteiras no primeiro serviço.

\begin{tabular}{|c|c|c|}
\hline Fatores & Odds Ratio & $\mathrm{P}^{1}$ \\
\hline \multicolumn{3}{|l|}{ Número da lactação } \\
\hline 1 & 1,000 & \\
\hline$\geq 2$ & 0,453 & 0,0087 \\
\hline \multicolumn{3}{|l|}{ Época do $1^{\circ}$ serviço } \\
\hline Verão & 1,000 & \\
\hline Inverno & 14,94 & 0,0081 \\
\hline \multicolumn{3}{|c|}{$\begin{array}{l}\text { Relação gordura / proteína do leite na época do } \\
1^{\circ} \text { serviço }\end{array}$} \\
\hline Verão & 6,378 & 0,0714 \\
\hline Inverno & 0,745 & 0,4995 \\
\hline \multicolumn{3}{|c|}{$\begin{array}{l}\text { Produção de leite ao } 1^{\circ} \text { serviço na época do } 1^{\circ} \\
\text { serviço }\end{array}$} \\
\hline Verão & 1,057 & 0,1553 \\
\hline Inverno & 1,001 & 0,9429 \\
\hline Dias em lactação até o $1^{\circ}$ serviço & 0,989 & 0,0670 \\
\hline \multicolumn{3}{|l|}{ ECC ao parto dentro da doença } \\
\hline Doente & 1,750 & 0,1427 \\
\hline Não doente & 0,912 & 0,7986 \\
\hline ECC no momento da secagem & 0,734 & 0,1414 \\
\hline ECC no momento da cobertura & 1,562 & 0,0523 \\
\hline
\end{tabular}

${ }^{1} p=$ nível descritivo de probabilidade pelo Teste de Wald.

Neste modelo pode-se observar que as vacas multíparas possuem índice de concepção inferior ao das vacas primíparas $(\mathrm{OR}=0,453)$, ao nível descritivo de probabilidade pelo Teste de Wald de $\mathrm{p} \leq 0,0087$, estando este resultado de acordo com os obtidos no estudo de Miettinem \& Setala, (1993). Vários pesquisadores justificaram este resultado, argumentando que vacas com maiores produções de leite são menos férteis 
que vacas com menores produções (Eicker et al., 1996; Farin et al., 1994; Grohn et al., 1986 e Nebel \& McGilliard, 1993). Deve-se salientar, no entanto, como um aspecto até mais importante do que este, que as vacas adultas, com maior produção, produzem maior calor metabólico, sendo mais afetadas pelo estresse térmico do ambiente, fato este confirmado pela avaliação da época do ano ao primeiro serviço.

A época do ano em que foi realizada a cobertura afetou bastante a concepção ao $1^{\circ}$ serviço. Neste rebanho, as vacas que receberam o primeiro serviço pósparto no inverno tiveram aproximadamente quinze vezes mais chances de sucesso de CPS (OR = 14,94; $\mathrm{p} \leq$ 0,0081), do que as vacas cobertas no verão. Este resultado sugere que o ambiente exerce um grande efeito sobre o metabolismo reprodutivo do animal. Segundo Hansen (2000) e Wolfenson et al. (2000), as vacas da raça holandesa em lactação são extremamente sensíveis ao estresse térmico, devido à alta taxa metabólica associada à lactação.

Os efeitos do estresse térmico sobre a reprodução são vários; eles exercem efeitos deletérios sobre os embriões, reduzindo drasticamente as taxas de sobrevida, reduzindo a produção de estrógeno pelo folículo pré-ovulatório e afetando a qualidade do ovócito e do espermatozóide. Podem ainda afetar altamente a manifestação do cio pelas vacas, dificultando assim a visualização dos animais em cio para execução da inseminação artificial.

Os resultados obtidos no presente estudo relativos à época de cobertura refletem os obtidos em vários estudos (Seykora et al. 1983; Chenoweth \& Larsen 1992; Faust et al. 1988; Farin et al. 1994; Hansen et al. 1992 e Silva et al. 1992), nos quais a concepção foi afetada pela época do ano da cobertura.

Na avaliação da relação entre gordura e proteína do leite (RGP), dentro da época de cobertura (inverno e verão), foi detectado que a cada aumento na RGP durante o verão, os animais tiveram, aproximadamente, seis vezes ( $O R=6,378, p \leq 0,0714)$ mais chances de concepção à $1^{\text {a }}$ cobertura do que os animais que tiveram a RGP reduzida no verão. Contudo, na época do inverno não foi isolada a influência da RGP sobre a fertilidade ( $\mathrm{p} \leq$. 0,4995). Esta constatação pode indicar que os animais com melhor 
condição ruminal (e possivelmente com maior produção de leite) podem apresentar concepção melhor sob condições de estresse térmico.

A hipótese anterior pode ser confirmada com os resultados relativos ao efeito da produção de leite ao $1^{0}$ serviço, avaliada em relação da época de cobertura. Esses resultados demonstram que os animais que aumentaram no verão a produção de leite ao $1^{\circ}$ serviço (calculada com as produções de cinco dias antes e cinco dias após ao $1^{0}$ serviço) tiveram maior chance de sucesso na CPS (OR $=1,057$ e $\left.\mathrm{p} \leq 0,1553\right)$. O efeito da produção de leite durante o inverno não foi significativo ( $\mathrm{OR}=1,001$ e $\mathrm{p} \leq$ 0,9429).

Estes resultados discordam com vários trabalhos que estudaram o efeito da produção de leite sobre a concepção (Eicker et al., 1996; Farin et al., 1994; Grohn et al., 1986 e Nebel \& McGilliard, 1993), contudo estes estudos não avaliaram as produções de leite ao primeiro serviço e os efeitos da época do ano sobre a produção.

Avaliando conjuntamente os resultados dos efeitos da RGP na época da cobertura, e da produção de leite ao $1^{\circ}$ serviço na época da cobertura, pode-se sugerir que os animais que se encontram com melhor condição ruminal (avaliada pela RGP) e produzem maiores quantidades de leite são mais capazes de evitar o efeito do estresse térmico. Porém não se pode esquecer que as produções médias são inferiores durante o verão e que, durante o inverno, quando as produções são superiores, não houve efeito da RGP e nem da produção de leite no $1^{\circ}$ serviço.

O aumento do número de dias em lactação até o $1^{\circ}$ serviço influenciou negativamente a concepção. Quanto mais tarde foi realizado o $1^{\circ}$ serviço, menor foi a CPS obtida (OR $=0,989, \mathrm{p} \leq 0,0670)$. A explicação pode ser devido ao fato de que os animais menos saudáveis, mais afetados pelo balanço energético negativo e por doenças, apresentam falhas no ciclo estral (Thatcher, 1986).

Na avaliação do ECC ao parto, dentro da ocorrência de doenças, foi observado que a cada aumento de uma unidade de ECC as vacas doentes tiveram 1,75 $(\mathrm{p} \leq 0,1427)$ vezes maiores chances de sucesso na CPS, quando comparadas às vacas que não alteraram o ECC. Nos animais não doentes, não houve efeito do ECC ao parto sobre a CPS ( $\mathrm{p} \leq 0,7986)$. Esse resultado indica que vacas doentes, com maior ECC, $(\mathrm{ECC} \leq 4)$ têm a reprodução menos afetada. A explicação pode ser devido ao fato de que os 
animais com melhor condição nutricional (indicada pelo ECC) conseguem superar melhor os efeitos negativos das doenças (Loeffler et al., 1999).

Já as vacas com maior ECC no momento da secagem tiveram a concepção afetada negativamente (OR $=0,734, \mathrm{p} \leq 0,1414)$, diminuindo a CPS a cada aumento de unidade de ECC. Vacas que apresentam maior ECC à secagem $(\geq 4,0)$ são, geralmente, mais susceptíveis a desordens (hipocalcemia, retenção de placenta, metrites, fígado gordo e cetose) e consomem menos alimentos (matéria seca) do que as vacas com ECC adequado (Butler \& Smith, 1989, Grohn \& Schultz, 2000 e Thatcher, 1986). Quando estas são acometidas por desordens metabólicas, de forma crítica, podem chegar ao ECC de 2 unidades ou menos. Além disso, mesmo após a recuperação, quando ganham 35 a $45 \mathrm{~kg}$ de peso, aparentam estarem magras e abatidas, encontrando-se em anestro ou com cistos ovarianos (Studer, 1998).

Em compensação, a cada aumento de uma unidade de ECC no momento da cobertura, os animais tiveram 1,56 ( $\mathrm{p} \leq 0,0523)$ vez mais chances de sucesso a CPS. Ou seja, animais com ECC mais elevado no momento da cobertura apresentaram um balanço nutricional positivo; portanto apresentam melhores condições de reproduzir. Segundo Fergunson (1992) e Fergunson \& Otto (1989), vacas que perdem uma unidade de ECC entre o período do parto e a primeira cobertura tiveram duas vezes menos chances de concepção. Butler \& Smith (1989) e Butler et al. (1981) reportaram que o ECC está diretamente relacionado com o balanço energético negativo (BEN); desta maneira o resultado obtido no presente estudo indica um forte efeito do balanço energético sobre a concepção das vacas leiteiras. As vacas com melhor ECC no momento da cobertura, apresentaram possivelmente um balanço energético negativo não acentuado ou mais tardio. 


\subsection{Conclusões}

Neste rebanho, com alta produção leiteira, foram considerados múltiplos fatores, tais como o número da lactação, a época do ano à cobertura, a relação entre gordura/proteína e a produção de leite na época do $1^{\circ}$ serviço, os dias em lactação ao $1^{\circ}$ serviço, as alterações nos ECC nas diferentes fases da vida produtiva da vaca (secagem e cobertura) e o efeito do ECC ao parto sobre os animais doentes. Todos estes fatores contribuíram para o insucesso na concepção ao $1^{\mathrm{a}}$ serviço.

É difícil isolar um deles como o mais importante, pois agem conjuntamente como um complexo negativo sobre a reprodução, sendo quase que totalmente interdependentes. Esta etiologia multicausal representa um desafio para os técnicos e os produtores de leite. Contudo, a aplicação de técnicas de análises multifatoriais, em dados cuidadosamente coletados neste rebanho comercial, mostrou ser uma forma eficaz de identificar fatores prejudiciais a reprodução.

Para melhorar a taxa de concepção ao primeiro serviço no rebanho estudado, (e conseqüentemente melhorar os índices reprodutivos e a produtividade da atividade leiteira) pode-se realizar o primeiro serviço na época de inverno, (principalmente para as vaca multíparas); devem ser intensos os cuidados com a prevenção, com o diagnóstico precoce e com o tratamento das doenças. As análises de gordura e proteína do leite e a avaliação do escore de condição corporal devem ser incorporadas plenamente no manejo da propriedade, devendo ser realizadas periodicamente, para fornecer desta maneira índices sobre o estado nutricional das vacas; este conjunto de informações deve ser usado para identificar as vacas com risco de insucesso na concepção ao primeiro serviço. 


\section{CONCLUSÃO}

Conclui-se, através dos resultados obtidos, que nas condições do Estado de São Paulo, mesmo em um rebanho bem alimentado e confortavelmente instalado, o desempenho produtivo dos animais é afetado negativamente pela época do ano e a ocorrência de doenças no periparto. Os efeitos deletérios são maiores nos animais multíparos do que nos primíparos quanto à reprodução; porém o inverso ocorre quanto à produção. A magnitude dos efeitos é considerável, chegando a reduzir a eficiência reprodutiva em até $50 \%$ e a produção em até $10 \%$. Esta perda de eficiência pode representar o insucesso na atividade, caso a ocorrência de doenças for acima do normal e se não forem adotadas práticas de manejo que garantam alimentação, conforto e tratamentos curativos adequados. É imperativo que seja avaliada a ocorrência de doenças no periparto, que sejam acompanhadas a composição do leite dos animais e a alteração no escore corporal e que se adotem ações visando reduzir o estresse térmico, a fim de que os pontos fracos do negócio possam ser identificados, permitindo que sejam propostas inovações com o objetivo de minimizá-los ou até mesmo neutralizá-los. 


\section{REFERÊNCIAS BIBLIOGRÁFICAS}

ABILAY, T. A.; JOHNSON, H. D.; MADAN, M. Influence of environmental heat on peripheral plasma progesterone and cortisol during the bovine estrous cycle. Journal of Dairy Science, v.58, p.1836-1840, 1975.

AEBERHARD, K.; BRUCKMAIER, R. M.; KUEPFER, U. et al. Milk yield and composition, nutrition, body conformation traits, body condition scores, fertility and diseases in high-yielding dairy cows - Part 1. Journal of Veterinary Medicine, v.48, p.97-110, 2001.

ALEXANDER, G.; HALES, J. R. S.; STEVENS, D. et al. Effects of acute and prolonged exposure to heat on regional blood flows in pregnant sheep. Journal of Development Physiology, v.9, p.1-15, 1987.

AL-KATANANI, Y. M; WEBB, D. W.; HANSEN, P. J. Factors affecting seasonal variation in non-return rate of lactating dairy cows. Journal of Dairy Science, v.81, suppl.1, p.217, 1998.

AL-KATANANI, Y. M., WEBB, D. W.; HANSEN, P. J. Factors affecting seasonal variation in 90-day nonreturn rate to first service in lactating Holstein cows in a hot climate. Journal of Dairy Science, v.82, p.2611-2616, 1999.

ALMEIDA, R.; RIBAS, N.P.; MONARDES, H. Estudo dos efeitos de meio ambiente sobre as características produtivas de vacas da raça holandesa na região da Batavo, Paraná. In: REUNIÃO ANUAL DA SOCIEDADE BRASILEIRA DE ZOOTECNIA, 34., Juiz de Fora, 1997. Anais. Juiz de Fora: SBZ, 1997. p.65-67.

ANDERSSON, L. Subclinical ketosis in dairy cows. Food Animal Practioners Veterinary Clinics of North America, v.4, p.233-252, 1988.

ANDERSSON, L.; GUSTAFSSON, A. H.; EMMANUELSON, U. Effect of hyperketonemia and feeding on fertility in dairy cows. Theriogenology, v.36, p.521-536, 1991.

ARÉCHIGA, C. F.; EALY, A. D.; HANSEN, P. J. Efficacy of vitamin E and glutathione for thermotolerance of murine morulae. Theriogenology, v.41, p.15451553, 1994. 
ARÉCHIGA, C. F. ; EALY, A. D.; HANSEN, P. J. Evidence that glutathione is involved in thermotolerance of preimplantation murine embryos. Biology Reproduction, v.52, p.1296-1301, 1995.

ARMSTRONG, D. V., DENISE, S. K.; DELFINO, F. J. et al. Comparing thne different dairy cattle cooling system during high environmental temperatures. Journal of Dairy Science, v.7, suppl. 1, p.24, 1994.

BADINGA, L.; COLLIER, R. J.; THATCHER, W. W. et al. Effects of climatic and management factors on conception rate of dairy cattle in subtropical environments. Journal of Dairy Science, v.68, p.78-85, 1985.

BADINGA, L.; THATCHER, W. W.; DIAZ, T. et al. Effect of environmental heat stress on follicular development and steroidogenesis in lactating Holstein cows. Theriogenology, v.39, p.797-810, 1993.

BAGNATO, A.; OLTENACU, P. A. Phenotypic evaluation of fertility traits and their association with milk yield of Italian Fresian Cattle. Journal of Dairy Science, v.77, p.874-882, 1994.

BALIEIRO, J.C.C.; MILAGRES, J.C.; FREITAS, A.F. Aspectos genéticos e fenotípicos em características produtivas do rebanho leiteiro da Universidade Federal de Viçosa. In: REUNIÃO ANUAL DA SOCIEDADE BRASILEIRA DE ZOOTECNIA, 34., Juiz de Fora, 1997. Anais. http://www.sbz.org.br (28 mar. 2003).

BARTLETT, P. C.; KIRK, J. H.; WILKE, M. A. et al. Metritis complex in Michigan Holstein-Friesian cattle: incidence, descriptive epidemiology and estimated economic impact. Preventive Veterinary Medicine, v.4, p.235-248, 1986.

BAUMAN, D. E.; CURRIE, W. B. Partitioning of nutrients during pregnancy and lactation: a review of mechanisms involving homeostasis and homeorhesis. Journal of Dairy Science, v.63, p.1514-1529, 1980.

BEEDE, D. K.; COLLIER, R. J. Potential nutritional strategies for intensively managed cattle during heat stress. Journal of Animal Science, v.62, p.543-549, 1986.

BENDIXEN, P. H.; VILSON, B.; EKESBO, I. et al. Diseases frequencies in dairy cows in Sweden. III. Parturient paresis. Preventive Veterinary Medicine, v.5, p.87-95, 1987.

BERMAN, A.; FOLMAN, Y.; KAIM, M. et al. Upper critical temperatures and forced ventilation effects for high-yielding dairy cows in a subtropical climate. Journal of Dairy Science, v.68, p.1488-1495, 1985.

BIGRAS-POULIN, M.; MEEK, A. H.; MARTIN, S. W. et al. Health problems in selected Ontario Holstein cows: frequency of occurrences, time to first diagnosis and associations. Preventive Veterinary Medicine, v.10, p.79-89, 1990. 
BOISCLAR, Y.; GRIEVE, D. G.; STOWE, J. B. et al. Effect of prepartum energy, body condition, and sodium bicarbonate on production of cows in early lactation. Journal of Dairy Science, v.69, p.2636-2641, 1986.

BONDURANT, R. H. Inflammation in the bovine female reproductive tract. Journal of Dairy Science, v.82, Suppl. 2, p.101-110, 1999.

BONNETT, B. N.; MARTIN, S. W.; MEEK, A. H. Associations of clinical findings, bacteriological and histological results of endometrial biopsy with reproductive performance of postpartum dairy cows. Preventive Veterinary Medicine, v.15, p.205-220, 1993.

BOSU, W. T. K.; PETER, A. T.; Evidence for a role of intrauterine infection in the pathogenesis of cystic ovaries in postpartum dairy cows. Theriogenology, v.28, p.725-733, 1987.

BRUCKENTAL, I.; DRORI, D.; KAIM, M. et al. Effects of source and level of protein on milk yield and reproductive performance of high-producing primiparous and multiparous dairy cows. Animal Production, v.48, p.319-323, 1989.

BUCKLIN, R. A.; TURNER, L. W.; BEEDE, D. K. et al. Methods to relieve heat stress for dauy cows in hot, humid climates. Applied Engineer in Agriculture, v.7, n.2, p.241-247, 1991.

BURKE, J. M.; DE LA SOTA, R. L.; RISCO, C. A. et al. Evaluation of timed insemination using a gonadotropin-releasing hormone agonist in lactating dairy cows. Journal of Dairy Science, v.79, p.1385-1393, 1996.

BUTLER, W. R. Review: effect of protein nutrition on ovarian and uterine physiology in dairy cattle. Journal of Animal Science, v.81, p.2533-2539, 1998.

BUTLER, W. R.; SMITH, R. D. Interrelationships between energy balance and postpartum reproductive function in dairy cattle. Journal of Dairy Science, v.72, p.767-772, 1989.

BUTLER, W.R.; CHERNEY, D.J.R.; ELROD, C.C. Milk urea nitrogen: field trial results on conception rates and dietary inputs. In: CORNELL NUTRITION CONFERENCE FOR FEED MANUFACTURES, Ithaca, 1995. Proceedings , Ithaca: Cornell University, 1995. p. 89-94.

BUTLER, W. R.; EVERETT, R. W.; COPPOCK, C.E. The relationships between energy balance, milk production and ovulation in postpartum Holstein cows. Journal of Animal Science, v.53, p.742-751, 1981.

CALL, E. P.; STEVENSON, J. S. Current challenges in reproductive management. Journal of Dairy Science, v.68, p.2799-2804, 1985.

CAMERON, R.E.B.; DYK, P. B.; HERDT, T. H. et al. Dry cow diet, management, and energy balance as risk factors for displaced abomasum in high producing dairy herds. Journal of Dairy Science, v.81, p.132-139, 1998. 
CANFIELD, R.W; SNIFFEN, C.J.; BUTLER, W.R. Effects of excess degradable protein on postpartum reproduction and energy balance in dairy cattle. Journal of Dairy Science, v.73, n.9, p.2342-2348, 1990.

CARROLL, D. J.; BARTON, B. A.; ANDERSON, G. W. et al. Influence of protein intake and feeding strategy on reproductive performance of dairy cows. Journal of Dairy Science, v.71, p.3470-3481,1988.

CARVALHO, M. P. Manipulação da composição do leite por meio do balanceamento de dietas de vacas leiteiras. In: FONSECA, L. F. L e SANTOS, M. V. Qualidade do leite e controle da mastite. São Paulo: Ed. Lemos, 2000. cap.15, p.163-167.

CASIDA, L.E. Present status of the repeat breeder cow problem. Journal of Dairy Science, v.44, p.2323-2329, 1961.

CASSOLI, L. D.; MACHADO, P. F.; CORASSIN, C. H. et al. Efeitos das ocorrências sanitárias do periparto, sobre o desempenho produtivo e reprodutivo de vacas holandesas. In: SIMPÓSIO INTERNACIONAL DE INICIAÇÃO CIENTÍFICA DA UNIVERSIDADE DE SÃO PAULO, 8., Piracicaba, 2000. Anais. http://www.usp.br/siicusp/8osiicusp/index_2000.htm (24 mar. 2003).

CENTRO DE ESTUDOS AVANÇADOS EM ECONOMIA APLICADA - Preços mensais do leite tipo c. http://www.cepea.usp.br. (21 ago. 2003).

CHALUPA, W.; GALLIGAN, D.T.; FERGUSON, J.D. Animal nutrition and management in the $21^{\text {st }}$ century - dairy cattle. Animal Feed Science and Technology, v.58, p.1-18, 1996.

CHENOWETH, P.J.; LARSEN, R. E. Selection, use and management of natural service bulls. In: VAN HORN, H. H.; WILCOX, C. J. Large dairy herd management. Savoy, American Dairy Science Association, 1992. p.209.

COLE, J. A.; HANSEN, P. J. Effects of administration of recombinant bovine somatotropin on the responses of lactating and nonlactating cows to heat stress. Journal of American Veterinary Medical Association, v.203, p.113-117, 1993.

COLEMAN, D. A.; THANE, W. V.; DAILEY, R. A. Factors affecting reproductive performance of dairy cows. Journal of Dairy Science, v.68, p.1793-1803, 1985.

COLLIER, R. J.; BEEDE, D. K.; THATCHER, W. W. et al. Influences of environment and its modification on dairy animal health and production. Journal of Dairy Science, v.6, p.2213-2219, 1982.

CONSTABLE, P. D.; MILLER, G. Y.; HOFFSIS, G. F. et al. Risk factors for abomasal volvulus and left abomasal displacement in cattle. American Journal of Veterinary Research, v.53, p.1184-1192, 1992.

CORREA, M. T.; CURTIS, R. A.; ERB, H. N. et al. An ecological study of risk factors for postpartum disorders of Holstein-Friesian cows from thirty-two New York farms. Journal of Dairy Science, v.73, p1515-1528, 1990. 
CORREA, M. T.; ERB, H.; SCARLETT, J. Path analysis for seven postpartum disorders of Holsteins cows. Journal of Dairy Science, v.76, p.1305-1311, 1993.

COSTA, C.N.; MILAGRES, J.C.; CASTRO, A.C.G. et al. Efeitos da estação e idade ao parto sobre a curva de lactação de vacas da raça holandesa. Revista da Sociedade Brasileira de Zootecnia, v.11, n.2, p.320-330, 1982.

CUMMINS, K. A. Dietary acid detergent fiber levels for dairy cows during high environmental temperature. Journal of Dairy Science, v.67, suppl. 1, p.516. 1989.

CURTIS, C. R.; ERB, H. N.; SNIFFEN, C. J. et al. Association of parturient hypocalcemia with eight periparturient disorders in Holstein cows. Journal of the American Veterinary Medical Association, v.183, p.559-561, 1983.

CURTIS, C. R.; ERB, H. N.; SNIFFEN, C. J. et al. Epidemiology of parturient paresis: predisposing factors with emphasis on dry cow feeding and management. Journal of Dairy Science, v.67, p.817-823, 1984.

CURTIS, C. R.; ERB, H. N.; SNIFFEN, C. J. et al. Path analysis of dry period nutrition, postpartum metabolic and reproductive disorders, and mastitis in Holsteins cows. Journal of Dairy Science, v.68, p.2347-2360, 1985.

De KRUIF, A. The fertility of a cattle population. In: CONGRESSO BRASILEIRO DE REPRODUÇÃO ANIMAL, 10. Belo Horizonte, 1993. Anais. Belo Horizonte: CBRA, 1993. p.76-82.

DeLUYKER, H. A.; GAY, J. M.; WEAVER, L. D. et al. Change of milk yield with clinical diseases for a high producing dairy herd. Journal of Dairy Science, v.74, p.436-442, 1991.

DISKIN, M.G. Fertility of the high-producing dairy cow. Summaries booklet of a british society of animal science occasional meeting, Galway. In: DISKIN, M.G. (ed.), British Society of Animal Science, v.1, 147-159, 1999.

DOHMEN, M. W.; LOHUIS, J. A. M.; HUSZENICZA, G. et al. The relationship between bacteriological and clinical findings in cows with subacute/chronic endometritis. Theriogenology, v.43, p.1379-1388, 1995.

DOHOO, I. R.; MARTIN, S. W. Disease, production and culling in Holstein cows: III disease and production as determinants of disease. Preventive Veterinary Medicine, v.2, p.671-778, 1984 a.

DOHOO, I. R.; MARTIN, S. W. Disease, production and culling in Holstein-Friesian cows. IV. Effects of disease on production. Preventive Veterinary Medicine, v.2, p.755-770, $1984 \mathrm{~b}$.

DOHOO, I. R.; MARTIN, S. W.; MEEK, A. H. Disease, production and culling in Holstein-Friesian cows. VI. Effects of management on disease rates. Preventive Veterinary Medicine, v.3, p.15-28, 1983. 
DOHOO, I. R.; MARTIN, S. W.; McMILLAN, I. et al. Disease, production and culling in Holstein-Friesian cows. II. Age, season and sire effects. Preventive Veterinary Medicine, v.2, p.655-670, 1984.

DOMECQ, J. J.; SKIDMORE, A. L.; NGWERUME, F. et al. The effect of milk-yieldacceleration in early lactation on first service conception. Journal of Dairy Science, v.75, suppl. 1, p.165, 1992.

DOMECQ, J. J.; SKIDMORE, A. L.; LLOYD, J. W. et al. Validation of body condition scoring with ultrasound measurements of dairy cattle. Journal of Dairy Science, v.78, p.2308-2316, 1995.

DOMECQ, J. J.; SKIDMORE, A. L.; LLOYD, J. W. et al. Relationship between body condition scores and milk yield in a large dairy herd of high yielding Holstein cows. Journal of Dairy Science, v.80, p.101-112, 1997a.

DOMECQ, J. J.; SKIDMORE, A. L.; LLOYD, J. W. et al. Relationship between body condition scores and conception at first artificial insemination in large dairy herd of high yielding Holstein cows. Journal of Dairy Science, v.80, p.113-120, 1997b.

DRANSFIELD, M.B.; NEBEL, R.L.; PEARSON, R.E. et al. Timing of IA for dairy cows identified in estrus by a radio telemetric estrus detection system. Journal of Dairy Science, v.81, p.1874-1882, 1998.

DUFFIELD, T. F.; SANDALS, D.; LESLIE, K. E. et al. Efficacy of monensine of the prevention for the prevention of subclinical ketosis in lactating dairy cows. Journal of Dairy Science, v.81, n.11, p.2866-2873, 1998.

EALY, A. D.; DROST, M.; HANSEN, P. J. Developmental changes in embryonic resistance to adverse effects of maternal heat stress in cows. Journal of Dairy Science, v.76, p.2899-2905, 1993.

EALY, A. D.; ARÉCHIGA, C. F.; BRAY, D. R. et al. Effectiveness of short-term cooling and vitamin $\mathrm{E}$ for alleviation of infertility induced by heat stress in dairy cows. Journal of Dairy Science, v.77, p.3601-3607, 1994.

EALY, A. D.; HOWELL, J. L.; MONTERROSO, V. H. et al. Developmental changes in sensitivity of bovine embryos to heat shock and use of antioxidants as thermoprotectants. Journal of Animal Science, v.73, p.1401-1407, 1995.

EDMONSON, A. J.; LEAN, I. J.; WEAVER, L. D. et al. A body condition scoring chart for Holstein dairy cows. Journal of Dairy Science, v.72, p.68-78, 1989.

EICKER, S. W. Milk production loss after displaced abomasum disease in New York Holsteins. Journal of Dairy Science, v.78, suppl. 1, p.169, 1995.

EICKER, S.W.; GROHN, Y.T.; HERTL, J. A. The associations between cumulative milk yield, days open, and days to first breeding in New York Holsteins Cows. Journal of Dairy Science, v.79, p.235-241, 1996. 
EMANUELSON, U.; OLTENACU, P. A. Incidences and effects of diseases on the performance of Swedish dairy herds stratified by production. Journal of Dairy Science, v.81, p.2376-2383, 1998.

EMANUELSON, U.; OLTENACU, P. A.; GROHN, Y. T. Nonlinear mixed model analyses of five production disorders of dairy cattle. Journal of Dairy Science, v.76, p.2765-2772, 1993.

EMERY, R. S. Feeding for milk components. Large Animal Veterinarian, v.46, n.3, p. 30-33, 1991.

ERB, H. N. Interrelationships among production and clinical disease in dairy cattle: A review. Canadian Veterinary Journal, v.28, p.326-329, 1987.

ERB, H. N.; GROHN, Y. T. Epidemiology of metabolic disorders in the periparturient dairy cows. Journal of Dairy Science, v.71, p.2557-2571, 1988.

ERB, H. N.; SMITH, R. D. The effects of periparturient events on breeding performance of dairy cows. Veterinary Clinics of North America: Food Animal Practice, v.3, p.501-503, 1987.

ERB, R. E.; WILBUR, J. W.; HILTON, J. H. Some factors affecting breeding efficiency in dairy cattle. Journal of. Dairy Science, v.23, p.549, 1940.

ERB, H. N.; MARTIN, S.W.; ISON, N. et al. Interrelationships between production and reproductive diseases in Holstein cows. Path analysis. Journal of Dairy Science, v.64,p.282-289, 1981.

ERB, H. N.; SMITH, R. D.; HILLMAN, P. A. et al. Rates of diagnosis of six diseases of Holsteins cows during 15-day and 21-day intervals. American Journal of Veterinary Research. v.2, p.333-337, 1984.

ERB, H. N.; SMITH, R. D.; OLTENACU, P. A. et al. Path model of reproductive disorders and performance, milk fever, mastitis, milk yield, and culling in Holstein cows. Journal of Dairy Science, v.68, p.3337-3345, 1985.

FALLON, G. R. Body temperature and fertilization in cow. Journal of Reproduction Fertility, v.3, p.116-118, 1962.

FARIN, P. W.; SLENNING, B. D.; CORREA, M. T. et al. Effects of calving season and milk yield on pregnancy risk and income in North Caroline holsteins cows. Journal of Dairy Science, v.77, p.1848-1855, 1994.

FAUST, M. A.; McDANIEL, B. T.; ROBINSON, O. W. et al. Environmental and yield effects on reproduction in primiparous Holsteins. Journal of Dairy Science, v.71, p.3092-3105, 1988.

FERGUSON, J. D. Body condition scoring. In: ADVANCED DAIRY CATTLE NUTRITION SEMINNAR AMERICAN ASSOCIATION OF BOVINE PRACTIONERS. Conference, Minneapolis, MN, AABP, 1992. p.78. 
FERGUSON, J. D.; OTTO, K. A. Managing body condition in dairy cows. In: CORNELL NUTRITION CONFERENCE FEED MANUFACTURES, Syracuse, 1989: Proceedings. Syracuse: Cornell University, 1989. p.79.

FERGUSON, J. D.; CHALUPA, W. Impact of protein nutrition on reproduction in dairy cows. Journal of Dairy Science, v.72, p.746-752, 1989.

FERGUSON, J. D.; BLANCHARD, T.; GALLIGAN, D.T. et al. Infertility in dairy cattle fed a high percentage of degradable of protein degradable in the rumen. Journal of the American Veterinary Medical Association, v.192, p.659-662, 1988.

FLEISHER, P.; HOEDEMARKER, M.; METZNER, M. et al. Clinical disorders in Holstein cows: Incidence and association among lactation risk factors. Acta Veterinária, v.70, p.157-165, 2001.

FOLMAN, Y.; NEUMARK, H.; KAIM, M. et al. Performance, rumen and blood metabolites in high-yielding cows fed varying protein percents and protected soybean. Journal of Dairy Science, v.64, p.759-768, 1981.

FONSECA, L. F. L. Suplementação de propileno glicol para vacas leiteiras periparturientes: efeitos sobre o metabolismo, condição corporal, produção e reprodução. São Paulo, 1997. 114p. Dissertação (Doutorado) Faculdade de Medicina Veterinária e Zootecnia, Universidade de São Paulo.

FONSECA, L. F. L.; SANTOS, M. V. Qualidade do leite e controle da mastite. São Paulo: Ed. Lemos. 2000. 189 p.

FRANCOS, G.; MACER, E. Observations on some environmental factors connected with fertility in heat-stressed cows. Theriogenology, v.19, p.625-634, 1983.

FRONK, T. J.; SCHULTZ, L. H.; HARDIE, A. R. Effect of dry period overconditioning on subsequent metabolic disorders and performance of dairy cows. Journal of Dairy Science, v.63, p.1080-1090, 1980.

FUQUAY, J. W. Heat stress as it affects animal production. Journal of Animal Science, v.52, p.164-174, 1981.

GANGWAR, P. C.; BRANTON, C.; EVANS, D. L. Reproductive and physiological responses of Holstein heifers to controlled and natural climatic conditions. Journal of Dairy Science, v.48, p.222-227, 1965.

GARNSWORTHY, P. C. The effect of energy reserves at calving on performance of dairy cows. In: GARNSWORTHY, P. C. Nutrition and lactation in the dairy cow. London: Butterworths, 1988. p.157.

GASPARINO, E. Estudo de fatores genéticos e de meio que influenciam o desempenho de vacas mestiças à primeira cria. Viçosa, 1996. 112p. Dissertação (Mestrado) Universidade Federal de Viçosa. 
GEARHART, M. A.; CURTIS, C. R.; ERB, H. N. et al. Relationship of changes in condition score to cow health in Holsteins. Journal of Dairy Science, v.73, p.3132-3143, 1990.

GEISHAUSER, T.; SHOUKRI, M.; KELTON, D. et al. Analysis of survivorship after displaced abomasum is diagnosed in dairy cows. Journal of Dairy Science, v.81, p.2346-2353, 1997.

GIER, H. T.; MARION, G. B. Uterus of the cow after parturition: involutional changes. American Journal of Veterinary Research, v.29, p.83-96, 1968.

GODDEN, S. M.; KELTON, D. F.; LISSEMORE, K. D. et al. Milk urea testing as a tool to monitor reproductive performance in ontario dairy herds. Journal of Dairy Science, v.84, p.1397-1406, 2001.

GOERING, H. K.; VAN SOEST, P. J. Forage fibre analyses: apparatus, reagents, procedures and some applications. Washington: USDA, 1970, 379 p.

GROHN, Y. T.; RAJALA-SCHULTZ, P. J. Epidemiology of reproductive performance in dairy cows. Animal Reproduction Science, v.61, p.605-614, 2000.

GROHN, Y. T.; EICKER, S. W.; HERTL, J. A. The association between previous 305day milk yield and disease in New York state dairy cows. Journal of Dairy Science, v.78, p.1693-1702, 1995.

GROHN, Y. T.; SALONIEMI, H.; SYVAJARVI, J. An epidemiological and genetic study on registered diseases in Finnish Ayrshire cattle I. Acta Veterinaria Scandinavian, v.27, p.182-189, 1986.

GROHN, Y. T.; ERB, H. N.; MCCULLOCH, C. E. et al. Epidemiology of metabolic disorders in dairy cattle: Association among host characteristics, disease and production. Journal of Dairy Science, v.72, p.1876-1885, 1989.

GROHN, Y. T.; ERB, H. N.; McCULLOCH, C. E. et al. Epidemiology or reproductive disorders in dairy cattle: associations among host characteristics, disease and production. Preventive Veterinary Medicine, v.8, p.25-29, 1990.

GRUMMER, R R. Influence of prilled fat and calcium salt of palm oil fatty acids on ruminal fermatation and nutrient digestibility. Journal of Dairy Science, v.71, p.117-122, 1988.

GRUMMER, R R. Etiology of lipid-related metabolic disorders in periparturient dairy cows. Journal of Dairy Science, v.76, n.12, p.3882-3886, 1993.

GRUNERT, E. Etiology and pathogenesis of retained bovine placenta. In: MORROW, D. A. Current therapy in theriogenology. Philadelphia: Saunders, 1986. p.237242.

GRYMER, J. Displaced abomasum-a disease often associated with concurrent disease. Compendium of Continued Educational Practioner Veterinary, v.11, p.290295, 1980. 
GUARD, C. Abomasal displacement and volvulus. In: SMITH, B. P. Large animal internal medicine. St. Louis: Mosby, 1990. p.792

GUARD, C. Metabolic Diseases: a herd approach .In: REBHUN, W. C.; GUARD, C.; RICHARD, C. M. Diseases of dairy cattle. New York: Wiliams \& Wilkins, 1995. p.497-510.

GUARD, C.L. Fresh cow problems are costly: Culling hurts the most. Hoard's Dairyman, v.141, p.8, 1996.

GUNNINK, J. W. Retained placenta and leukocytic activity. Veterinary Qualification, v.6, p.49-51, 1984.

GUSTAFSSON, A. H.; ANDERSSON, L.; EMMANUELSON, U. Effect of hiperketonemia, feeding frequency and intake of concentrate and energy on milk yield in dairy cows. Animal Production, v.55, n.1, p. 51-60, 1993.

GWAZDAUSKAS, F. C. Effects of climate on reproduction in cattle. Journal of Dairy Science, v.68, p.1568-1578, 1985.

GWAZDAWSKAS, F. C.; WILCOX, J. C.; THATCHER, W. W. Environmental and management factors affecting conception rate in a subtropical climate. Journal of Dairy Science, v.58, p.88-93, 1975.

HANSEN, L. B. Consequences of selection for milk yield from a geneticist's viewpoint. Journal of Dairy Science, v.83, p.1145-1150, 2000.

HANSEN, P. J. Estratégias para reduzir os efeitos do estresse térmico na eficiência reprodutiva. In: CURSO NOVOS ENFOQUES NA PRODUÇÃO E REPRODUÇÃO DE BOVINOS, Uberlândia, 2003. Anais. Uberlândia: Conapec, 2003. p.77-97.

HANSEN, P. J.; THATCHER, W. W.; EALY, A. D. Methods for reducing effects of heat stress on pregnancy. In: VAN HORN, H. H.; WILCOX, C. J. Large dairy herd management. Savoy, American Dairy Science Association, 1992. p.116-125.

HEINRICHS, A.J.; BUCKMASTER, D.R.; LAMMERS, B.P. A review: processing, mixing, and particle size reduction of forages for dairy cattle. Journal of Animal Science, v.77, p.180-186, 1999.

HER, E., WOLFENSON, D.; FLAMEMBAUM, I. et al. Thermal, productive, and reproductive responses of high yielding cows exposed to short-term cooling in summer. Journal of Dairy Science, v.71, p.1085-1092, 1988.

HETTINGA, D. A. Why alter milk composition? Journal of Dairy Science, v.72, p.2790-2800, 1989.

HEUER, C.; SHUKKEN, Y.H.; DOBBELAAR, P. Postpartum body condition score and results from the first test day milk as predictors of disease, fertility, yield, and culling in commercial dairy herds. Journal of Dairy Science, v.82, p.295-304, 1999. 
HIBBS, J. W. Milk fever (parturient paresis) in dairy cows: a review. Journal of Dairy Science, v.33, p.758-764, 1950.

HOEKSTRA, J.; VAN DER LUGT, A. W.; VAN DER WERF, J. H. J. et al. Genetic and phenotypic parameters for milk production and fertility traits in upgraded dairy cattle. Livestock Production Science, v.40, p.225-232, 1994.

HORST, R. L.; GOFF, J. P.; REINHARDT, T. A. et al. Strategies for preventing milk fever in dairy cattle. Journal of Dairy Science, v.80, p.1269-1280, 1997.

HOWARD, H. J.; AALSETH, E. P.; ADAMS, G. D. et al. Influence of dietary protein on reproductive performance of dairy cows. Journal of Dairy Science, v.70, p.1563-1571, 1987.

HULL, B. L.; WASS, W. M. Abomasal displacement. 2: Hypocalcemia as a contributing causative factor. Veterinary Medicine Small Animal Clinic, v.68, p.412-417, 1973.

HULME, M. Global warning. Progressive Philosophy Geography, v.21, p.446-453, 1997.

HURLEY, W. L.; DOANE, R. M. Recent developments in the roles of vitamins and minerals in reproduction. Journal of Dairy Science, v.72, p.784-804, 1989.

HUSSAIN, A. M. Bovine uterine defense mechanism: a review. Journal of Veterinary Medicine, v.36, p.641-650, 1989.

HUTJENS, M. F. Evaluating nutritional management changes. WESTERN DAIRY MANAGEMENT CONFERENCE, 5., Las Vegas, 2001. Proceedings. Nevada: AABP, 2001. p.139-146.

INTERNATIONAL DAIRY FEDERATION. IDF Standard Method n. ${ }^{\circ}$ 141b. 1996. Whole milk determination of milk fat, protein and lactose content. IDF Committee, Brussels, Belgium.

IGONO. M. O.; JOHNSON, H. D.; STEEVENS, B. J. et al. Physiological, productive and economic benefits of shade, spray, and fan system versus shade for Holstein cows during summer heat. Journal of Dairy Science, v.70, p.1069-1076, 1987.

INGRAHAM, R H.; TIDETTE, D. D.; WAGNER, W. D. Relationship of temperature and humidity to conception rate of Holstein cows in subtropical climate. Journal of Dairy Science, v.57, p.476-482, 1974.

JONKER, J.S.; KOHN, R.A.; ERDMAN, R.A. Using milk urea nitrogen to predict nitrogen excretion and utilization efficiency in lactating dairy cows. Journal of Dairy Science, v.81, p.2681-2692, 1999.

JOOSTEN, I.; VAN ELDIK, P.; ELVING, L. et al. Factors related to the etiology of retained placenta in dairy cattle. Animal Reproduction Science, v.14, p.251-262, 1987. 
JORDAN, E. R.; FOURDRAINE, R. H. Characterization of the management practices of the top producing herds in the country. Journal of Dairy Science, v.76, p.32473256, 1993.

KAIM, M.; FOLMAN, Y.; NEUMARK, H. et al. The effect of protein intake and lactation number on post-part body weight loss and reproductive performance of dairy cows. Animal Production, v.37, p.229-236, 1983.

KING, V. L.; DENISE, S. K.; ARMSTRONG, D. V. et al. Effects of a hot climate on the performance of first lactation Holstein cows grouped by coat color. Journal of Dairy Science, v.71, p.1093-1096, 1988.

KOHN, R.A. Caution needed when interpreting MUN. Hoard's Dairyman, v.145, n.2, p.58, 2000.

LAGO, E. P. Avaliação da incidência de cetose em vacas leiteiras. Piracicaba, 1997. 88p. Dissertação (Mestrado) - Escola Superior de Agricultura “Luiz de Queiroz”, Universidade de São Paulo.

LAGO, E. P.; PIRES, A. V.; SUSIN, I.. Efeito da condição corporal ao parto sobre alguns parâmetros do metabolismo energético, produção de leite e incidência de doenças no pós-parto de vacas leiteiras. Revista Brasileira de Zootecnia, v.30, n.5, p.1544-1549, 2001.

LAMMERS, B.P.; BUCKMASTER, D.R.; HEINRICHS, A. J. A simple method for the analysis of particle sizes of forage and total mixed rations. Journal of Dairy Science, v.79, p.922-928, 1996.

LAMOND, D. R. The influence of undernutrition on reproduction in the cow. Animal Breeding Abstracts, v.38, p.359-372, 1970.

LARSON, S.F.; BUTLER, W.R.; CURRIE, W.B. Reduced fertility associated with low progesterone postbreeding and increase milk urea nitrogen in lactating cows. Journal of Dairy Science, v.80, n.7, p.1288-1294, 1997.

LAVEN, R. A.; PETERS, A. R. Bovine retained placenta: Aetiology, pathogenesis and economic loss. Veterinary Records, v.139, p.465-471, 1996.

LEAN, I. J.; BRUSS, M. L.; BALDWIN, R. L. et al. Bovine ketosis: 1 Epidemiology and pathogenesis. Veterinary Bulletin, v.61, p.1209-1218, 1991.

LEAN, I. J.; BRUSS, M. L.; BALDWIN, R. L. et al. Bovine ketosis: a review. II. Biochemistry and Prevention. Veterinary Bulletin, v.61, p.11-18, 1992.

LEWIS, G. S. Uterine Health and Disorders. Journal of Dairy Science, v. 80, p.984994, 1997.

LINN, J. G. Altering the composition of milk through management practice. Feedstuffs, v.61, n.17, p.18-23, 1991. 
LOEFFLER, S.H.; VRIES, M.; SHUKKEN, Y.H. The effects of time of disease occurrence, milk yield, and body condition on fertility of dairy cows. Journal of Dairy Science, v.82, p.2589-2604, 1999.

LOEFFLER, S.H.; VRIES, M.; SHUKKEN, Y.H. et al. Use of AI technician score for body condition, uterine tone and uterine dischard in a model with disease and yield parameters to predict pregnancy risk at first AI in Holsteins dairy cows. Theriogenology, v.51, p.1267-1284, 1998.

LUCEY, S.; ROWLANDS, G. J.; RUSSELL, A. Short-term associations between disease and milk yield of dairy cows. Journal of Dairy Research, v.53, p.7-15, 1986.

LUCY, M. C. Reproductive loss in high-producing dairy cattle: where will it end ?. Journal of Dairy Science, v.84, p.1277-1293, 2001.

MACHADO, P. F. Componentes do Leite. Apresentado ao Encontro nacional da associação dos criadores de gado jersey do brasil. Piracicaba, 2003.

MACMILLAN, K.L.; LEAN, I.J.; WESTWOOD, C.T. The effects of lactation on the fertility of dairy cows. Australian Veterinary Journal, v.73, p.141-147, 1996.

MADAN, M. L.; JOHNSON, H. D. Environmental heat effects on bovine luteinizing hormone. Journal of Dairy Science, v.56, p.1420-1423, 1973.

MARKUSFELD, O. Factors responsible for parturient metritis in dairy cattle. Veterinary Records, v.114, p.539-544, 1984.

MARKUSFELD, O. Periparturient traits in seven high dairy herds. Incidence rates, association with parity, and interrelationships among traits. Journal of Dairy Science, v.70, p.158-166, 1987.

MARKUSFELD, O. Periparturient traits in seven high dairy herds: incidence rates, association with parity, and interrelationships among traits. Journal of Dairy Science, v.70, p.158-164, 1990.

MARTIN, J. M.; WILCOX, C. J.; MOYA, J. et al. Effects of retained fetal membranes on milk production and reproductive performance. Journal of Dairy Science, v.69, p.1166-1171, 1986.

MARTIN, T.G. Production and longevity in dairy cattle. In: VAN HORN, H. H.; WILCOX, C. J. Large dairy herd management. Savoy, American Dairy Science Association, 1992. p.50-55.

MARTIN, W. Left abomasal displacement: an epidemiological study. Canadian Veterinary Journal, v.13, p.61-68, 1972.

MASSEY, C. D.; WANG, C.; DONOVAN, G. A. et al. Hypocalcemia at parturition as a risk factor for left displacement of the abomasum in dairy cows. Journal of the American Veterinary Medical Association, v.203, p.852-853, 1993. 
MATOS, R.S.; RORATO, P.R.N.; FERREIRA, G.B. et al. Estudo do efeito de alguns fatores de meio sobre as produções de leite e gordura da raça holandesa no Rio Grande do Sul. In: REUNIÃO ANUAL DA SOCIEDADE BRASILEIRA DE ZOOTECNIA, 33., Fortaleza, 1996. Anais. http://www.sbz.org.br (24 mar. 2003).

McDOWELL, R. E.; WILK, J. C.; TALBOTT, C. W. Economic viability of crosses of Bos taurus and Bos indicus for dairying in warm climates. Journal of Dairy Science, v.79, n.7, p.1292-1303, 1996.

MELENDEZ, P., DONOVAN, A.; HERNADEZ, J. Milk urea nitrogen and infertility in Florida Holstein Cows. Journal of Dairy Science, v.83, p.459-468, 2000.

MIETTINEN, P. V. A.; SETALA, J. J. Relationships between subclinical ketosis, milk production and fertility in Finnish dairy cattle. Preventive Veterinary Medicine, v.17, p.1-8, 1993.

MILLER, H. V.; KIMSEY, P. B.; KENDRICK, J. W. et al. Endometritis of dairy cattle: diagnosis, treatment, and fertility. Bovine Practitioner, v.15, p.13-23, 1980.

MOORE, R. B.; FUQUAY, J. W.; DRAPALA, W. J. Effects of late gestation heat stress on postpartum milk production and reproduction in dairy cattle. Journal of Dairy Science, v.75, p.1877-1882, 1992.

MORRISON, S. R. Ruminant heat stress: Effect on production and means of alleviation. Journal of Animal Science, v.57, p.1594-1608, 1983.

MORROW, D. A. Fat cow syndrome. Journal of Dairy Science, v.59, p.1625-1631, 1975.

MORROW, D. A.; ROBERTS, S. J.; McENTEE, K. et al. Postpartum ovarian activity and uterine involution in dairy cattle. Journal of the American Veterinary Medical Association, v.149, p.1596-1609, 1966.

MORROW, D. A; HILLMAN, D.; DADE, W. et al. Clinical investigation of dairy herd with fat cow syndrome. Journal of the American Veterinary Medical Association, v.174, p.161-164, 1979.

MOTA, A.F.; VERNEQUE, R.S.; PORTELA, J.S. et al. Curvas de lactação de vacas holandesas do rebanho do CPPSUL - EMBRAPA - Bagé - RS. In: REUNIÃO ANUAL DA SOCIEDADE BRASILEIRA DE ZOOTECNIA, 33., Fortaleza, 1996. Anais. http://www.sbz.org.br (24 mar. 2003).

MICHIGAN STATE UNIVERSITY. Software Spartan (disquete). Michigan: MSU, Animal Science Department, Cooperative Extension Service,1992.

NATIONAL RESEARCH COUNCIL. Nutrient requirements of dairy cattle. Washington: National Academy of Science, 2001. 381 p.

NEBEL, R. L.; McGILLIARD, M. L. Interactions of high milk yield and reproductive performance in dairy cows. Journal of Dairy Science, v.76, p.3257-3304, 1993. 
NEBEL, R. L.; JOBST, S. M. Evaluation of systematic breeding programs for lactating dairy cows: a review. Journal of Dairy Science, v.81, p.1169-1174, 1998.

OETZEL, G. R. Effects of prophylactic treatment with a calcium chloride gel on serum calcium concentration at calving, milk fever, and displaced abomasum in Holstein cows. Journal of Dairy Science, v.76, suppl. 1, p.304, 1993.

OETZEL, G. R.; OLSON, J. D.; CURTIS, C. R. et al. Ammonium chloride and ammonium sulfate for prevention of parturient paresis in dairy cows. Journal of Dairy Science, v.71, p.3302-3312, 1988.

OLDHAM J. D. Protein-energy interrelationships in dairy cows. Journal of Dairy Science, v.67, p.1090-1098, 1984.

OLDS. D.; COOPER, T.; THRIFT; F. A. Effect of days open on economic aspects of lactation. Journal of Dairy Science, v.62, p.1167-1173, 1979.

OLTENACU, P. A.; BRITT, J. H.; BRAUN, R. K. et al. Relationships among type of parturition, type of discharge from genital tract, involution of cervix, and subsequent reproductive performance in Holstein cows. Journal of Dairy Science, v. 66, p.612-617, 1983.

OLTENACU, P. A.; FRICK, A.; LINDHE, D. B. Epidemiological studies of several diseases, reproductive performance, and culling in primiparous Swedish cattle. Preventive Veterinary Medicine, v.9, p.59-74, 1990.

OSTERGAARD, S.; SORENSEN, J.T.; KRISTENSEN, A.R. A stochastic model simulating the feeding-health-production complex in a dairy herd. Journal of Dairy Science, v.83, n.4, p.721-733, 2000.

OTTO, K. L.; FERGUSON, J. D.; FOX, D. G. et al. Relationship between body condition score and composition of ninth to eleventh rib tissue in Holstein dairy cows. Journal of Dairy Science, v.74, p.852-859, 1991.

PAYNE, J. M. Outlook on milk fever. Outlook on Agriculture, v.5, p.266, 1968.

PEDRON, O.; CHELI, F.; SENATORE, E. et al. Effect of body condition score at calving on performance, some blood parameters, and milk fatty acid composition in dairy cows. Journal of Dairy Science, v.76, n.9, p.2528-2535, 1993.

PEHRSON, B. G.; SHAVER, R. D. Displaced abomasum: clinical data and effects of peripartal feeding and management on incidence. In: AM. ASSOC. BOVINE PRACT. CONF., St. Paul, MN. Proceedings. Stillwater, OK: American Association of Bovine Practioners, 1992. p.116-121.

PERKINS, B. L.; SMITH, R. D.; SNIFFEN, C. J. Body condition scoring: a useful tool for dairy herd management. In: SMITH, R. D. Dairy management fact sheet. Ithaca: Cornel1 University, Cooperative. Extension, 1985. p.8.

PETERS, A. R. Herd management for reproductive efficiency. Animal Reproduction Science, v.42, p.445-450, 1996. 
PIRES, A.V. Fatores genéticos e ambientais que afetam a produção de leite e a duração da lactação de um rebanho com diferentes grupos genéticos holandês:guzerá. Piracicaba, 1984. 112p. Dissertação (Mestrado) - Escola Superior de Agricultura “Luiz de Queiroz”, Universidade de São Paulo.

PRYCE, J. E.; COFFEY, M. P.; BROTHERSTONE, S. The genetic relationship between calving interval, body condition score and linear type and management traits in registered Holsteins. Journal of Dairy Science, v.83, p.2664-2671, 2000.

PRYCE, J. E.; ESSLEMONT, R. J.; THOMPSON, R. et al. Estimation of genetic parameters using health, fertility and production data from a management recording system for dairy cattle. Animal Science, v.66, p.577-584, 1998.

PRYCE, J. E.; VEERKAMP, R. F.; THOMPSON, R. et al. Genetic aspects of common health disorders and measures of fertility in Holstein Friesian dairy cattle. Animal Science, v.65, p.353-360, 1997.

PURSLEY, J. R.; MEE, M. O.; WILTBANK, M. C. Synchronization of ovulation in dairy cows using PGF $_{2} \alpha$ and GnRH. Theriogenology, v.44, p.915-923, 1995.

PURSLEY, J. R.; WILTBANK, M. C.; STEVENSON, J. S. et al. Pregnancy rates per artificial insemination for cows and heifers inseminated at a synchronized ovulation or synchronized estrus. Journal of Dairy Science, v.80, p.295-300, 1997 a.

PURSLEY, J. R.; KOSOROK, M. R.; WILTBANK, M. C. Reproductive management of lactating dairy cows using synchronization of ovulation. Journal of Dairy Science, v.80, p.301-306, 1997b.

PURSLEY, J.R.; SILCOX, R.W.; WITTBANK, M. C. Effect of timed AI on pregnancy rates, calving rates, pregnancy loss, and gender ratio after synchronization of ovulation in lactating dairy cows. Journal of Dairy Science, v.81, p.2139-2144, 1998

QUEIROZ, S.A.; GIANNONI, M.A.; RAMOS, A.A. et al. Environmental effects on the variation of productive traits in Holstein-Friesian $\times$ Zebu cross-bred cattle in the region of São Carlos, State of São Paulo, Brazil. I. Milk yield. Revista Brasileira de Genética, v.10, n.1, p.63-73, 1987.

RAIZMAN, E. A; SANTOS, J. E. P. The effect of left displacement of abomasum corrected by toggle-pin suture on lactation, reproduction, and health of holstein dairy cows. Journal of Dairy Science, v.85, p.1157-1164. 2002.

RAJALA, P. J.; GROHN, Y. T. Disease occurrence and risk factor analysis in Finnish Ayrshire cows. Acta Veterinary Scandinavian, v.39, p.1-13, 1998a.

RAJALA, P. J.; GROHN, Y. T. Effects of dystocia, retained placenta, and metritis on milk yield in dairy cows. Journal of Dairy Science, v.81, p.3172-3181, 1998 b.

RAJALA-SCHULTZ, P.J.; SAVILLE, W.J.A.; FRAZER, G.S. et al. Association between milk urea nitrogen and fertility in Ohio dairy cows. Journal of Dairy Science, v.84, n.2, p.482-491, 2001. 
RAMBERG, C. F.; JOHNSON, E. K.; FARGO, R. D. et al. Calcium homeostasis in cows, with special reference to parturient hypocalcemia. American Journal of Physiology, v.246, p.698-703, 1984.

RAVAGNOLO, O.; MISZTAL, I. Genetic component of heat stress in dairy cattle, parameter estimation. Journal of Dairy Science, v.83, p.2126-2130, 2000.

RAVAGNOLO, O.; MISZTAL, I.; HOOGENBOOM, G. Genetic component of heat stress in dairy cattle, development of heat index function. Journal of Dairy Science, v.83, p.2120-2125, 2000.

RAY. D. E.; HALBACH, T. R.; ARMSTRONG, D. V. Season and lactation number effects on milk production and reproduction in dairy cattle in Arizona. Journal of Dairy Science, v.75, p.2976-2982, 1992.

RIBAS, N.P.; MONARDES, H.; MOLENTO, C.F.M. et al. Estudo dos efeitos de meio ambiente sobre as características produtivas de vacas da raça holandesa no Estado do Paraná. In: REUNIÃO ANUAL DA SOCIEDADE BRASILEIRA DE ZOOTECNIA, 33., Fortaleza, 1996b. Anais. http://www.sbz.org.br (24 mar. 2003)

RISCO, C. A. Calving related disorders. In: VAN HORN, H. H.; WILCOX, C. J. Large dairy herd management. Savoy, American Dairy Science Association, 1992. p.193-198.

RISCO, C. A.; REYNOLDS, J. P.; HIRD, D. Uterine prolapse and hypocalcemia in dairy cows. Journal of the American Veterinary Medical Association, v.185, p.1517-1519, 1984.

RISCO, C.A.; DONOVAN, G.A.; HERNANDEZ, J. Clinical mastitis associated with abortion in dairy cows. Journal of Dairy Science, v.82, p.1684-1689, 1999.

ROBB, E. J.; JOHNSTONE, C.; BARTON, C. et al. Epidemiologic study of risk factors for abomasal displacement. Journal of Dairy Science, v.69, suppl. 1, p.105, 1986.

ROBERTS, S. J. Puerperal infections, uterine infections and diseases. In: ROBERTS, S. J. Veterinary obstetrics and genital diseases. Woodstock: David \& Charles,1986. p.373-393.

ROCHE, J.F.; MACKEY, D.; DISKIN, M.D. Reproductive management of postpartum cows. Animal Reproduction Science, v.61, p.703-712, 2000.

ROMAN-PONCE, H.; THATCHER, W. W.; BUFFINGTOM, D. E. et al. Physiological and production responses of dairy cattle to a shade structure in a subtropical environment. Journal of Dairy Science, v.60, p.424-429, 1977.

ROMAN-PONCE, H.; THATCHER, W. W.; WILCOX, C. J. Hormonal interrelationships and physiological responses of lactating dairy cows to a shade management system in a subtropical environment. Theriogenology, v.16, p.139154, 1981. 
ROSELER D. K.; FERGUSON J. D.; SNIFFEN C. J. et al. Dietary protein degradability effects on plasma and milk urea nitrogen and milk nonprotein nitrogen in Holstein Cows. Journal of Dairy Science, v.76, p.525-534, 1993.

ROSENBERG, M.; FOLMAN, Y.; HERZ, Z. et al. Effect of climatic conditions on peripheral concentrations of $\mathrm{LH}$, progesterone and estradiol-17b in high milkyielding cows. Journal of Reproduction Fertility, v.66, p.139-154, 1982.

ROUSH, W. Population - the view from Cairo. Science, v.265, p.1164-1167. 1994.

ROWLANDS, G. J.; LUCEY, S. Changes in milk yield in dairy cows associated with metabolic and reproductive disease and lameness. Preventive Veterinary Medicine, v.4, p.205-221, 1986.

ROYAL, M.D.; DARWASH, A.O.; FLINT, P.F. et al. Declining fertility in dairy cattle: changes in traditional and endocrine parameters of fertility. Animal Science, v.70, p.487-502, 2000.

RUEGG, P. L. Body condition scoring in Holstein dairy cows: relationships with production, reproduction, and disease. In: AMERICAN ASSOCIATION OF BOVINE PRACTIONERS, Albuquerque, 1994. Proceedings., Stillwater: Frontier Printers, 1994. p.176.

RUEGG, P. L.; MILTON, R. L. Body condition scores of Holstein cows on Prince Edward Island, Canada: relationships with yield, reproductive performance, and disease. Journal of Dairy Science, v.78, p.552-559, 1995.

RUEGG, P. L.; GOODGER, W. J.; HOLMBERG, C. A. et al. Relation among body condition score, serum urea nitrogen and cholesterol concentrations, and reproductive performance in high-producing Holstein dairy cows in early lactation. American Journal of Veterinary Research, v.53, p.10-16, 1992.

SANDALS, W. C.; CURTIS, R. A.; COTE, J. F. et al. The effect of retained placenta and metritis complex on reproductive performance in dairy cattle-a case control study. Canadian Veterinary Journal, v.20, p.131-135, 1979.

SARGEANT, J. M.; SCHUKKEN, Y. H.; LESLIE, K. E. Ontario bulk milk somatic cell count reduction program: progress and outlook. Journal of Dairy Science, v.81, n.6, p.1545-1554, 1998.

SAS INSTITUTE. SAS/STAT: user's guide 8.0 (compact disc). Cary, 1999.

SCHLATTER, L. The addition of nutrocal to the diets of periparturient cows: a review. Gainesville: Kemin Industries, 1997. 11p. (Technical Information).

SCHMITT, E.J.; DIAZ, T.; DROST, M. et al. Use of gonadotropin-releasing hormone agonist or human chorionic gonadotropin for timed insemination in cattle. Journal of Animal Science, v.74, p.1084-1091, 1996.

SEATH, D. M.; STAPLES, C. H. Some factors influencing the reproductive efficiency of Lousiana herds. Journal of Dairy Science, v.24, p.510, 1941. 
SEYKORA, A. J.; McDANIEL, B. T. Heritabilities and correlations of lactation yields and fertility for Holsteins. Journal of Dairy Science, v.66, p.1486-1492, 1983.

SHANKS ,R D.; FREEMAN, A.E.; BERGER, P.J. et al. Effect of selection for milk production on reproductive and general health of the dairy cow. Journal of Dairy Science, v.61, p.1765-1972, 1978.

SHAVER, R. D. Nutritional risk factors in the etiology of left displaced abomasum in dairy cows: a review. Journal of Dairy Science, v.80, p.2449-2453, 1997.

SILVA, H. M.; WILCOX, C. J.; THATCHER, W. W. et al. Factors affecting days open, gestation length, and calving interval in Florida dairy cattle. Journal of Dairy Science, v.75, p.288-294, 1992.

SIMERL, N. A.; WILCOX, C. J.; THATCHER, W. W. Postpartum performance of freshening at young ages dairy heifers. Journal of Dairy Science, v.75, p.590-595, 1992.

SMITH, J. F.; PAYNE, E.; TWIT, H. R. et al. The effect of suckling upon the endocrine changes associated with anestrus in identical twin dairy cows. Journal of Reproduction and Fertility, v.30, p.241-248, 1981.

SORENSON, J. T.; ENEVOLDSEN, C. Effect of dry period length on milk production in subsequent lactation. Journal of Dairy Science, v.74, p.1277-1285, 1991.

STAPLES, C.R.; THATCHER, W.W.; CLARK, J.H. Relationship between ovarian activity and energy status during the early postpartum period of high producing dairy cows. Journal of Dairy Science, v.73, n.4, p.938-945, 1990.

STOTT, G. H.; WILLIAMS, R. J. Causes of low brtcdig efficiency in dauy cattle associated with seasonal high temperatures. Journal of Dairy Science, v.45, p.1369-1375, 1969.

STUDER, E. A veterinary perspective of on-farm evaluation of nutrition and reproduction. Journal of Dairy Science, v.81, p.872-876, 1998.

SUTTON, J. D. Altering milk composition by feeding. Journal of Dairy Science, v.72, n.10, p.2801-2814, 1989.

SUTTON, J. D; MORRANT, S. A review of the potential of nutrition to modify milk fat and protein. Livestock Production Science, v.23, p.219-237,1989.

THATCHER, C. D. Effects of nutrition and management of the dry and fresh cow on fertility. Bovine Practitioner, v.21, p.172-179, 1986.

THATCHER, W. W.; COLLIER, R. J. Effects of climate in reproduction. In: MORROW, D. A. (Ed.). Current therapy in theriogenology 2. Philadelphia: W. B. Saunders, 1986. p.301-309.

URIBE, H. A.; KENNEDY, B. W.; MARTIN, S. W. et al. Genetic parameters for common health disorders of Holstein cows. Journal of Dairy Science, v.78, p.421430, 1995. 
VAN DIJK, S.; WENSING, T.; WENTINK, G. et al. Hepatic lipidosis in dairy cows related to health and fertility. In: INT. CONF. PROD. DISEASE FARM ANIM., 7, Ithaca, NY. Proceedings, Cornell Univ., 1989. p.289-292.

VAN DORP, T. E.; DEKKERS, J. C. M.; MARTIN, S. W. et al. Genetic parameters of health disorders, and relationships with 305-day milk yield and conformation traits of registered Holstein cows. Journal of Dairy Science, v.81, p.2264-2270. 1998.

VAN SAUN, R. J. Dry cow nutrition: the key to improving fresh cow performance. Veterinary clinics of north america: food animal practice. Philadelphia: Saunders, 1991. v.7, 599p.

VAN WERVEN, T.; SCHUKKEN, Y. H.; LLOYD, J. et al. The effects of duration of retained placenta on reproduction, milk production, postpartum disease and culling rate. Theriogenolgy, v.37, p.1191-1203, 1992.

VASCONCELOS, J. L. M.; BUNGERT, K. A.; TSAI, S. J. et al. Acute reduction in serum progesterone concentrations due to feed intake. Journal of Dairy Science, v.81, suppl.1, p.226, 1998.

VEENHUIZEN, J. J.; DRACKLEY, J. K.; RICHARD, M. J. et al. Metabolic changes in blood and liver during development and early treatment of experimental fatty liver and ketosis in cows. Journal of Dairy Science, v.74, n.12, p.4238-4253, 1991.

WALTNER, S. S.; MCNAMARA, J. P.; HILLERS, J. K. Relationships of body condition score to production variables in high producing Holstein dairy cattle. Journal of Dairy Science, v.76, p.3410-3419, 1993.

WEAVER, L. D. Managing BCS to maximiza milk yield and reproduction. In: ANNUAL CONVENTION AMERICAN ASSOCIATION OF BOVINE PRACTIONERS, 24., Orlando, 1991. Proceedings. Orlando: AABP, 1991. p.92.

WEST, J. W.; MULLINIX, B. G.; SANDIFER, T. G. Effects of bovine somatotropin on physiologic responses of lactating Holstein and Jersey cows during hot, humid weather. Journal of Dairy Science, v.74, p.840-851, 1991.

WHITLOCK, R. H. Diseases of the abomasum associated with current feeding practices. Journal of the American Veterinary Medical Association, v.154, p.1203, 1969.

WILDMAN, E. E.; JONES, G. M.; WAGNER, P. E. et al. A dairy cow body condition scoring system and its relationship to selected production characteristics. Journal of Dairy Science, v.65, p.495-501, 1982.

WILSON, S. J.; MARION, R. S.; SPAIN, J. N. et al. Effects of a controlled heat stress on ovarian function of dairy cattle. 1. Lactating cows. Journal of Dairy Science, v.81, p.2124-2131, 1998a.

WILSON, S. J.; KIRBY, C. J.; KOENIGSFELD, A. T. et al. Effects of controlled heat stress on ovarian functionof dairy cattle. 2. Heifers. Journal of Dairy Science, v.81, p.2132-2138, 1998b. 
WOLFENSON, D.; ROTH, Z.; MEIDAN, R. Impaired reproduction in heat stressed cattle: basic and applied aspects. Animal Reproduction Science, v.61, p.535-547, 2000.

WOLFENSON, D.; THATCHER, W. W.; BADINGA, L. et al. Effect of heat stress on follicular development during the estrous cycle in lactating dairy cattle. Biology Reproduction, v.52, p.1106-1113, 1995.

YOUNAS, M.; FUQUAY, J. W.; SMITH, A. E. et al. Estrous and endocrine responses of lactating Holsteins to forced ventilation during summer. Journal of Dairy Science, v.76, p.430-436, 1993.

YOUSEF, M. K. Thermoneutral zone. In: YOUSEF, M. K. (Ed.) Stress physiology in livestock, Boca Raton: CRC Press. 1985. v. 1, p.47-54.

ZAMET, C. N.; COLENBRANDER, V. F.; CALLAHAN, C. J. et al. Variables associated with peripartum traits in dairy cows. 1. Effect of dietary forages and disorders on voluntary intake of feed, body weight and milk yield. Theriogenology, v.11, p.229-243, 1979. 